\title{
The Nontraditional Community College Student: A Phenomenological Approach to the Educational Experience
}

\author{
Alexander D. Tuel \\ West Virginia University
}

Follow this and additional works at: https://researchrepository.wvu.edu/etd

\section{Recommended Citation}

Tuel, Alexander D., "The Nontraditional Community College Student: A Phenomenological Approach to the Educational Experience" (2014). Graduate Theses, Dissertations, and Problem Reports. 295.

https://researchrepository.wvu.edu/etd/295

This Dissertation is protected by copyright and/or related rights. It has been brought to you by the The Research Repository @ WVU with permission from the rights-holder(s). You are free to use this Dissertation in any way that is permitted by the copyright and related rights legislation that applies to your use. For other uses you must obtain permission from the rights-holder(s) directly, unless additional rights are indicated by a Creative Commons license in the record and/ or on the work itself. This Dissertation has been accepted for inclusion in WVU Graduate Theses, Dissertations, and Problem Reports collection by an authorized administrator of The Research Repository @ WVU.

For more information, please contact researchrepository@mail.wvu.edu. 
The Nontraditional Community College Student: A Phenomenological Approach to the Educational Experience

\author{
Alexander D. Tuel \\ Dissertation submitted to the \\ College of Education and Human Services \\ at West Virginia University \\ in partial fulfillment of the requirements for the degree of \\ Doctor of Education \\ in \\ Curriculum and Instruction/Educational Leadership \\ Donna Adair Breault, Ph.D., Chair \\ Malayna Bernstein, Ph.D. \\ Sharon Hayes, Ph.D. \\ Samuel Stack, Ph.D. \\ George Brelsford, Ed.D. \\ Department of Curriculum and Instruction
}

Morgantown, West Virginia

2014

Keywords: community college, nontraditional, phenomenology

Copyright (C2014 Alexander D. Tuel 


\begin{abstract}
The Nontraditional Community College Student: A Phenomenological Approach to the Educational Experience
\end{abstract}

Alexander D. Tuel

Nontraditional students make up a larger population at community colleges than their traditional counterparts making this study a necessity to further explore their experience (American Association of Community Colleges, 2013). To better understand this population, a phenomenological approach was taken with an emphasis on a social constructivism framework. This qualitative study utilized Seidman's (2013) three step interviewing process with the aid of photographs taken by the participants to elicit in-depth interview responses. Moustakas' (1994) modified Stevick-Colaizzi-Keen Method of Analysis of Phenomenological Data was used in this study. Four themes emerged from participant's photographs and interviews: motivation, helpful faculty/staff, external responsibilities, and past educational experiences. Looking through the lens of an individual's educational experience provides a critical understanding of realities that can potentially impact policy. 


\section{Dedication}

I would like to dedicate this project to my wife, Laura, and my son, Hudson (and at the time of writing this dedication, our unborn child). Laura's support throughout this endeavor gave me the strength to push past the various roadblocks that came with completing this study. The countless weekends and vacation time that I spent away from my family was made tolerable through her support of my decision to return to school. To my son, although you cannot understand it quite yet, you have provided an outlet for me to escape work and help concentrate on enjoying family. 


\section{Acknowledgements}

I would like to express my deepest gratitude to my committee members for their support and encouragement throughout this project. However, a special thank you is reserved for my chairperson, Dr. Donna Adair Breault. Her mentoring and guidance was a major attribute to the completion of my dissertation. Dr. Breault was my professor for many courses and the knowledge I took away from her classes has proved invaluable to me. Her willingness to step in as my chairperson was an honor and her decision to keep me on as an advisee salvaged my time of completion. Additionally, I would like to thank the participants in this study: Kathy, Jennifer, Douglas, Debra, Jake, and Roland. Your stories have impacted me on so many levels and have given me a deeper appreciation of the role nontraditional students' play in higher education. 
TABLE OF CONTENTS

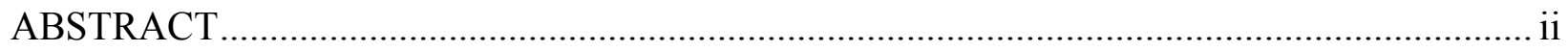

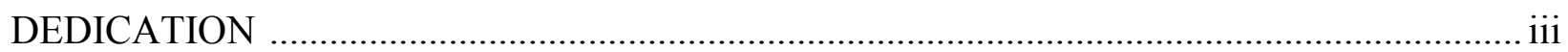

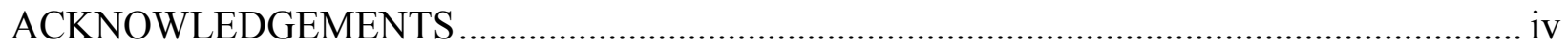

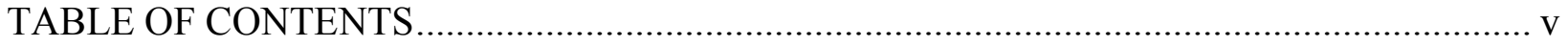

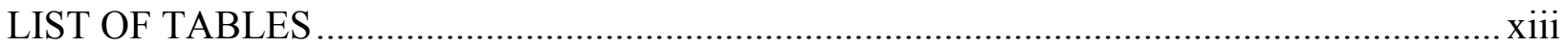

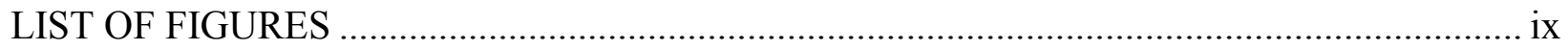

CHAPTER 1: INTRODUCTION ........................................................................................... 1

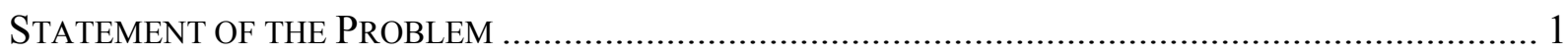

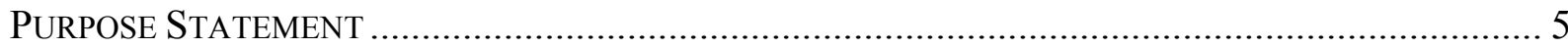

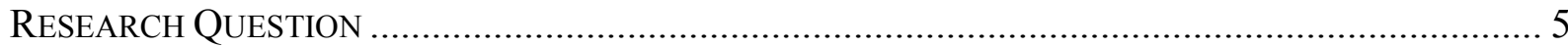

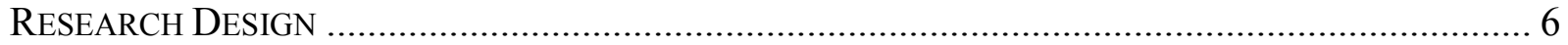

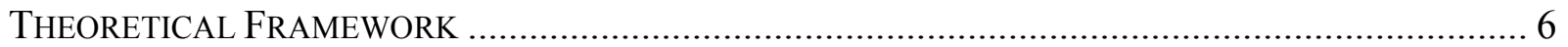

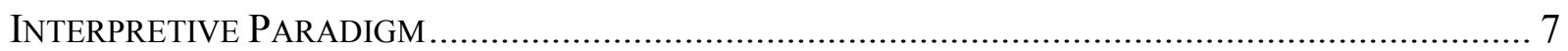

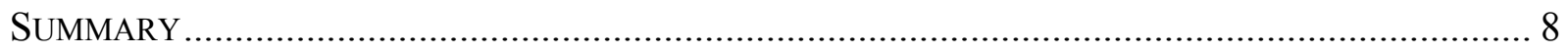

CHAPTER 2: LITERATURE REVIEW ............................................................................ 9

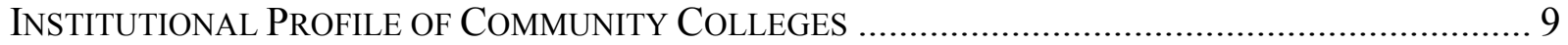

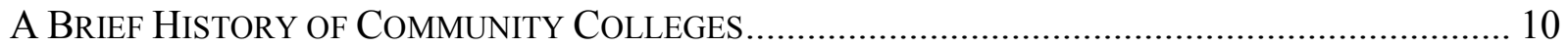

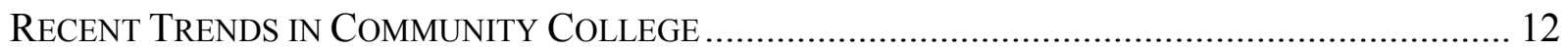

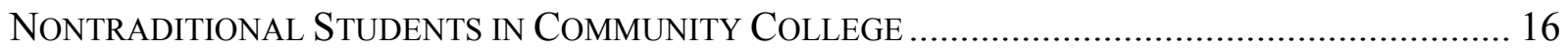

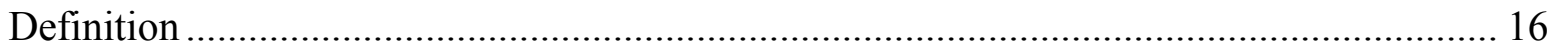

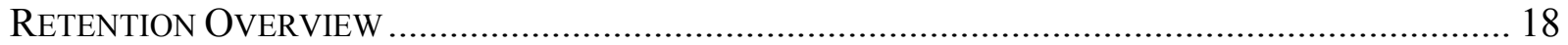

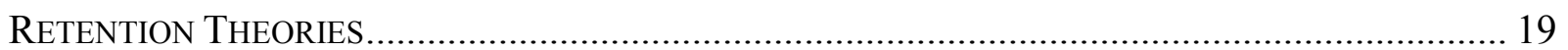

RETENTION IN COMMUNITY COLLEGE ............................................................................ 20

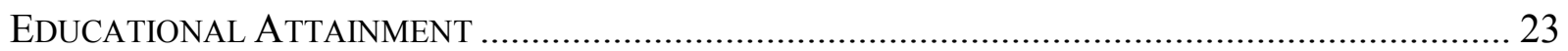

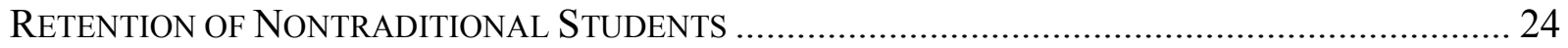

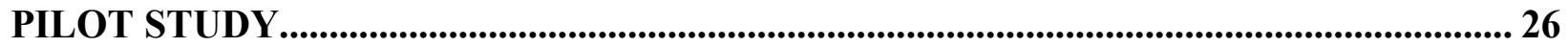

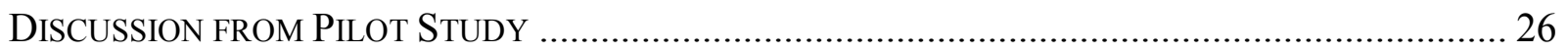

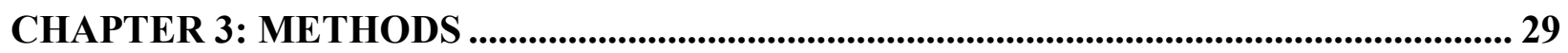

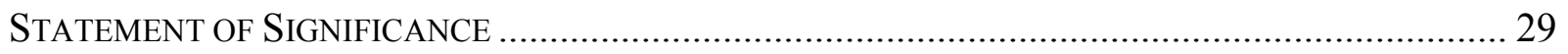

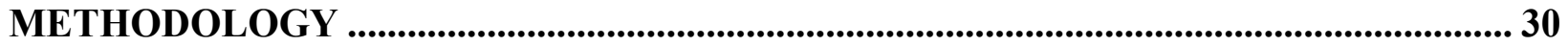

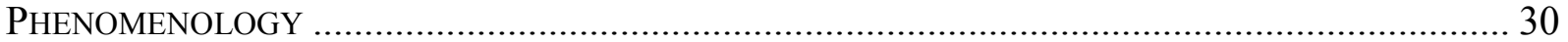

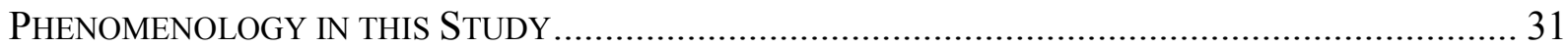

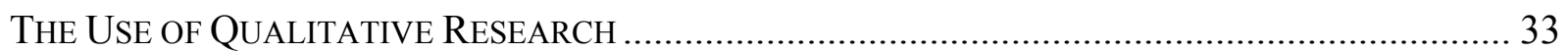

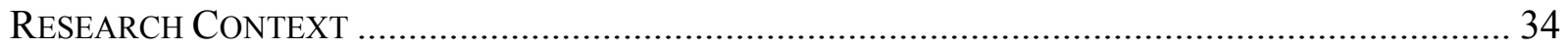

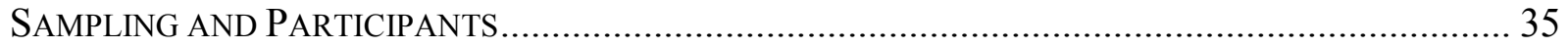

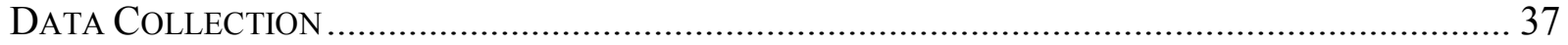




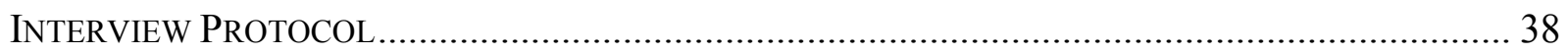

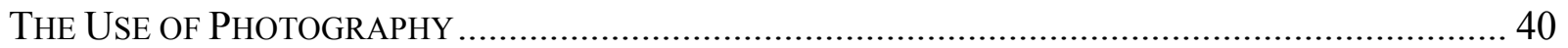

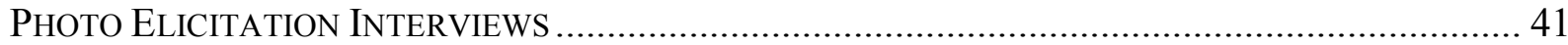

How Photography, PEI's, AND Phenomenology TIE Together ...................................... 42

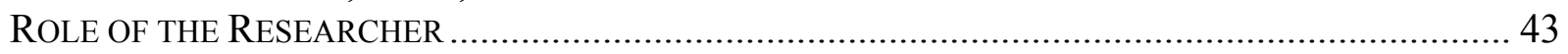

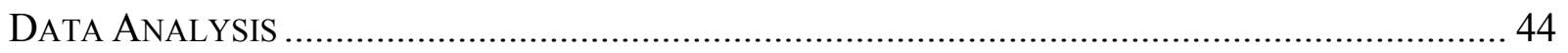

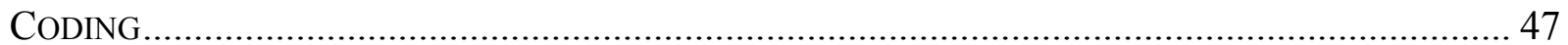

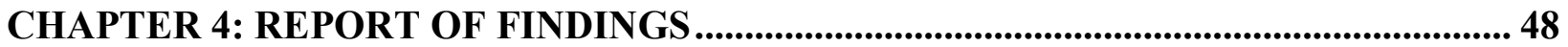

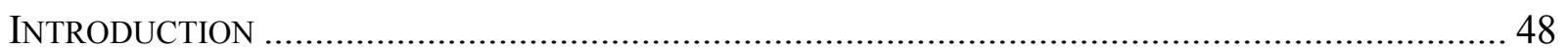

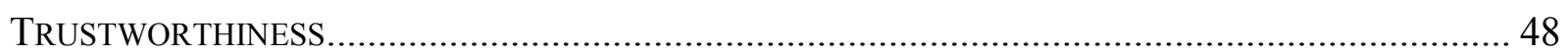

Significant Statements, Themes, TeXtural and Structural Descriptors .................... 49

PARTICIPANT 1: KATHY ........................................................................................................5 50

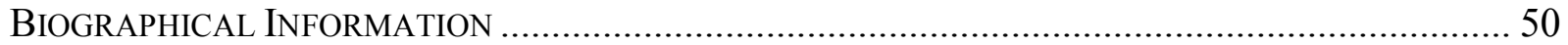

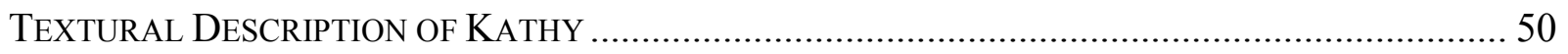

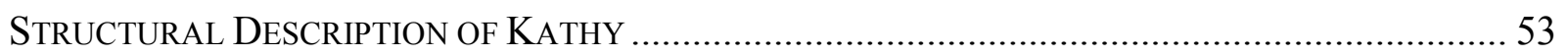

TEXTURAL-STRUCTURAL DESCRIPTION OF KATHY …………………................................ 54

PARTICIPANT 2: JENNIFER .................................................................................................5 59

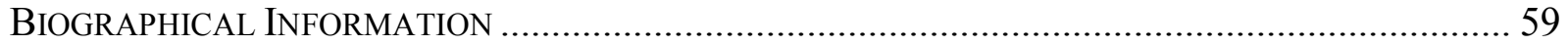

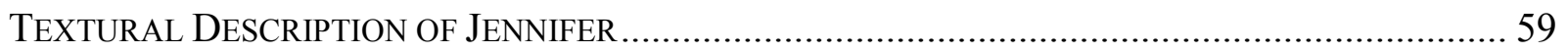

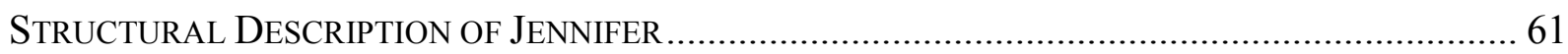

TEXTURAL-STRUCTURAL DESCRIPTION OF JENNIFER ............................................................. 62

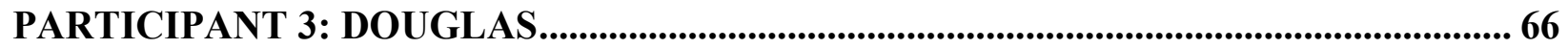

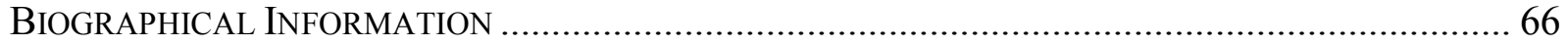

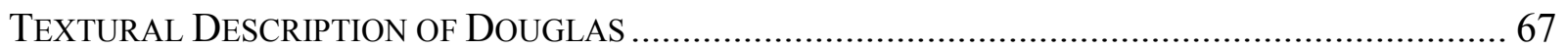

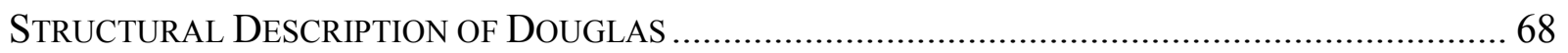

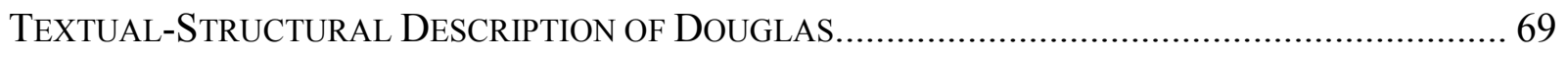

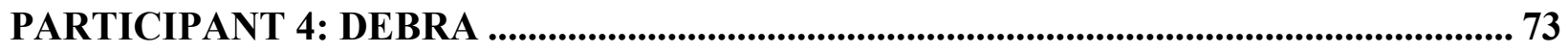

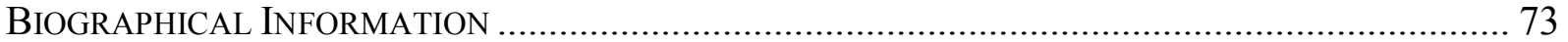

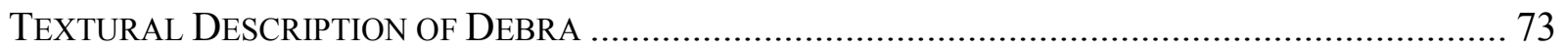

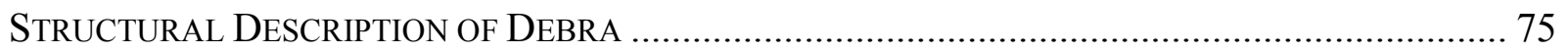

TEXTURAL-STRUCTURAL DESCRIPTION OF DEBRA................................................................. 76

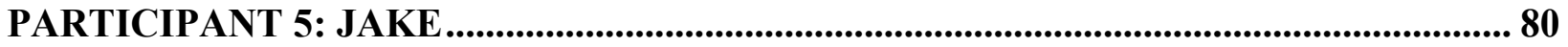

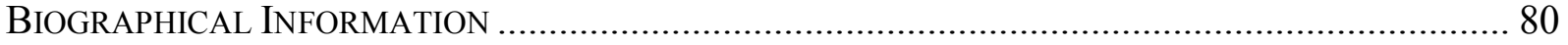

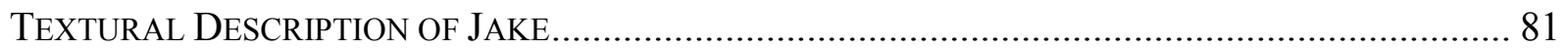

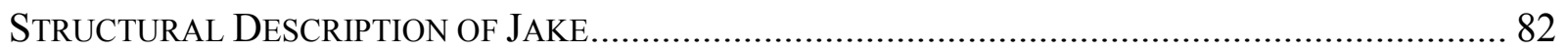

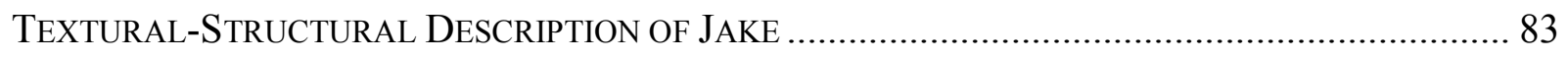

PARTICIPANT 6: ROLAND .......................................................................................................... 87

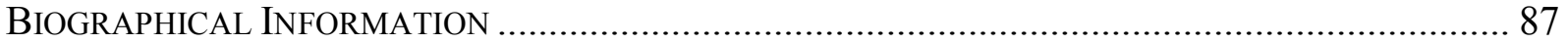

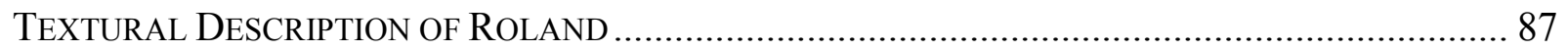

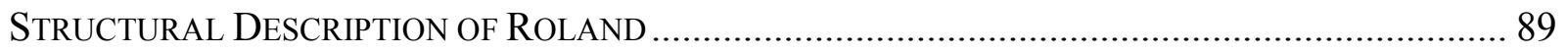




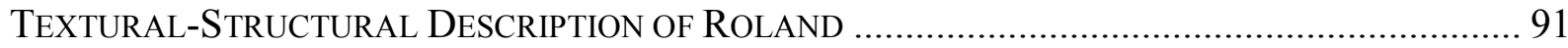

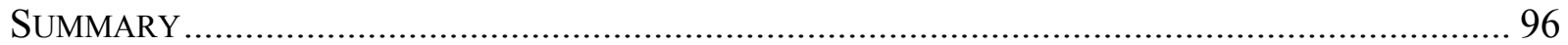

COMPOSITE DESCRIPTION OF THEMES................................................................ 96

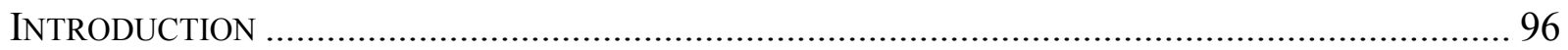

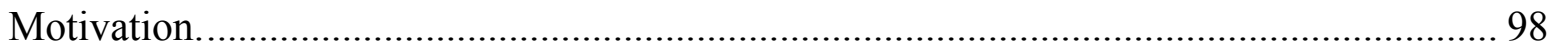

Helpful/Caring Faculty and Staff........................................................................ 99

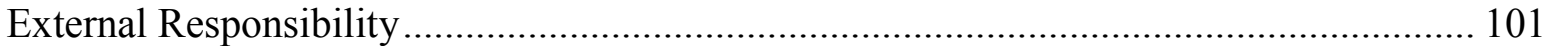

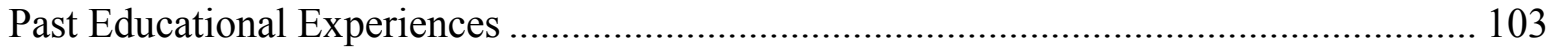

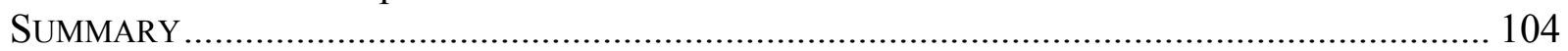

CHAPTER 5: DISCUSSION AND CONCLUSIONS .............................................. 105

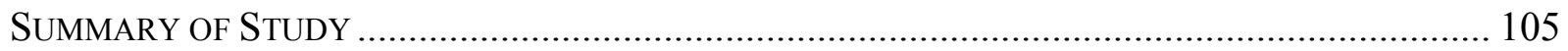

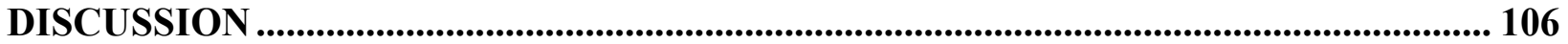

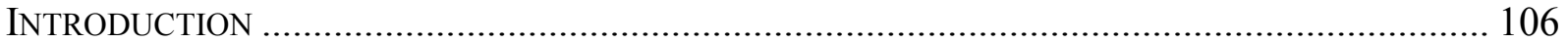

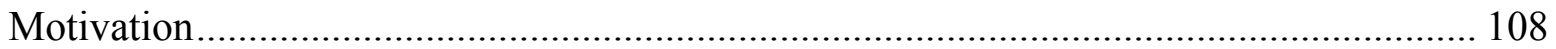

Helpful Faculty and Staff................................................................................... 110

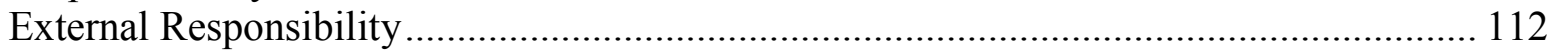

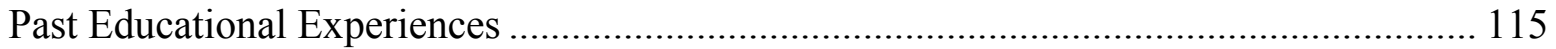

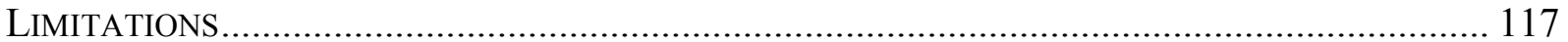

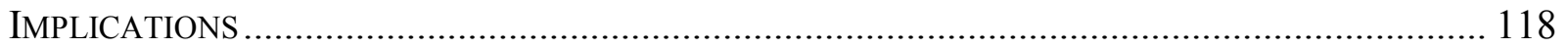

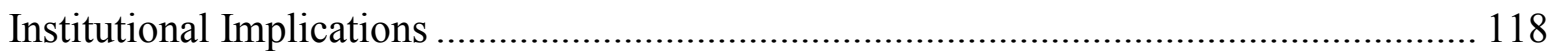

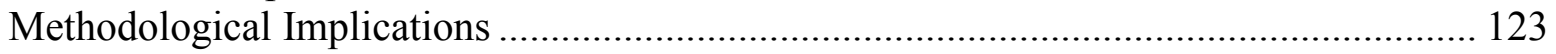

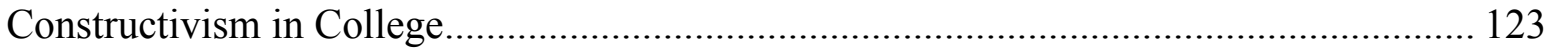

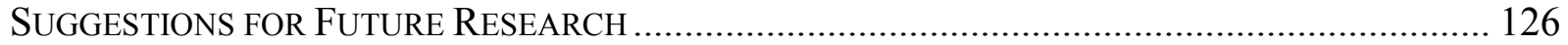

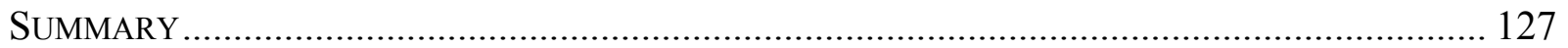

CONCLUSION: THOUGHTS ON THIS EXPERIENCE ............................................................. 128

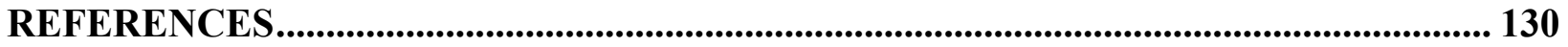

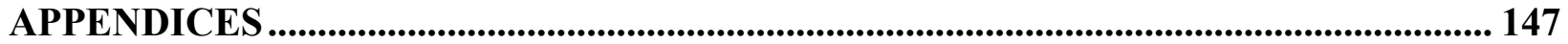

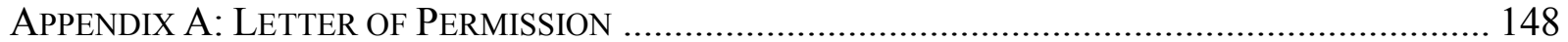

APPENDIX B: COVER LETTER TO PARTICIPANTS ............................................................... 149

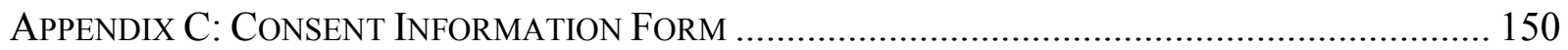

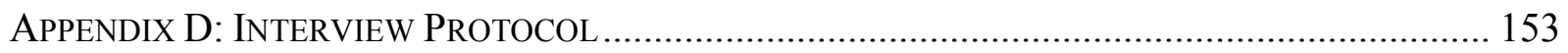

APPENDIX E: PHOTOGRAPHY AND JOURNAL REQUIREMENT .......................................... 155

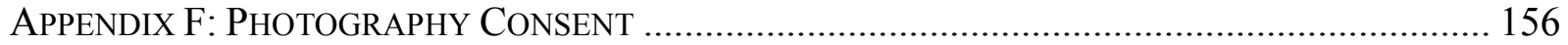

APPENDIX G: Modified STEVICK-COLAIZZI-KeEN METHOd of ANALYSIS OF

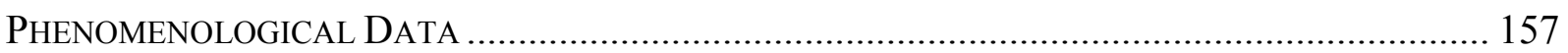

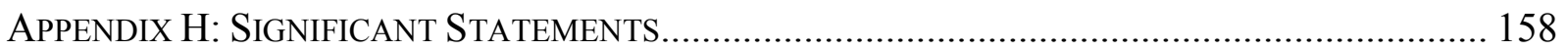




\section{LIST OF TABLES}

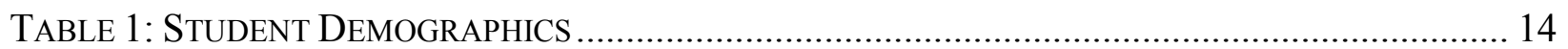

TABLE 2: HeAdCOUNT ENROLLMENT (FALL 2012) ................................................................ 15

TABLE 3: LEVELS Of EDUCATION FOR UNITED STATES RESIDENTS, 25-64 .............................. 23

TABLE 4: PARTICIPANT NONTRAdITIONAL TRAITS .................................................................. 38

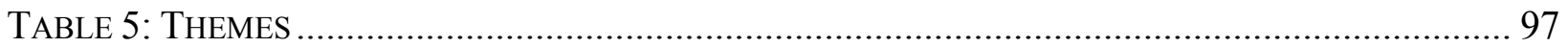




\section{LIST OF FIGURES}

Figure 1. Community College DeParture TheORY .............................................................. 22

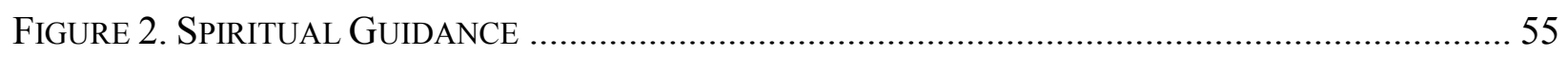

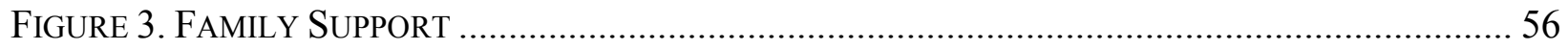

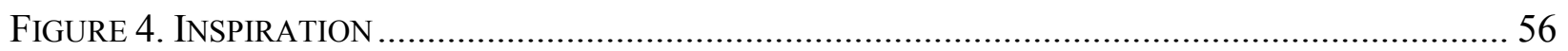

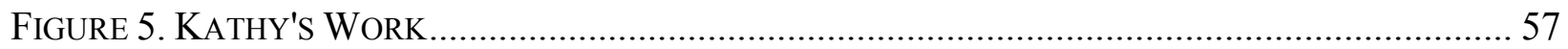

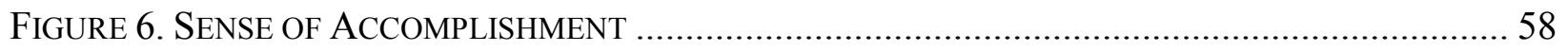

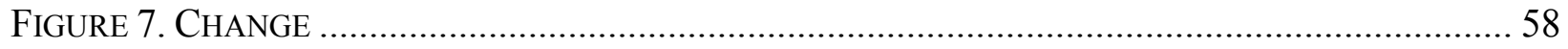

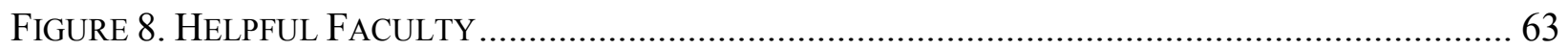

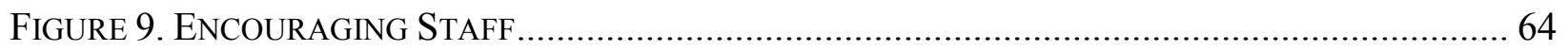

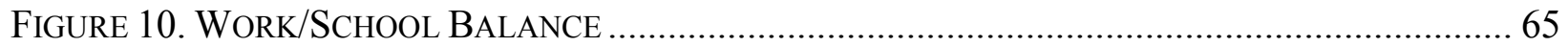

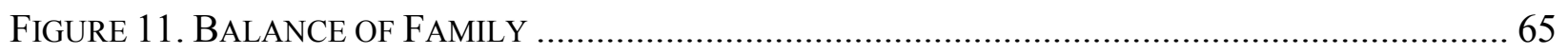

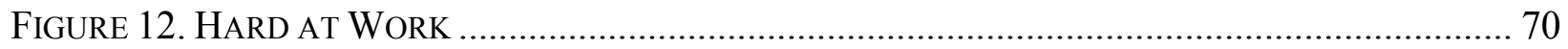

FIGURE 13. PASSION OF WORK ..................................................................................... 70

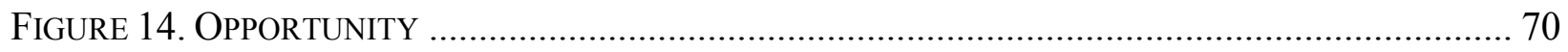

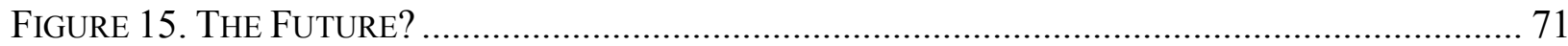

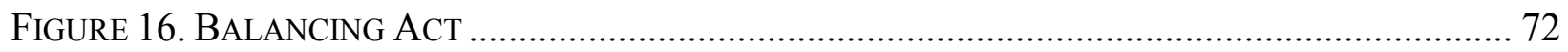

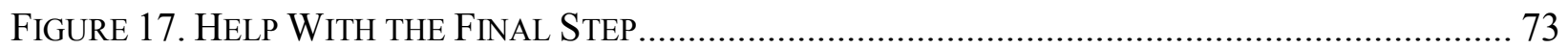

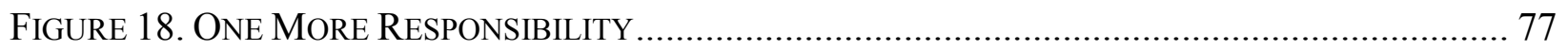

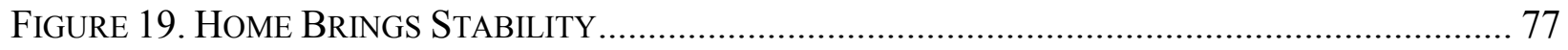

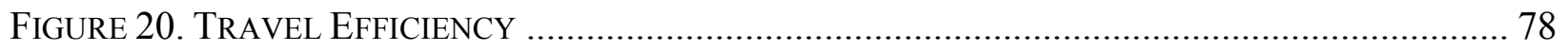

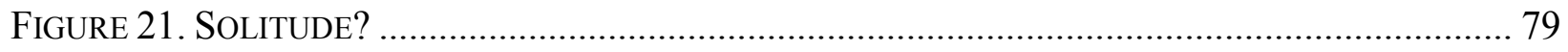

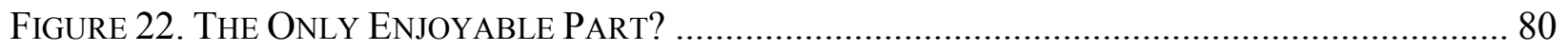




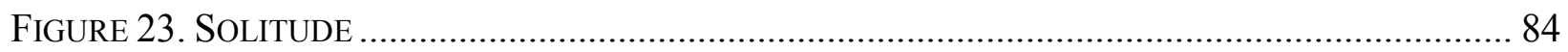

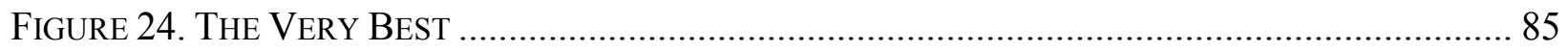

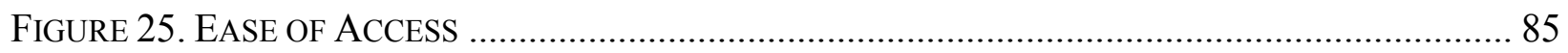

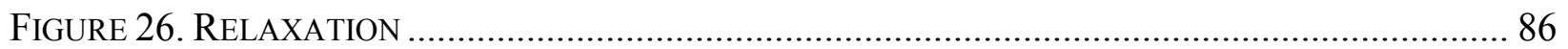

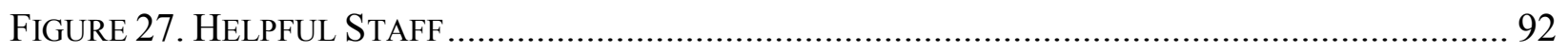

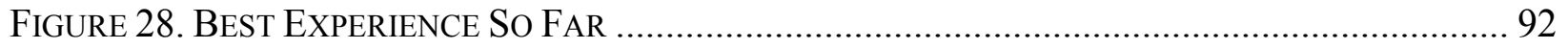

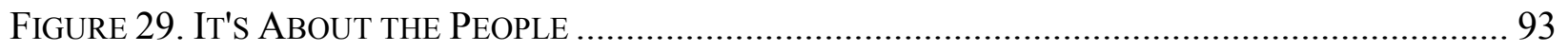

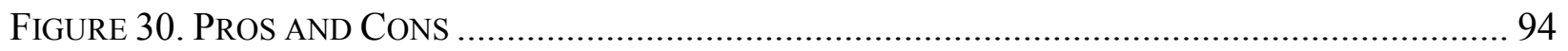

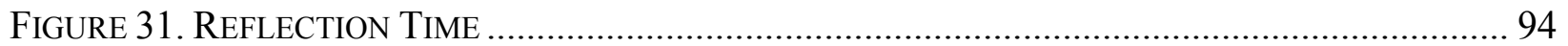

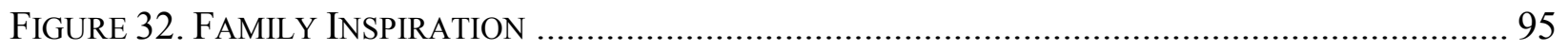




\section{Chapter 1: Introduction}

\section{Statement of the Problem}

Administrators need to find ways to engage in issues that are vital to the success of their institution and student population (Bolman \& Gallos, 2011). One way of reaching this goal is to use the qualitative feedback from certain student demographics. In the case of this dissertation, we will be looking at the input from nontraditional community college students.

Through the use of student input, academic leaders could utilize what Bolman and Gallos (2011a) call reframing. Reframing is the "deliberate process of looking at a situation carefully and from multiple perspectives, choosing to be more mindful about the sensemaking process by examining alternative views and explanations" (p. 22). Effective leaders must take into account multiple perspectives to better understand situations so they do not frame every situation around past-learned experiences. The use of qualitative student information can add a new dimension which to view student experiences and as Bolman and Gallos (2011b) state, "sometimes we just need a new perspective - and an opportunity to step back, take stock, and know that we have options" (p. 29).

Past and current trends are pushing more students towards entrance into community colleges: demographic shifts, rising tuition, and workforce training and certifications are just a few examples (Levin, 2007). Not only are community colleges on the rise but there are increased expectations within all sectors of higher education. For example, President Barack Obama's challenge to higher education from his first State of the Union Address called for an additional eight million degrees by 2020 and to have, once again, the highest proportion of college graduates in the world (Kelly \& Schneider, 2012). Debates in policy over the past few 
decades have focused on college access, but more recently the national focus has turned to student success and degree completion (Kelly \& Schneider, 2012). In turn, institutions will need to refocus their efforts towards creating policies and practices that improve degree completion.

Retention is an important issue within colleges and universities--four-year and two-year. An institution's retention rate can influence its ranking and imply higher quality of education (Astin, 1993). Additionally, retention of students is necessary for financial stability, the sustainability of academic programs, and graduation and transfer is a measure of accountability (Fike \& Fike, 2008). Data from the National Center for Higher Education Management Systems (2009) reports that only 30 percent of individuals who begin as full-time students at community college graduate with an AA within three years.

Although community colleges have enjoyed various successes throughout their history, serious contemporary challenges require a new design. At the beginning of the twenty-first century, colleges have low graduation rates and slow rates of progress; approximately 30 percent of first-time, full-time students who enrolled in fall 2007 completed a certificate or associate's degree within 150 percent of the normal time required to complete such a degree (Aud et al., 2012). Radford, Berkner, Wheeless, and Shepherd (2010) report that only around 46 percent of community colleges student who entered college with the goal of earning a degree or certificate have attained that goal. Additionally, within six years of transitioning to college, only slightly more than one-third of community college entrants complete a credential of any kind (Bailey, Calcagno, Jenkins, Leinbach, \& Kienzl, 2006). Although the open-door policy is a cornerstone of community colleges, it is, unfortunately, due to high attrition rates that Roueche and Hurlburt (1968) state, "it is precisely this enormous attrition rate that had led critics to refer cynically to the open door as a revolving door" (p. 455). 
The literature on postsecondary education provides no single definition of the term "nontraditional student," nor is there agreement on whether such a discernible group exists. Nontraditional demographics can include the following: rural, urban, employed, unemployed, male, female, black, white, Hispanic, married, unmarried, father, mother, rich or poor. They are more diverse than younger students in their motivations, needs, expectations, and experiences of higher education.

Improving student outcomes is a valuable task, not only for the improvement of students' goals, but also for the betterment of higher education. The National Center for Educational Statistics (NCES) uses the following characteristics to identify nontraditional students: (1) delayed enrollment; (2) attends part time; (3) is considered financially independent; (4) works full-time; (5) has dependents other than a spouse (usually children, but sometimes others); (6) is a single parent (either not married or married but separated and has dependents); (7) does not have a high school diploma. According to Choy (2002), those with two or three traits mentioned above are considered moderately nontraditional and those with four or more are considered highly nontraditional.

Yet, Choy's (2002) study found that the "traditional" student might in fact be nontraditional. For example, three-quarters of all postsecondary students had at least one nontraditional characteristic (Choy, 2002); with the majority of those considered highly nontraditional being concentrated in public 2-year institutions.

Levin (2003) views the nontraditional community college student as a group beyond the margins. Levin (2003) uses the term "beyond the margins" to reference a student population outside of the traditional credit students and from students historically marginalized, such as minorities. Bowl (2001) states that there is a "need for institutional change if nontraditional 
students are to thrive within a system that purports to be directed toward widening participation" (p. 141). Bowl (2001) goes as far as to state that for nontraditional students, college can be "isolating and traumatic" (p. 143). Moreover, the lack of change and willingness to improve nontraditional student conditions can frustrate many students (Bowl, 2001). Yet, the history of community colleges has been surrounded by change from responses to social, political and internal transformations (Foote, 1998). This historical trend may continue into the $21^{\text {st }}$ century and assistants towards nontraditional students in their educational pursuits should be a focal point.

The capability for an institution to change and adapt to improve the educational experience of nontraditional students should be a core value of the institution. Levin (1998) has stated that the core of the community college is in its identity and its ability to change to various stimuli. Thus, a community colleges' ability to respond to stimuli, external and internal, helps maintain its identity. "Community colleges make and remake themselves" (Levin, 1998, p. 2) and the ability to adhere to the educational needs of nontraditional students should be no different.

The community college in the United States has experienced resurgence in the past few years, thanks in part to the current Administration's national focus on this educational institution. Community colleges have been described as the most important higher education innovation of the twentieth century (Witt, Wattenbarger, Gollattscheck, \& Suppiger, 1994) and Pascarella and Terenzin (1998) see community colleges as having a major influence on the national system of postsecondary education. With an explosion of student enrollment and a dramatic increase in the number of colleges throughout the country, it is imperative the continuation of studying these institutions to better understand their roles in society. Through further investigation into the 
educational experiences of the nontraditional student population, it is the intention of this study to gain insight to their lives to help policy support their educational goals.

\section{Purpose Statement}

With nontraditional students growing in numbers within community colleges, the purpose of this study is to explore and give a voice to the lived experiences of nontraditional community college students in relation to their education. Exploring how nontraditional community college students experience education with influences from various factors (e.g., academics, social, and personal) will provide a deeper understanding of their lifeworld - "the world of the natural attitude of everyday life" (van Manen, 1997, p. 7). Additionally, how might institutions use their perspectives in conjunction with other research to modify curriculum and programming to retain this student population?

\section{Research Question}

The goal of this study is to discover how degree seeking, moderate to high nontraditional community college students experience education. In their study of community college and students, Levin and Montero-Hernandez (2009), defined educational experience as the "set of academic and social activities in which traditional and nontraditional students participate as long as they are in enrolled in the institution" (p. 27-28). Although I agree with Levin and MonteroHernandez's (2009) definition of educational experience, for the purpose of this study educational experience will also include activities that occur outside of campus life (e.g., family, work, and other external responsibilities). The research question that will guide the collection and analysis of this research is: What is the educational experience of nontraditional students in community college? Participants will be interviewed using Seidman's (2013) three-step process. 


\section{Research Design}

This study will be rooted in phenomenology and according to van Manen (1997), this style of research always sets out to inquire the way we experience the world. The researcher is taking the position that a thick, rich exploration of the lived experience of nontraditional students in community college will provide a better understanding of their education. In a

phenomenological study, the goal is to transform lived experiences into a textural expression of its essence, to have a reflexive awareness (van Manen, 1997).

Phenomenology sets out to "humanize human life" (van Manen, 1997, p. 21) and the intention of this study is for both the researcher and participants to learn something about themselves and their experiences in college. Furthermore, in the framework of phenomenology, the researcher will be open to the experience to have an impact on his outlook on nontraditional students, to challenge his thinking, to extend his traditional way of thinking, and reveal aspects of human experience that may be new (Josselson, 2013).

\section{Theoretical Framework}

This research study will use a social constructivist lens drawing on students' experience and reflections within community college to understand the educational motivations and how the college can help retain this student population. Allowing participants to create and construct meaning of their experiences within the community college context, allows them the opportunity to voice their individual and collective aspirations and goals.

Abdal-Haqq (1998) defined social constructivism as "individuals constructing knowledge in transaction with the environment and in the process both the individual and the environment are changed" (p. 2). Social constructivism reflects the perspective that knowledge is positioned in social cultural context in which the culture provides the tools necessary for development. 
Oldfather, West, \& White (1999) define social constructivism as “a particular view of knowledge, a view of how we come to know...learning is constructed through interactions with others, which take place within a specific socio-cultural context" (p. 8). In this case, this study is looking at how students construct their educational experiences within a specific community college setting.

Interaction with experience is the cornerstone of constructivism (Merriam \& Caffarella, 1999). Crotty (1998) describes constructivism as "the individual human subject engaging with objects in the world and making sense of them" (p. 79). Furthermore, Walker (1995) describes constructivism as the "process of encountering new experiences and applying reflective interpretations within social contexts, with the individual learning and coming to know (p. 2). Hill (2005) posits that constructivism provides a path to "new possibilities of being and doing" (p. 574).

This framework mirrors phenomenology in the shared lens of providing participants the opportunity to be active creators (constructors) of knowledge and meaning. Participants experience their education through dialogue with the researcher, reflection, and sharing their thoughts, and through this process of inquiry, knowledge and meaning is created.

\section{Interpretive Paradigm}

A paradigm represents a view of reality that is grounded in a set of core expectations about world views (Putnam, 1982). In regards to the interpretive paradigm, the core is the necessity of the reflective and intersubjective nature of human experience (Prus, 1990). Constructivism, within an interpretive paradigm, recognizes "multiple socially constructed realities" (Kerka, 2005, p. 555) and attempts to explain the social world directly from the actors 
involved. Additionally, within the realm of phenomenology, the interpretive paradigm focuses on the intra- and intersubjective consciousness of individuals (Putnam, 1982).

Kerka (2005) posits that constructivist inquiry can change both researcher and subject. The interpretive lens will provide opportunities for participants to share their knowledge, their views on education, and their identity within the college environment. Yet, as mentioned previously, this study is meant to have an impact not only the participants but on the research as well.

\section{Summary}

Using a phenomenological approach and a social constructivist framework, this study explores the lived educational experience of six nontraditional community college students. The intention of this paper is to provide a voice to a subpopulation of students into the on-going national dialogue and to senior level college administrators.

Chapter Two reviews current and past literature on community colleges and nontraditional students. 


\section{Chapter 2: Literature Review}

\section{Institutional Profile of Community Colleges}

The number of community colleges increased from 896 to 1,045, between 1974-75 and 2006-07, enrolling 6.2 million students (Provasnik \& Planty, 2008). Of the nearly 18 million undergraduate students enrolled in fall 2009, 40 percent attended public 2-year institutions; helping to prepare millions of students for careers and for transfer to baccalaureate institutions (Aud et al., 2011).

With diverse missions, the community college is able to serve a larger sector of the local population than any other post-secondary institution. Regardless of educational background, family status, or financial means community college provides the opportunity for individuals to advance their education and careers (Laanan, 2000). For example, in 2003, the community colleges in thirteen states enrolled 6 percent or more of the population aged eighteen to fortyfour, up from nine states in 1999 (Cohen \& Brawer, 2008a). Enrollment increased from over five hundred thousand in the early 1960s to over six million by 2005 (Snyder, Dillow, \& Hoffman, 2007). The American Association of Community Colleges (AACC, 2012a) reported the demographics of community college students consists of a higher percentage of women (57\%) than men (43\%), minorities totaled nearly $50 \%$, and the average age was 28 . The AACC (2012b) found that Fall 2009 enrollment showed a higher percentage of students enrolled in credit bearing courses $(61.5 \%)$ compared to noncredit $(34.5 \%)$, as well as a higher percentage of students enrolled part-time (58\%) as compared to full-time (42\%). Additionally, the number of part-time students increased between 1980 and today can be attributed to various factors: an increase in the number of students combining work and study; and an increase in the number of 
reverse transfers (Cohen \& Brawer, 2008b). According to Townsend and Dever (1999) reverse transfer students can fall into two categories: (1) students who begin their postsecondary education at a four-year school then transfer to a two-year school or (2) temporary reverse transfer students, those who attend a two-year college to earn a few credits that can be transferred back to their original institution.

\section{A Brief History of Community Colleges}

Since its inception the community college has developed an assorted set of missions. These missions have ranged from the interests of local residents, businesses, and state and regional economies to vocational training and adult continuing education. However, it did not begin this way; and to better understand the current role and future possibilities of the community college, it is important to get a sense of its history.

During the late $19^{\text {th }}$ century, William Rainey Harper, founding president of the University of Chicago developed a plan to separate the first two years of college from the second two years (Kane \& Rouse, 1999). Several nineteenth and early twentieth century educators wanted the universities to abandon their freshmen and sophomore classes and relegate the function of teaching lower level students to a new set of institutions, to be called junior colleges. Proposals that the junior college should relieve the university of the burden of providing general education for young people were made in 1851 (Cohen \& Brawer, 2008). Although the state universities pushed the founding of community colleges to expand college opportunity, they also wanted to keep the universities academically selective by channeling less able students toward the community colleges (Dougherty, 2003).

Although there were multiple social forces that contributed to the rise of community colleges, one of the more prominent was the need for workers to be trained to help operate the 
nation's expanding industries (Cohen \& Brawer, 2008). Additionally, educational reformers wanted to make the American educational system more rational, efficient, and accommodating to the growing number of high school graduates who would be looking for a postsecondary education (Beach, 2011).

The first public institution to be named a junior college in the United States was Joliet Junior College in Illinois, which was created in 1901, and spear headed by William Rainey Harper, president of the University of Chicago (Beach, 2011). Expansion of junior colleges began after World War II when millions of returning military personnel were given tuition vouchers under the GI Bill. Continued expansion occurred at the end of the Korean War and in the 1960s when the first baby boomers began to reach college (Kane \& Rouse, 1999).

Nevarez and Wood (2010) argued that four social forces contributed to the creation of the community college: interconnectivity of opportunity and education, the German system of education, industrial market needs, and autonomous and localized educational practices. The populist and elitist movements of the late $19^{\text {th }}$ century and early $20^{\text {th }}$, added to the growth of community colleges, but for opposing reasons. The populists strived for equal opportunity among the masses and it could be obtained through education. In contrast, the elitists (comprised mostly of professors and presidents) fought to keep education as an institution meant for the wealthy (Nevarez \& Wood, 2010).

Since their inception up to the 1940s, two-year colleges were commonly known as junior colleges (Cohen \& Brawer, 2008). Originally junior colleges focused on "transfer functions": which consisted of completing two years of a general undergraduate education, earning an associate's degree (AA), and transferring to a four-year college to complete a baccalaureate degree if eligible. Yet, two-year colleges have since that time began to offer vocational 
programs, continuing adult education and workforce development (Kane \& Rouse, 1999).

During the 1950s and 1960s, lower-divisions of private universities used the term junior college, as did those institutions supported by churches or those organized independently. By the 1970s, community college was usually applied to both types (Cohen \& Brawer, 2008).

The development of community colleges offered access to higher education that could not be realized in the selective four-year colleges and universities (Bryant 2001). Brint and Karabel (1989) note that the arrival of the two-year college, in terms of numbers, has had one of the most significant impacts on organizational innovation in the twentieth-century.

In 1947, President Harry Truman, enacted the President's Commission on Higher Education (also known as the Truman Commission). This report made a bold statement in support of vocational education in junior colleges as a means of improving and expanding access. Moreover, the report advocated that junior colleges become an avenue to provide educational access for the vast majority of American youths and adults (Bragg, 2001). Additionally, George F. Zook, future chair of the Truman Commission, argued in 1941, that junior colleges should become "the cultural leaders on a broad front in the communities in which they are located." Zook wanted junior colleges to "represent the highest expression of intellectual, esthetic, and cultural life in the community." Later the Commission sanctioned the notion of and the name community college (Beach, 2011).

\section{Recent Trends in Community College}

Regardless of your educational background, family status, or financial means community college provides the opportunity for all people to advance their education and careers, regardless of their educational background (Laanan, 2000). Cohen (1990) saw community colleges as "the choice not between the local college and a senior residential instituion, but between the local 
college and nothing" (p. 439). Cohen and Brawer (2008) summarized the vital role community colleges have played to a wide array of individuals since its conception to the present day:

The community college reached out to attract those who were not being served by traditional higher education: those who could not afford the tuition; who could not take the time to attend a college full time; whose ethnic background had constrained them from participating; who had inadequate preparation in the lower schools; whose educational process had been interrupted by some temporary condition. (Cohen \& Brawer, 2008, p. 33)

It is through the idea of an open-door institution that individuals attend a community college: personal enrichment, degree seeking, or job skill enhancement. Furthermore, one only needs a high school diploma or GED to gain entrance.

In 2003 , the community colleges in thirteen states enrolled 6 percent or more of the population aged eighteen to forty-four, up from nine states in 1999 (Cohen \& Brawer, 2008a). Enrollment increased from just over five hundred thousand in 1960 to more than two million by 1970, four million by 1980, nearly 5.5 million by the end of the 1990s, and over six million by 2005 (NCES Digest, 2006). Additionally, the rise in the number of part-time students between 1980 and 2002 can be attributed to many factors: the opening of non-campus colleges that enroll few full-timers; an increase in the number of students combining work and study; and an increase in the number of reverse transfers (Cohen \& Brawer, 2008b)

Of the 17.6 million undergraduate students enrolled in degree-granting institutions in fall 2009, 40 percent attended public 2-year institutions (Aud et al., 2011). They have prepared millions of students for careers and for transfer to baccalaureate institutions. Even now, during a time of economic unrest, community colleges have responded to calls for aiding the American 
workforce, training displaced workers, and contributing to the development new industries (American Association of Community Colleges, 2012b).

In 2006-07, there were 1,045 community colleges in the United States, enrolling 6.2 million students (or 35 percent of all postsecondary students enrolled that year). Between 197475 and 2006-07, the number of community colleges in the United States increased by 17 percent, from 896 to 1,045 (Provasnik \& Planty, 2008). Currently, there are 1,132 community colleges in the United States and 45 percent of all first-time freshmen are enrolled in community colleges (The American Association of Community Colleges; AACC; 2012).

Information generated from the National Center for Education Statistic's Integrated Postsecondary Education Data System (IPEDS) Data Center (2012) and the AACC's fast facts (2012) reported that the demographics (see Table 1) of community college students consisted of a higher percentage of women than men, minorities totaled $38 \%$, and the average age was 28 with Whites making up the vast majority of the student population at 51\%. IPEDS (2012) and the AACC (2012) further states that the fall 2012 enrollment showed a higher percentage of students enrolled in credit bearing courses as well as a higher percentage of students enrolled part-time (see Table 2).

Table 1

Student Demographics

\begin{tabular}{lrlrlr}
\hline \multicolumn{1}{c}{ Age } & \multicolumn{2}{c}{ Ethnicity } \\
\hline Average & 28 & Women & Gender & $51 \%$ \\
Median & 23 & Men & $57 \%$ & White & $19 \%$ \\
$18-24$ & $61 \%$ & & $43 \%$ & Hispanic & $14 \%$ \\
$25+$ & $39 \%$ & & Black & Asian/Pacific & $5 \%$ \\
\hline Note: Adapted from IPEDS Data Center, Group Statistics, Fall 2012 and AACC Fast Facts, 2012 & Islander &
\end{tabular}


Table 2

Headcount Enrollment (Fall 2012)

\begin{tabular}{lccccc}
\hline \multicolumn{1}{c}{ By program type } & $\#$ & $\%$ & $\begin{array}{c}\text { By } \\
\text { attendance }\end{array}$ & $\#$ & $\%$ \\
\hline Credit & $8 \mathrm{M}$ & $61.5 \%$ & Part-time & $4.20 \mathrm{M}$ & $61 \%$ \\
Noncredit & $5 \mathrm{M}$ & $39.5 \%$ & Full-time & $2.65 \mathrm{M}$ & $39 \%$ \\
Total & $13 \mathrm{M}$ & & & \\
\hline \multicolumn{7}{l}{ Note: Adapted from IPEDS Data Center, Group Statistics, Fall 2012 and AACC Fast Facts, 2012 } \\
\end{tabular}

During the last four decades, community colleges have seen a large population influx from high school students and an equally large rise in degree attainment. For example, the immediate college enrollment rate of high school completers at the 2-year level, in 1975, was about 18 percent, while 27 percent did so in 2010. Additionally, the number of associate's degrees awarded from academic years $1999-2000$ to $2009-10$ increased by 43 percent for public institutions (from 448,400 to 640,100 degrees). Furthermore, the number of associate's earned by Hispanic students more than doubled from academic years 1999-2000 to 2009-10 (increasing by 118 percent), and the number earned by Black students increased by 89 percent (Aud et al., 2012).

Although community colleges have enjoyed various successes throughout its history, serious contemporary challenges require a new design. At the beginning of the twentieth century, colleges have low graduation rates and slow rates of progress; approximately 30 percent of firsttime, full-time students who enrolled in fall 2007 completed a certificate or associate's degree within 150 percent of the normal time required to complete such a degree (Aud et al., 2012). Poor employment preparation that is inadequately connected to job market needs is an additional problem. And disconnects in transitions between community colleges and baccalaureate institutions also troubles the schools; of the 1.25 million students per year whose initial postsecondary experience is in a community college, at least 350,000 eventually transfer to universities (Cohen, 2008). 
The community college landscape is plagued with lost credits that do not add up to degree attainment. Fewer than half (46\%) of students who enter community colleges with the goal of earning a degree or certificate have attained that goal, transferred to a baccalaureate institution, or are still enrolled 6 years later (Radford et. al, 2010). The rates are lower for Hispanic, Black, Native American, and low-income students. Nearly half of all community college students entering in the fall term drop out before the second fall term begins (ACT, 2010). Whatever the plans of the students, the fact is that community colleges are producing too few graduates to meet workforce needs in several high demand occupations such as mechanics, paralegals, and health professions. According to one study, community colleges produced enough graduates to meet just 51 percent of demand across eight occupations seeking nearly one million new hires in 2009-2010 (ACT, 2012).

\section{Nontraditional Students in Community College}

Definition. The National Center for Higher Education Management Systems (2009) recognized the difficulty in defining nontraditional students based upon their varied demographics. For example, they are more diverse than younger students in their motivations, needs, expectations, and experiences of higher education. This study is in correlation with Richardson and King (1998) who warned of treating nontraditional students as a single homogenous group.

Although we should not treat nontraditional students as a homogenous group, the literature has yielded some common themes. Studies have students 25 years old and older as a key component of a nontraditional student (Bean \& Metzner, 1985; Ely, 1997). Ely (1997) highlights specific needs of students 25 and older. Typically, these students must balance, along with their schoolwork, a variety of issues, such as employment, family, and financial 
responsibilities, making successful completion of their educational objectives more difficult. Variables such as race, income, and prior educational experience have also been considered in nontraditional definitions (Bean \& Metzner, 1985; Rendón, Jalomo, \& Nora, 2000). In a study conducted by Rendón et al. (2000), low income, first-generation status, and employment were the variables taken into consideration.

A study conducted by National Center for Education Statistics (NCES) (Choy, 2002) provided even more variables: (1) delayed enrollment; (2) attends part time; (3) is considered financially independent; (4) works full-time; (5) has dependents other than a spouse (usually children, but sometimes others); (6) is a single parent (either not married or married but separated and has dependents); (7) does not have a high school diploma. Students with two to three traits are considered moderately nontraditional while those with four or more are considered highly nontraditional. Choy (2002) also found that public 2-year institutions have much larger proportions of moderately and highly nontraditional students than 4-year institutions, and much smaller proportions of traditional students.

According to Choy (2002) the highest percentage nontraditional characteristics were in the following order: (1) financially independent, (2) attending part-time, (3) delayed enrollment, (4) worked full-time, (5) had dependents, (6) single parent, and (7) no high school diploma. Additionally, if age, only one of the variables mentioned in the Bean and Metzner (1985) study, was taken into consideration, would account for about 60 percent of the total enrollment of community colleges nationwide in 2009 (AACC, 2012).

The various characteristics of nontraditional students are in contrast to typical traditional college students. For example, traditional students enter college at the age of 18 directly from high school, and usually have families with higher education experience (Laing, Kuo-Ming, \& 
Robinson, 2005). Additionally, Laing et al. (2005) found that traditional students have continuously been in a school setting for three or four years.

Research is beginning to show what we deem "nontraditional" may in fact be "traditional." Ogren (2003) argues that the term nontraditional carries connotations of a population that is new to higher education. Moreover, Choy (2002) found that three-quarters of all postsecondary students had at least one nontraditional characteristic. Additionally, if age (aged 25 and over) were to be the sole determining factor in a study of student demographics, approximately 60 percent of the student population at community college would be considered "nontraditional" (Kim, 2002). With nontraditional becoming the norm across community colleges, continuing to research this population is necessary to the success of retention and degree attainment.

\section{Retention Overview}

Dating back to the 1930s, the first major studies of student retention were conducted by John McNeely. Titled "College Student Mortality," McNeely's (1937) study focused on attrition, degree completion, institutional size, gender, age, and reasons for departure (Cohen \& Bower). Although we still study similar attributes that McNeely examined, today the student population is larger and more diversified, and new retention issues have emerged as well.

By definition, retention is the ability of an institution to successfully graduate the students that initially enroll at a college or university (Berger \& Lyon, 2005). Yet, it should be noted that how student retention is defined for community colleges is different than a four-year university. For example, Wild \& Ebbers (2002) found that most research on retention is based on traditional-age students in the residential settings of universities. Multiple theories and models developed by researchers reveal the aspects, reasons, and patterns of successful progression 
through college and subsequent student attrition, such as levels of preparation, motivations, social integration, institutional compatibility and other individual characteristics (Astin, 1985; Bean \& Metzner, 1985; Spady, 1970; Tinto, 1993).

With various theories available, it is prudent to clarify the vocabulary used within the study of student departure. Berger and Lyon (2005) provide the following definitions:

- Attrition: refers to students who fail to reenroll at an institution in consecutive semesters

- Dropout: refers to a student whose initial educational goal was to complete at least a bachelor's degree but who did not complete it

- Persistence: refers to the desire and action of a student to stay within the system of higher education from beginning year through degree completion

- Mortality: refers to the failure of students to remain in college until graduation

- Stopout: refers to a student who temporarily withdraws from an institution or system

- Withdrawal: refers to the departure of a student from a college or university campus ( $\mathrm{p}$. 7)

\section{Retention Theories}

Spady (1970) highlighted the interaction between student characteristics and key aspects of the campus environment. Wanting to better understand characteristics such as individual interests and attitudes, Spady correlated those attributes to campus variables, such as faculty and administrators; leading him to postulate that if the student and the environment are compatible, the student will adjust both socially and academically, increasing the likelihood of retention.

In 1975, Tinto published a theoretical foundation for research about student retention in higher education. Tinto's model was based on Emilie Durkheim's 1951 book, Suicide: A Study in Sociology. Tinto's (1993) goal was to demonstrate the correlation between the social factors of suicide and the attrition rates of students in college. Tinto (1993) believed that as members of a community (i.e. college), students would interact with their environmental systems: the academic system and social system and in turn lead to persistence. 
Astin's (1984) theory of student involvement referred to the amount of energy that a student dedicates to the academic experience, which can be physical and psychological. He further specifies involvement as one whom devotes energy to studying, time on campus, participation in student organizations, and interaction with faculty members and other students. Astin was sure to note that involvement occurred along a continuum, meaning levels of involvement differ from student to student.

Spady (1970), Tinto (1993), and Astin (1984) originally designed their retention theories with the four-year postsecondary student in mind and focused heavily on social integration. However, it is important to recognize that the typical community college student possesses different characteristics. A main theme in Bean and Metzner's (1985) model was to take into account that nontraditional students were seldom socially integrated into their respected colleges. Other unique nontraditional student variables such as academics, background, and psychological were also taken into account. Interestingly, Bean and Metznter (1985) found that if nontraditional students experience strong environmental support, both on campus from faculty and off from family, the lack of academic support would be negated and a student would persist.

\section{Retention in Community College}

Community colleges during the last decade have come under increased scrutiny with regards to persistence and completion rates (Bailey \& Alfonso, 2005). An institutions' retention rate can influence its ranking and imply higher quality of education (Astin, 1993). Additionally, retention of students is necessary for financial concerns, the sustainability of academic programs, and from the view of public policy makers, graduation and transfer is a measure of accountability (Fike \& Fike, 2008). Braxton, Sullivan, and Johnson (1997) call this national issue the departure puzzle. 
Within six years of transitioning to college, only slightly more than one third of community college entrants complete a credential of any kind (Bailey et al., 2006). Moreover, many students who enroll at community colleges do not intend to earn degrees, so retention varies by type of student and program entrance (Berger \& Lyon, 2005). Data from the National Center for Higher Education Management Systems (2009) reports that fewer than three out of ten students who start community college as full time students graduate with an associate degree in three years.

In a longitudinal study (1983-2011), the ACT (2011) reported that completion trends (graduate in three years or less) in two-year public schools are currently at 28 percent. The highest was reported at 38.8 percent in 1989, and the lowest reported was 25.5 percent in 2010. Although the number is higher than its lowest point in 2010, the current graduation trend is unsatisfactory, at best. The ACT also reported that retention trends (freshmen to sophomore year) are currently at their highest (55.7\%). However, compared to the public four-year institutions (67.6\%), two-year institutions are still behind.

Retention in community colleges needs to be looked at from a different angle than residential college settings. For example, student engagement and integration to the college are typical frameworks in university environments but average community colleges do not fall under this type of setting. Although organizations such as the Integrated Postsecondary Education Data System (IPEDS) have information on community colleges within their data sets, there is little information on the types of institutional practices colleges use to improve retention; the effects of institutional practices on retention are often regulated to surveys (Bailey \& Alfonso, 2004). However, Braxton, Hirschy, and McClendon (2004) developed a theory of student departure specifically for commuter colleges (Figure 1). 


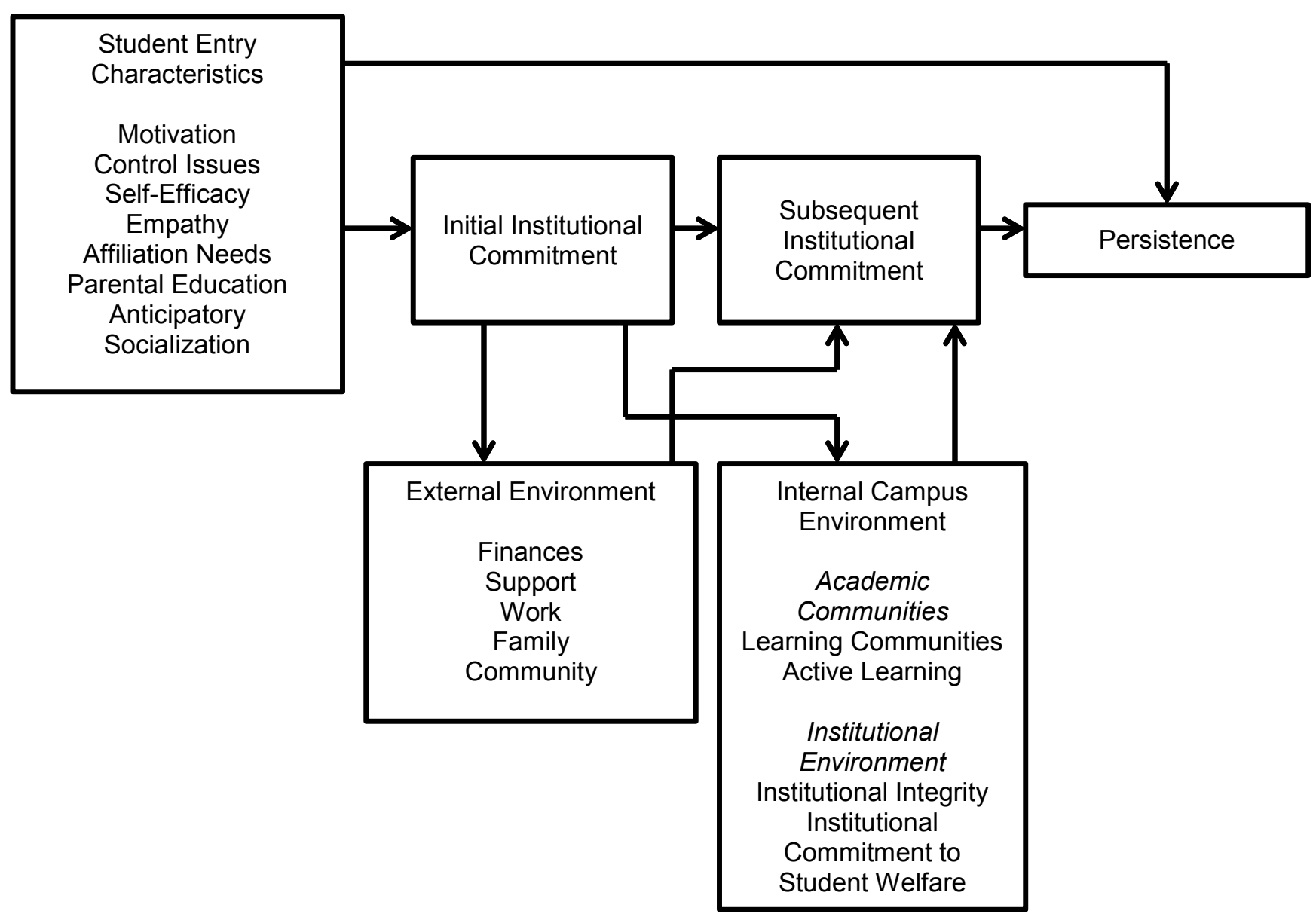

Figure 1. Community college departure theory. Adapted from Understanding and reducing college student departure (p. 43), by Braxton et al., 2004. Adapted with permission.

Although there is an enormous emphasis placed on student retention, it is interesting to note that a study conducted by Habley and McClanahan (2004) revealed that only 40.7 percent of campuses have identified an individual responsible for coordinating retention strategies, 27.2 percent of campuses have established an improvement goal for retention of students from the first to second year, and 19.9 percent of campuses have established a goal for improved degree completion. 


\section{Educational Attainment}

Nontraditional students are more likely than traditional students to leave college without any degree (Choy, 2002). Additionally, compared with traditional students, nontraditional students were more likely to change degree programs, causing prolonged time in college, which increases the likelihood of an individual leaving without a degree (Choy, 2002). In 2011, the percentage of Americans between the ages of 25 and 64 who held a two-or four-year college degree was 38.3 percent (see table 3). In 2009, the rate was 38.1 percent and has risen to 38.7 in 2011 (Lumina Foundation for Education, 2012). Additionally, Pusser et al. (2007) found that the nation's labor force includes 54 million adults who lack a college degree; of those, nearly 34 million have no college experience at all. These numbers present a challenge to the U.S. according to the Georgetown University Center on Education and the Workforce (Carnevale, Smith, \& Strohl, 2010), which predicts that 60 percent of U.S. jobs will require some form of postsecondary education by 2018 .

Table 3

Levels of Education for United States Residents, 25-64

\begin{tabular}{lcc}
\hline Degree Attainment & $\#$ & $\%$ \\
Less than ninth grade & $12,317,606$ & 6.7 \\
Ninth to $12^{\text {th }}$ grade, no diploma & $16,771,699$ & 9.2 \\
High school graduate & $50,600,903$ & 27.6 \\
Some college, no degree & $31,062,111$ & 17.1 \\
Associate degree & $16,016,175$ & 8.7 \\
Bachelor's degree & $36,915,459$ & 20.2 \\
Graduate or professional degree & $19,413,351$ & 10.6 \\
Total & $183,097,304$ & \\
\hline Note: Adapted from the U.S. Census Bureau, 2011 American Community Survey
\end{tabular}

It is clear that there is a correlation between educational attainment and various levels of achievement and prosperity; be it higher income, health, or reduced dependence on governmental assistance. Given the literature and supporting data reports on who attends community colleges 
and the implications for completion, individuals who are considered moderately to highly nontraditional by NCES standards will comprise the nontraditional student population for this study.

\section{Retention of Nontraditional Students}

Choy (2002) postulates that retention needs to be studied in relation to students' goals. This is due to the various reasons nontraditional students attend college. For example, a student may enroll in just a few classes, never intending to obtain a degree. Thus, for this study, only degree-seeking students will be used as participants.

A multitude of factors can have an effect on one's educational experience, be it on campus or off, and one must take these variables into consideration when studying students. Bean and Metzner (1985) understand that nontraditional students should not be viewed through the same lens as traditional students when discussing retention, and they developed a conceptual model specifically tailored to this student population. These scholars identified three variables: academic, environmental, and social. The academic variables include study skills, academic advising, absences, declaration of major, and the availability of courses; while the environmental variables encompass those factors over which the institution has little control but may causes a student to leave the college. Such factors as a lack of finances, working for long hours, lacking encouragement, family responsibilities, and a perceived opportunity to transfer is presumed to have direct effects on students' attrition decisions, as well as indirect effects on dropout through the psychological outcome variables.

Although based in a university setting, Thomas' (2002) studied argued that most institutions cater to traditional student needs. Using social class to underscore how institutional practices affect student retention, Thomas (2002) found that if a student feels that they do not fit 
into the campus environment due to their cultural practices and that their knowledge is undervalued, they might be more inclined to withdraw early.

Socially, an institution can help by promoting social networks: student unions can bring a sense of belonging and feel comfortable and help build networks through team building activities and group work (Thomas, 2002). Social integration refers to the extent to which an individual finds the institution's social environment compatible with his or her own background and preferences (Kuh, Kinzie, Buckley, Bridges, \& Hayek, 2006). The models of Spady (1970) and Tinto (1993) assume that students who have extensive interaction with persons in this social system are more likely to stay enrolled in their college. Measures of social integration typically include the following: students' participation in extracurricular activities, peer friendships on campus, and relationships with faculty. However, Bean and Metzner (1985) found that "social integration is rarely a major factor in attrition decisions at commuter institutions" (p. 520). Additionally, Braxton et al. (2004) view Tinto's (1993) theory of departure, in relation to twoyear colleges, as "undetermined and open to empirical treatment" (p. 17).

Nontraditional students seeking an associate's degree or certificates are more likely than traditional students to leave college without obtaining their goal. Furthermore, they were more likely to drop out their first year of college (Choy, 2002). Rendón (1995) posits that institutions need to focus on two main areas to retain nontraditional students: the transition to college and academic and social integration. However, there are few studies regarding nontraditional students who have persisted past the freshmen year. This study will focus on the experiences of those degree-seeking students who have persisted up to near completion of their degree. Researching their experiences can help an institution discover what factors have aided them to stay with the college and reach their goal. 


\section{Pilot Study}

A pilot study was conducted prior to the dissertation phase. There were numerous benefits to conducting a pilot study for a novice phenomenological researcher, such as myself. For example, the study provided the opportunity to test research instruments (i.e. interviews and the use of photography), the pilot also brought insight to where there were weaknesses in the study and gave the chance to practice data analysis (Simon, 2011). Baker (1994) posits that a sample of size of 10-20 percent of the larger project is an acceptable number of participants for a pilot study. In this case, there were two participants for the pilot study.

\section{Discussion from Pilot Study}

The life stories told by the two participants in the pilot study shed light onto the various elements that play a role in the educational experience. Although limited in scope, the experiences had by Kim and Daniel can help add to the national dialogue of how community colleges can better serve their nontraditional students and, in turn, retain this population.

If nontraditional is now the majority, what are steps to better serve and retain this demographic? From the life stories told by Kim and Daniel, there were three areas that were not readily discussed during their interviews: engagement, mode of delivery, and student services. The vocalized themes are very important in phenomenology, but the unsaid themes should be taken at equal value.

Daniel and Kim discussed, in length, their responsibilities outside of college, and yet rarely mentioned student or faculty interaction. Family, jobs, and the actions required to balance that lifestyle were a major focal point. Wyatt (2011) conducted a study asking how universities successfully engage nontraditional students. What she found was that nontraditional students are not interested in engaging in anything outside the instruction unless it is an event or activity that 
could include their families. According to participants in Wyatt's (2011) study, with all the external factors that play into a nontraditional students' life, it is difficult for an institution to engage these students in the collegiate environment and campus life. Yet, she concluded that engagement with faculty and students in the classroom has the potential to keep nontraditional students active. These findings were additionally supported in a study by Price and Baker (2012) which found class time a more engaging environment for nontraditional students.

External variables played a major role in the lives of Kim and Daniel, with the majority of conversations focusing on family and/or work. However, both participants never mentioned any type of professional relationship with fellow students or faculty. Although consistent with other research, the lack of discussion toward peers and faculty may require further inquiry.

Due to many of the variables mentioned by Wyatt (2011) (e.g., work and dependents), the standard path of traditional courses and programs often do not transcend to nontraditional students (Diamond, 2008). Diamond (2008) posits that nontraditional students generally seek out convenient access. This was consistent with Daniel's experience at college. He took multiple pictures of his time at home while working through the college's online system. However, the college has very few online courses, which does not supply the convenience many nontraditional students desire, and, in turn, often causes students to turn to for-profit institutions (Diamond, 2008). Yet, if the college considers the growth of more online courses, administrators must take into consideration nontraditional student factors. For example, Rovai (2003) developed a composite persistence model for online courses and nontraditional students that took into account factors prior to admission, student characteristics, and internal and external factors.

During each interview the notion of student services (e.g., career services, financial aid, admissions, and library) was rarely mentioned. Kim discussed the use of the library, but to only 
used this space to escape rowdy students and to speak about her inability to navigate the library's electronic files. Daniel never mentioned the library, career service, or admissions, and financial aid was only mentioned in relation to his need for this assistance to help with everyday life.

Daniel and Kim's experiences were primarily external in nature. Bauman et al. (2004) conducted a study, which focused on the benefits of external family and social supports that nontraditional students receive. Their study set out to gather information about nontraditional students in order to better understand the counseling needs of those students. Their participants indicated that they would be likely or very likely to use career-counseling services $(76 \%)$, stress management workshops (57\%), financial aid workshops (53\%), orientation for nontraditional students (53\%), study skills workshop (45\%), and financial assistance with child care (40\%). With career concerns being the most cited reason for returning to school, it was not surprising that they indicated being most likely to use career counseling services. These finding suggests that promoting increased availability of career counseling services may be one way to respond to the specific needs of nontraditional students.

These findings have given me an opportunity to explore a small sample of the nontraditional student population. Daniel and Kim's experiences have opened the door for me to better understand the multitude of variables this population goes through to obtain their educational goals. This experience has laid the foundation for my dissertation and has helped shed some insight into the life-world of nontraditional students. 


\section{Chapter 3: Methods}

\section{Statement of Significance}

My current and past experiences have led me to further investigate issues within community colleges. During my four years working as an entry-level administrator, faculty member, and advisor, I have dealt with various issues regarding students. Issues have ranged from time for childcare, the choice to pay for courses or car repair, the balance between a fulltime job and college, and tragic events such as a house burning down. These experiences have exposed me to numerous subjects such as retention, curriculum offerings, and flexibility.

During my time in post-secondary education I have been a part of numerous committees, giving me an inside look into administrative decision making, which ultimately affects students. To gain a different perspective, academic leaders may better understand their student population through the lens of the students themselves. Decision making, especially related to retention, should not be delegated to other administrators, who may or may not consider student perceptions. Yet, administrators need to find ways to engage in issues that are vital to the success of their institution and student population (Bolman \& Gallos, 2011).

Chao and Good (2004), recognizing a gap in nontraditional student studies, believed proper counseling of these students should begin "by listening to students' firsthand experiences" (p. 5). Luzzo (1999) further states there is a lack of focus on nontraditional student needs due to college and university career programs having catered to the needs of students considered traditional (ages 18-24). Thus, the purpose of this study is to explore the lived educational experience of nontraditional community college students. Investigating the lived experience of 
this type of student will provide a deeper understanding of college life as well as the nontraditional students' role in these institutions. In turn, the views brought forth can aid administrators in understanding the needs that are and are not being met by their respective institutions in an attempt to retain this student population.

\section{Methodology}

\section{Phenomenology}

Phenomenology is a methodological approach used to explore the lived experiences of human beings in order to reveal a deeper understanding of those experiences. The aim of a study rooted in phenomenology seeks to capture the essence of an experience, leading the researcher to an understanding of meaning and action (Miles \& Huberman, 1994). Edmund Husserl (1982) posited that pure or transcendental phenomenology would not be established as a "science of matters of fact, but as a science of essences" (p. xx). With this in mind, it is clear that the use of a phenomenological approach will inform this research by capturing the essence of the educational experiences of nontraditional students at community college. However, essence is not a mystical term, but a way for a researcher to covey the description of a phenomenon (van Manen, 1997).

Established from German philosophy (Husserl, 2001), transcendental phenomenology is based on "subjective openness" (Moustakas, 1994, p. 25). By transcendental, Husserl (1990) was describing experiences that may not be given to an individual imminently. In turn, Husserl (1990) wanted to get clarity, see, and come face-to-face with the essence of an experience. Moustakas (1994) believed phenomenology was concerned with wholeness, with examining entities from many angles, and perspectives. Additionally, through reflections on experience, the researcher can be led to other concepts and understandings, helping better understand the 
phenomenon. Moustakas (1994) further states a phenomenological researcher must have a personal interest in the topic in question, and be intimately connected to the phenomenon. This intimacy can "awaken further interest and concerns, and account for our passionate involvement with whatever is being experienced" (Moustakas, 1994, p. 59), with the researchers own thoughts and reflections as a main source of scientific investigation.

According to Denscombe (2003), phenomenology does not set out to prove a certain question. Instead, participants are those who are actively involved in creating and constructing meaning. Each situation is unique to the individual, and they share their experiences with others who interact and share meaning. Denscombe (2003) further states that:

Reflecting the fact that the world as experienced by living humans is something that is created through the way they interpret and give meaning to their experiences, phenomenology rejects the notion that there is one universal reality and accepts, instead, that things can be seen in different ways by different people at different times in different circumstances, and that each alternative version needs to be recognized as being valid in tis own right. (p. 100)

Similarly, Van Manen (1997), noted that phenomenology is not interested so much in how the experience happened, or how often it happened, but rather in the experience itself-how the individual recalls the experience, and how the essence of the experience is described. In other words, van Manen (1997) sees phenomenological questions as those seeking "meaning and significance of certain phenomena" (p. 23), in this case, educational experience.

\section{Phenomenology in this Study}

I intend to use Moustakas' (1994) view of phenomenology to shape this study. As previously mentioned, one must have personal interest in the topic or phenomenon to awaken 
deeper interest. The interest for this study stems from intimate workings with, and knowledge of, community college structure, academic life, and working with nontraditional students. Yet, I do not pretend to understand the lived experiences of these students. Understanding the essence of the educational experiences of nontraditional students might shed light into their diverse backgrounds.

Patton (2002) stated that foundational question in phenomenology is "what is the meaning, structure and essence of the lived experience of this phenomenon for this person or group of people" (p. 104). This foundational question helped me to situate the purpose of my research. The foundational question and the use of phenomenology, fits within my theoretical lens, allowing individuals the opportunity to draw on their experiences to construct the meaning of nontraditional student experiences in community college. Furthermore, the research provides a link to the practice of community college leadership providing an opportunity for nontraditional students to be direct contributors to their educational experience. By using the phenomenological research method in my study I hope to capture how individuals make meaning and the ways in which they experience phenomena through their senses (Patton, 2002).

Through extracting the emergent themes from each participant's story and refining those themes down into an essence of the experience, I intend to provide a world-view of the lived experience of nontraditional students at a community college. Gaining insight to the experiences and perceptions of those we serve is a valuable tool in policy implementation. To serve the diverse community college student population, institutions must remain cognizant of student needs when developing policies, programs, and services. The traditional surveys and exit interviews do not provide the in-depth personal experiences needed to better serve our students. Postsecondary institutions need to "forsake the ordinary and sameness to move toward the 
extraordinary" (Lake, 2010). Forsaking the ordinary (i.e., surveys) to gain insight to the lived educational experience of non-traditional community college students could provide another perspective into student experiences.

\section{The Use of Qualitative Research}

The qualitative researcher's goal is to seek an understanding of peoples' perceptions. Hatch (2002) viewed qualitative research occurring in natural settings, based on participant perspectives, used the researcher as the data collection instrument, and embraced reflextivity.

The study of college experiences range from first-semester perceptions to retention. Yet, many of these studies have been conducted through the use of quantitative methods such as questionnaires and statistical analysis (Fike \& Fike, 2008; Haplin, 1990; Pascarella \& Terenzini, 1980) However, it has become increasingly evident that qualitative research methods are lacking in the study of student retention. Studies that employ qualitative methodologies can provide rich descriptions of student's experiences and are especially appropriate when trying to understand the experiences of unique populations of students in specific contexts, such as nontraditional students (Metzner \& Bean, 1987). Quantitative means do not fully enable students the opportunity to express the various issues that need to be taken into consideration during the development of their perceptions of the college experience (Harrington \& Schibik, 2003). Additionally, student's expectations have deeper meaning than is made apparent using traditional quantitative mean, such as paper and pencil survey (Tinto, 1993). Moreover, Hermanowicz (2006) argued that:

While Tinto's perspective is interactional to the degree it is premised on a postulated fit between students and a college environment, the students 
themselves - the actual people doing the staying or leaving — are hidden from view. That is, their actions are unobserved and their voices are unheard. (p. 23) Harrington and Schibik (2003) further articulate the benefits of using qualitative methods to better understand student experiences stating, "this information is not filtered through some generic survey instrument, but instead is offered in both our students' words and pictures" (p. 37). Additionally, Miller and Glassner (2004) view qualitative research as "an aim to understand and document others' understandings because it provides us with a means for exploring the points of view of our research subjects" (p. 127). Miles and Huberman (1994) see qualitative inquiry as important due to a focus on "natural occurrences" and to gain a handle on "real life" (p. 10).

\section{Research Context}

The setting for this study was a small community college, located in the Middle States accreditation region of the United States. The population of "Small Community College" (SCC) consists of 874 students and 21 full-time faculty members (22 to 1 ratio). According the Carnegie Classification, SCC is considered Associate's-Public Rural-serving Small. The student population consists of $78 \%$ full time and $22 \%$ part time, with Whites making up the majority of the student body (79\%), Black students were the second most represented body at $19 \%$. Traditionally aged students constitute $81 \%$ of the college, with nontraditional aged students only representing $19 \%$. These numbers demonstrate a need to study this underrepresented population and learn more about their experiences.

A letter of invitation was sent to the President of the college to generate interest and permission to conduct the study within his institution (see Appendix A). Once accepted, the President's permission letter was attached to the institutional review board (IRB) application. 
The researcher's university IRB approved the study in the fall of 2013 and the study is on file under the number 1307069574.

\section{Sampling and Participants}

Sampling in qualitative research is purposeful rather than random in nature (Jones, Torres, \& Arminio, 2006). Samples are drawn to reflect "an emphasis on information-rich cases that elicit an in-depth understanding of particular phenomenon" (Jones, Torres, \& Arminio, 2006, p 65). The purposeful sampling strategy to be employed for this study is best described as comprehensive sampling because the entire sample was selected based on the fact that participants met a common set of criteria (Schumacher \& McMillian, 1993). Additionally, (Creswell, 2013) states that the researcher should purposefully select participants that would best help develop an understanding of the phenomenon.

Based off Choy's (2002) nontraditional descriptors SCC has the following characteristics:

- Financially independent: According to financial aid documents, 441 students indicated they were independent

- Attending part-time: Fall 2012 - there were 186 part-time students

- $\quad$ Delayed enrollment: Of the 873 students for Fall 2012, SCC had 303 new students, of these new students 54 had a high school graduation year less than 2012

- Worked full-time: According to the Spring 2012 Community College Survey of Student Engagement (CCSSE) a question asked, "How many hours per week do you spend working for pay?" and an option of "more than 30 hours" - there were 348 students surveyed and 65 marked that answer, approximately $19 \%$ 
- $\quad$ Had dependents: According to FAFSA, SCC had 222 answer yes to supporting children or supporting dependence other than children

- $\quad$ Single parent: Sixty-seven indicated marital status of single and indicated they either support children or other dependents on their FAFSA forms

- No high school diploma: of the 873 students that were enrolled for Fall 2012, SCC had thirty-five with GED's. Five individuals finished their GED after the semester started. Another twenty-six students were admitted conditionally because they had not yet completed their GED or received a high school diploma Eligible participants included students who fell under at least two or more of the NCES's description of nontraditional students, meaning participants were considered moderately to highly nontraditional students. Additional criteria included individuals who are degree seeking and have completed at least $70 \%$ of their program. Near completion was used has a criterion because those students should have developed a sense of the college experience and had exposure to practices that have contributed to their retention.

Each interview was conducted in a small, conference room to ensure confidentiality. The Institutional Research director at SCC was asked to identify students who met Choy’s (2002) nontraditional student criteria. Each potential participant was contacted by the researcher via email (see Appendix B for IRB approved cover letter) and phone and asked to meet face-to-face with the researcher to learn more about the study and their role. During the initial meeting, participants were shown the university approved consent form (see Appendix C) and discussed in detail. 


\section{Data Collection}

Data collection was completed through two instruments: audio-recorded interviews and photography. Seidman's (2013) three-step interview process was implemented to collect participant's experiences (see Appendix D) for interview and follow up questions. Additionally, all interviews were transcribed verbatim. Seidman (2013) states that this structure for in-depth phenomenological interviewing is meant to have the participants "reconstruct his or her experience within the topic under study" (p. 14). It is through this notion that this study attempts to understand the educational experience of the nontraditional participants. It should be noted that a researcher could never truly understand another's thought process. Yet, the goal of these interviews was to come as close as possible to the participants" "subjective point-of-view" (Seidman, 2013, p. 17).

The six participants chosen for this study were given a digital camera to take pictures of their experiences of college over a one-week period. Participants were required take a minimum of 15 pictures to have sufficient information to discuss. The participants were asked to take pictures that illustrate their educational experiences at college, which can include college life (academic engagement, faculty contact, student motivation, career development, financial issues, student values, social integration and involvement, and overall satisfaction) and any other external factors that may have an impact on their college experience (family, work, friends, etc.). Participants were also given a notebook (see Appendix E for journal requirements) to record information related to each photo, including the time, date, primary theme (what the photo meant to them), and the thoughts and feelings the photo elicited for them. 


\section{Interview Protocol}

The interview process followed Seidman's (2013) three-step process. Prior to the beginning of the first interview participants' traits based off Choy (2002) were categorized (see Table 4).

Table 4

Participant Nontraditional Traits

\begin{tabular}{lccccc}
\hline Name & \# of Traits & $\begin{array}{c}\text { Financially } \\
\text { Independent }\end{array}$ & $\begin{array}{c}\text { Has } \\
\text { Dependents }\end{array}$ & $\begin{array}{c}\text { Delayed } \\
\text { Enrollment }\end{array}$ & Part-Time \\
\hline Kathy & 2 & $\mathrm{x}$ & $\mathrm{x}$ & & \\
Jennifer & 4 & $\mathrm{x}$ & $\mathrm{x}$ & $\mathrm{x}$ & $\mathrm{x}$ \\
Douglas & 4 & $\mathrm{x}$ & $\mathrm{x}$ & $\mathrm{x}$ & $\mathrm{x}$ \\
Debra & 3 & $\mathrm{x}$ & $\mathrm{x}$ & $\mathrm{x}$ & \\
Jake & 3 & $\mathrm{x}$ & & $\mathrm{x}$ & $\mathrm{x}$ \\
Roland & 4 & $\mathrm{x}$ & $\mathrm{x}$ & $\mathrm{x}$ & $\mathrm{x}$
\end{tabular}

Additionally, participants were required to sign an informed consent and photography release form (see Appendix F). It should be noted that within the photography consent form if participants took pictures of individuals during the study, they must get said individual to sign the same document allowing the researcher to use their picture. Each interview lasted approximately one hour. The first interview consisted of an explanation of the study and what will be required of the participant's time and efforts. Moreover, in accordance with Seidman's (2013) interview protocol, the first interview required the participants to reflect on their earliest experiences with education prior to attending community college. Reflecting on their education in relationship to family, friends, school, and/or work will helped place their experiences in the context of their own lives. 
The second interview concentrated on the "concrete details of the participants' present lived experience" (Seidman, 2013, p. 21). The goal in this stage of the interview process is to have participants talk about their relationships with fellow students, faculty, staff, administrators, family, employer, and any other facet of the campus and home communities. At the conclusion of the second interview, participants were given cameras to capture their experiences of college on and off campus.

Participants were given one week to take photographs of their educational experiences. The type of camera to be used in this study was digital. The purpose of this style of camera is to allow participants to opportunity to view the pictures they have taken instantly and to reflect on those pictures for journal entries, avoiding prolonged time gaps. In a study by Blinn and Harrist (1991), Polaroid cameras were used to a similar end, allowing subjects immediate feedback. At the conclusion of the one-week period, participants turned the cameras into the researcher. The photographs were downloaded onto the researcher's computer and brought to the final interview for reflection.

The final interview consisted of participants reflecting on the meaning of their educational experience at the community college, with their photographs as a reflection tool. According to Seidman (2013) having participants explore the past experiences that have led them to their current situation and describing details of their current situation allows them the opportunity to reflect on the present state of their lives in the context of their educational experience. The participant produced photographs provided an opportunity to showcase individual self-concept in relation to their experiences. At the conclusion of the interview, the researcher asked the participants to choose one photograph that, above all others, truly captures their educational experience at the community college. 


\section{The Use of Photography}

Photography has been used to capture a variety of experiences and perceptions in the social sciences. For example, Beilin (2005) utilized this method in which she had farmers take photographs of significant landscapes to gain a better understanding of their relationship with the land. Additionally, Campos-Monteiro and Dollinger (1998) employed the use of photography to gain a better understanding of the collective orientation and identity among street children. Photographs are a reflection of the photographer's point of view and biases, giving the photographer the ability to construct their own meaning from/of the photograph (Harper, 2000).

The use of reflexive photography gives the participant the opportunity to capture what they believe to be important. This is a vital research tool because the researcher may not have access or capture certain aspects of the participant's life. Moreover, richer data can be derived from photo-elicitation interviews (PEIs) (which will be discussed in more detail later in the paper) than that of data usually obtained from traditional interviews.

One of the initial questions a researcher must ask is who will take the photographs. Two of the most common answers to this question are researcher-produced and participant-produced photographs. Clark-Ibanez (2004) states that researchers must be cautious to not capture what they perceive as visually interesting, but rather what might be meaningful for the interview participants. However, participant-produced photographs, occasionally called native photography (Blinn \& Harrist, 1991), allow for participants to become an active source of data.

Harper (1998) states that photographs somehow seen as 'truth' are no more than reflections of the photographer's point of view, biases, and knowledge, or lack of knowledge, leading to question the trustworthiness of the captured image. Further arguments against researcher-photographs include, Prosser (1998) and Adelman and Prosser (1998) who believed 
taking pictures make the researcher more visible, making the rapport and inhibiting participant's everyday behavior and that "the photograph is ultimately an extension of the photographer" (Adelman \& Prosser, 1998, p. 148), as opposed to who we are actually studying.

Due to the potential nature of the researcher to take pictures of what he or she may find interesting, I allowed the participants to take their own photographs. Using participant-produced photographs can provide, potentially unattainable (i.e. home life), visually rich material. Researchers may potentially be seen as an outsider and prevent researchers from accessing certain aspects of life (Collier, 1957). Having participant produce photographs safeguarded them form any potential researcher's biasness toward the subject matter in question. This allowed participants an opportunity to freely capture what they perceived as an important experience.

\section{Photo Elicitation Interviews}

Using photographs during interviews (also called photo elicitation interviews) is a process where the researcher is a "listener" and the participant "interprets" (Loeffler, 2004, p. 539). Collier and Collier (1986) support the use of photographs during interviews because they have to potential to "sharpen the memory and give the interview an immediate character of realistic reconstruction" (p. 106). Additionally, Collier and Collier (1986) believe that participants are "relived of the stress of being the subject of the interrogation" (p. 106). This allows the participant to become the expert, leading the researcher through important aspects of the pictures.

Harper (1988) stated that "in the reflexive photographic method, the subject shares in the definition of the meaning; thus, the definitions are said to 'reflect back' from the subject" (p. 6465). Harrington and Schibik (2003) further state that "the use of reflexive photography and the analysis of the resulting photographs and reflexive essays provide students with an opportunity 
to elaborate on the underlying reasons and assumptions behind the development of their opinions and impressions" (p. 24).

Participants tend to analyze photographs in-depth and react to cues present in the images (Harrington \& Schibik, 2003). Harper (1984) explains the connection between photography interviews and phenomenology:

A phenomenological sense is gained as the informant explains what the objects in the photograph mean, where they have come from, and what may be missing. This method provides a way in which the interview can move from the concrete (as represented by the literal objects in the image) to the socially abstract (what the objects in the photograph mean to the individual being interviewed). (p. 21) Harper (2012) describes the use of photography in phenomenological terms, utilizing verstehen; loosely translated as understanding. Embracing verstehen requires, just as in transcendental phenomenology, the researcher to put aside assumptions. Harper (2012) further elaborates, stating that photographs serve as a go-between with the researcher and participant. Additionally, Clark-Ibanez (2004) states, "researchers can use photographs as a tool to expand on questions and simultaneously, participants can use photographs to provide a unique way to communicate dimensions of their lives" (p. 1512).

It is through the use of the journal entries that participants conducted initial analysis of the photographs. During our one-on-one interviews, the journals helped serve as a talking point, but also helped participants recall aspects they may have forgotten or bring forward ideas not originally thought about.

\section{How Photography, PEI's, and Phenomenology Tie Together}


In phenomenology, an individual must start with his or her own first-person experience-seeking to understand what he or she is experiencing and how you are experiencing the phenomena. Husserl (2001) saw this idea as Zu den Sachen selbst, which translates to, get back to things as you actually experience them. Photographs will allow participants to capture their experience as it occurs. Moreover, PEI's will allow participants to opportunity to express their feelings about each experience, opening up a deeper understanding.

Combining photography with phenomenology has been dated back to 1970s. For example, Ziller and Smith (1977) wanted participants to produce photos which show their own unique perceptual orientations and proposed that the "perceiver is perceivable through the photography" (p. 173). Compared to other image mediums (e.g., drawings or paintings) photography can have the ability to bring viewers closer to the phenomena in question (Pettersson, 2011). Additionally, Damisch (1978) states that the use of a camera can "grasp the essence of the phenomenon under consideration by submitting that phenomenon to a series of imaginary variations" (p. 70).

Every student enters post-secondary education with different backgrounds and experiences and gaining insight into these experiences will open up a litany of narratives and new perspectives to help understand the educational experience. The use of photographs allows the researcher/reader to view the experiences through the eyes of the participants (nontraditional students), and can provide a glimpse into spaces, places, and worlds that are often inaccessible to researchers, faculty or administrators (Bloustein \& Baker, 2003).

\section{Role of the Researcher}

For each interview the researcher took minimal notes as to not disrupt the flow of the conversation. However, field notes were added once each individual interview concluded. 
During interviews based in phenomenology, the researcher's role is to facilitate, rather than dictate (Smith \& Osborn, 2003). To this end, following the interview protocol, the researcher listened to each participant and utilized follow-up and exploring questions when certain dialogue warranted such an action. The researcher refrained from any personal comments that influenced the participants' comments on educational experiences.

It should be recognized that during the interviews and sequential findings that I could not fully eliminate my knowledge of nontraditional students and certain educational experiences. Additionally, the fact that I ultimately chose which significant statements to include and how the interview transcripts were written, demonstrates my influence to the stories that eventually unfolded. Yet, acknowledging this partiality should not be seen as any form of contamination on the study, but as recognition that the researcher is aware of the influence placed upon the outcome.

\section{Data Analysis}

My research employed Moustakas' (1994) modified Stevinck-Colaizzi-Keen Method of Analysis of Phenomenological Data. A copy can be found in Appendix G. According to Moustakas (1994), the examination of a lived experience occurs in four steps: 1) epoché, 2) phenomenological reduction, 3) imaginative variation, and 4) synthesis.

The epoché (or bracketing) is the first step in coming to know certain experiences by "setting aside their experiences, as much as possible, to take a fresh perspective toward the phenomenon under examination" (Creswell, 2013, p. 80); only then does the researcher become aware of new understandings. Although difficult to achieve, in this step the researcher's role is to listen without any preconceived notions and allow the participants to become the center of the study. Since the researcher is not, nor has ever been, a nontraditional student, nor has the 
researcher attended a community college; this is not part of my lived experience and could potentially open up the opportunity for new horizons to be explored. Yet, as a college graduate and current doctoral candidate, the researcher can bracket certain college experiences (e.g., fulltime job, family, homework, finding time to study, and financial aid). Beech (1999) requires the researcher to "unknow our own interpretations of similar experiences" (p. 45). This does not mean we forget experiences, but reflect on our own conscious experiences (Beech, 1999). To this end, the researcher will write an account of his own thoughts on the educational experience, reflecting upon them and placed them to one side; which attempts to silence my own thoughts by being cognizant of them (Munhall, 1994).

The second step according to Moustakas (1994) is called phenomenological reduction. This step requires the researcher to provide textural language (the "what" of the experience) from what one sees and experience from various angles. Additionally, horizonalization is a key process of phenomenological reduction. Horizonalization requires every statement to be initially treated as having "equal value, statements irrelevant to the topic as well as those that are repetitive or overlapping are deleted, leaving only the horizons" (Moustakas, 1994, p. 97). For this study, each individual phenomenon was explored in the context of its own horizon. Therefore, the educational experience of each participant has its own horizon to be examined. Imaginative variation is the third step in the research process (Moustakas, 1994). This process involves looking at the phenomenon in question and attempt to discover "how did the experience of the phenomenon come to be what it is?" (Moustakas, 1994, p. 98). At this stage, the researcher uses significant statements to develop a description of the context that influenced "how" the participants experienced the phenomenon (a structural description) (Creswell, 2013). 
The final step in the research process involves taking the textural and structural descriptions and writing a combined description that creates the "essence" of the phenomenon in question. This stage will bring forth common experiences from each participant and allow the reader to better understand what it is like for an individual to experience that phenomenon (Creswell, 2013).

Each interview was transcribed and read multiple times. Attempting to avoid judgment on any comment, epoché was conducted to see the phenomenon in question as a new experience. Beginning with horizonalization, a list of 45 significant statements was generated (see Appendix H) relating to how the participants experienced their education, with every statement treated as new and of equal value. Moustakas (1994) views horizons as adding meaning and providing a clear idea of the situation in question in regards to the participant's thoughts and feelings. In this phase of analysis, no attempt was made to group these statements, the researcher simply wanted to learn how the participants viewed the term, educational experience (Moerer-Urdahl \& Creswell, 2004).

A list of meaning units, or themes, was clustered into four themes with overlapping and repetitive statements removed. A textural description will be developed for participants, followed by the structural description of their essences. The final step will combine the textural and structural descriptions, creating the composite meaning and essence of each nontraditional student's educational experience.

Participants' journal entries and photographs were used during the interview to assist in triangulation. Triangulation helps the researcher look at a phenomenon from more than one source of data, which will help limit personal biases and assisted in elaborating the research (Decrop, 1999). 


\section{Coding}

To effectively organize and code the data for this study, Saldaña's (2012) book The Coding Manual for Qualitative Researchers was utilized. This was the first method used to code all transcripts, participant's journal entries, and researcher's field notes. Although various qualitative coding methods could be applied to a study such as this one (e.g., In Vivo), a themeing code is most appropriate for this study rooted in phenomenology.

Overall a theme is "an extended phrase or sentence that identifies what a unit of data is about and/or what it means" (Saldaña, 2012, p. 175). Additionally, Saldaña, (2012) argues that themes can be found in two identifiable areas: the manifest level (observable information) and at the latent level (underlying the phenomenon). In considering what to theme while analyzing the data, Saldaña, (2012) suggests the following: "repeating ideas, participant or indigenous terms, metaphors and analogies, transitions or shifts in topic, similarities and differences of participants expressions... and even what is missing from - not discussed or present in - the data" (p. 180).

QSR International's NVivo 10 (NVivo, 2012) software package will be used to assist in the management of the interviews, journals, and field notes. This program will help with organizing files, coding, and final analysis. The use of computer-assisted qualitative data analysis software (CAQDAS) will help with the complexity and abundance of information in qualitative research (Sinkovics \& Alfoldi, 2012). 


\section{Chapter 4: Report of Findings}

\section{Introduction}

As outlined in Chapter 3, this study was designed to examine the lived experiences of nontraditional community college students, in relation to their education and retention. Additionally, the study set out to identify themes and concepts informing the essence of being a nontraditional student in a community college setting. Data analysis was completed using the Stevick-Colaizzi-Keen method identified by Moustakas (1994).

The following sections in this chapter will discuss trustworthiness, significant statements and themes, and individual textural, structural, and textural-structural descriptions.

\section{Trustworthiness}

Lincoln and Guba (1985) state that trustworthiness can be simply defined as a way to get others to pay attention to the results of a study. Within a phenomenological study, epoché is used to help establish trustworthiness. Epoché requires the researcher to look upon the phenomenon naively, through a pure consciousness (Moustakas, 1994). For this study, the researcher attempted to clear the mind of any prior influences, in an attempt to see the phenomenon and to be "challenged to create new ideas, new feelings, new awareness and understandings" (Moustakas, 1994, p. 86). Although difficult to truly clear my mind of any prior influences, I was able to recognize my preconceived notions of nontraditional students and attempt to set those thoughts aside. Interviewing participants, reading verbatim interview recordings, writing post-interview field notes, and analyzing photographs are examples of the researchers mode of encountering the phenomenon without bias.

To increase trustworthiness, Lincoln and Guba (1985) argue that there are four key categories: credibility, transferability, dependability, and confirmability. Regarding credibility, 
Lincoln and Guba (1985) posit that prolonged engagement and triangulation are two key ways to increase the likelihood of establishing credible findings. Using Seidman's (2013) three interview series in this study assisted in the establishment of credible findings. Additionally, the researcher has worked in the community college field for over five years as both an administrator and faculty member. This experience has helped with the prolonged engagement with the population and has facilitated "learning the culture... and building trust" (Lincoln \& Guba, 1985, p. 301). Interviews, participant journals, and photographs will assist with triangulation.

Creating a rich, thick description through a paper trail of detailed outlines, transcripts, field notes, journals, and photographs will allow other researchers to replicate the steps followed for this study. This promotes transferability because "the description must specify everything that a reader may need to know in order to understand the findings" (Lincoln \& Guba, 1985, p. $125)$.

Dependability can be viewed as an "inquiry audit" (Lincoln \& Gubs, 1985, p. 317). An inquiry audit refers to an external individual that would examine the process of gathering information and to study the product from the point-of-view of their accuracy. Lincoln and Guba (1985) state that confirmability refers to the ability of another researcher to confirm the findings, eliminating the researcher's bias. For this study, a colleague, who is trained as a lawyer, read through the project to help ensure a proper inquiry audit. With the exception of certain terminology, the researcher's colleague did not have a difficult time following the steps taken during the study.

\section{Significant Statements, Themes, Textural and Structural Descriptors}

Transcripts of all interviews and journal entries were reviewed multiple times. Forty-five significant statements (see Appendix H), or horizontalization, were listed and is a part of the 
reduction process. If statements were repeated or did not pertain to this study they were eliminated. Through elimination what remained are considered the horizons of the experience.

Out of the significant statements emerged four themes. According to Moustakas (1994) "the clustered and labeled constituents are the core themes of the experience" (p. 121). The four themes are motivation, helpful/caring faculty and staff, external responsibility, and past educational experiences.

As previously described in Chapter 3, the "what" of the experience is considered the textural descriptions. The textural descriptions tell exactly what has been experienced in their lives and includes verbatim examples. In turn, a structural description for each participant details "how" the phenomenon of the participant's time in college and persisting toward graduation was experienced and includes factors leading to such a decision. Both the textural and structural descriptors were analyzed to produce a textural-structural description for each participant.

\section{Participant 1: Kathy}

\section{Biographical Information}

Kathy is a 35 year-old White female enrolled in an AS (Associates of Science) degree for Social and Behavioral Science and will be graduating in the spring of 2014. She is married and has three daughters who all live at home. Kathy has a part-time job working with a local movie rental shop and goes to college full-time. Of all participants in this study, she has the fewest nontraditional characteristics defined by Choy (2002). Kathy's two traits consist of being financially independent and having dependents.

\section{Textural Description of Kathy}


The first interview was an attempt to better understand the participants past educational experiences prior to college. Beginning with middle school, Kathy recalled negative social experiences as opposed to anything pertaining to actual schooling. She describes hating middle school, going as far to say, "I think this was the worse three years of my life." Asking why it was such a terrible time, she stated that during that age it distinguishes who you are and where you fall in the class of society.

Kathy's home life during middle and high school was not much better regarding her education. Her parents rarely took interest in her schoolwork, never asking if her work was completed or taking the time to sit down and help with her assignments, "so I either figured it out on my own or became friends with my teachers to learn it." However, Kathy was quick to defend her parent's lack of dedication to her work, "they didn't know what they were doing." Her dad never completed high school, but her mother did obtain her high school diploma and a certificate to be a nurse's aide. Her father worked during the day and mom worked at night, which made Kathy feel obligated to help her brothers with their school work, if she knew how do complete the task at hand.

Kathy became the first person in her family to attend college. Initially, she went straight into community college after high school, but quickly dropped out after one year due to family issues and a lack of academic discipline. However, she decided to return to college after a 16year hiatus. During that time she got married had three children and worked odd jobs. I asked why she decided to return to college and she elaborated upon the fact the movie store she works in may close and she is not sure what else to do, “it's been one remedial job after another, but if I want something substantial I will need at least my A.S.” 
The application process and returning back to college was easy for Kathy, "although it was the 90s when I was in college initially, nothing is too different." During her first semester back she registered for 12 credits, which was manageable for her and her lifestyle. However, during her current semester (fall 2013), she is registered for 16..."16 is too much. It is very hard for me to balance everything I have to do. You wouldn't think that one extra class would make a big difference, but it does."

Kathy elaborated a few times about her experiences with students of traditional college age. She is very adamant when talking about how during her first time through college that she messed up and did not take it seriously. She goes on to say that:

Now coming back and looking at some of these younger kids I'm in class with...I just want to beat their heads on the wall. Why are you wasting your money, your mom's money, or whoever's money and the professor's time, if you are not going to give it the effort it needs. I'm sure there are people here with a more chaotic life than mine, but if I can juggle it...you as a dorm student who have no real responsibilities should have no reason you are failing.

The college offers a variety of services to students, from counseling to a library to student life activities. However, Kathy only utilizes two services offered, the library and occasionally the tutor center. This is due to her busy schedule at home and work (which will be elaborated on the structural description). She does have a hybrid course (a combination of online and face-toface), which she likes but feels that a full online course is not conducive to her learning style. While talking about this course, Kathy again shares a story regarding a younger student and their motivation: 
The professor mentioned that a few students still had not done their online assignments and one boy said he didn't have time. I was like it takes one hour a week to do this...you can't find one hour in a week? It just made me so mad. He said he had baseball to worry about and I blurted back...I have 3 kids, a husband, and a job...so your baseball is not important.

Kathy refers to her time in college as "the hardest thing I have done in my life and I have given birth to three kids on no meds."

\section{Structural Description of Kathy}

As briefly mentioned above, Kathy's parents were not a big part of her schooling while growing up. Kathy indicated that it might have been due to their own lack of education that prohibited their involvement. With one parent gone either day or night due to work schedule, Kathy frequently helped her two brothers with schoolwork. However, she states that they were undisciplined and was not their mother so "I couldn't make them do their work." Both brothers to this day have not attended college.

When discussing her middle school experiences, Kathy's focused on her personal and social status. She did not fit into any cliques, was a loner because her family life was different; “we didn't do boy scouts or girl scouts or after school activities. So we just went home after school did our work and hung out. I didn't have a lot in common with everyone else."

The decision to go to college was never pushed upon her at home; "they never really said or pushed that I need to go to college to better myself. If I wanted to work at Burger King that was ok with them." Yet, Kathy admits that it is different with her own kids. She wants them to be the best they can be and strive for the best because "I know how it made me feel not having that kind of support... it always made me feel like they didn't have confidence in my abilities. 
Work and family were major reasons she returned to college. With the video store potentially closing, she knew she needed to further her education to obtain a better job to still provide some income for her family. Additionally, family and work commitment is a central part of Kathy's life; which always impacts her educational experience. Her family determines the amount of credits she can take in a semester; "had it been just me and my husband there would be not problems, but having 3 children under the age of 12, they have responsibilities of their own." She further states that "I can't tell my kids, no, I'm not going to read you a bedtime story because I have history homework.” Additionally, working two days a week directly impacts the amount of time she can commit to schoolwork.

Kathy does receive support from home to go to college. She is especially appreciative that her husband is supportive of this time away. Yet, she feels that she is being selfish because of the time away from her children and husband; "I have been homemaker for so long, I don't feel like I should have to take time for myself, but I know in the long-run it is to make it better for my family."

There is no real interaction with social events or clubs on campus for Kathy. The time to attend such events does not fit into her outside schedule. Interaction with students is rare, only the occasional life-lesson speech detailed in the textural description section above. However, Kathy does speak about a younger student who she has befriended. The student is from an urban environment (SCC is in a very rural, isolated community) and Kathy has helped her with some classes and provided some home cooked meals. Interaction with faculty has also been limited but she credits two faculty members with helping her figure out what degree to pursue.

\section{Textural-Structural Description of Kathy}


Before enrolling in college, Kathy was unsure where her life was going to take her. Being a spiritual individual, Kathy frequently attended church to pray about what steps she should take (Figure 2). With the added support of well-placed SCC advertisements at her job, Kathy's praying led her to enroll at SCC. Kathy "relies a lot on Godly answers" and what came from her spiritual reflections was the understanding that she could be better and that she "didn't have to accept where I was and that things can be changed." She states that she cannot sit idol for very long, but when she browsed the job options there was not much available unless she had obtain at least an AA.

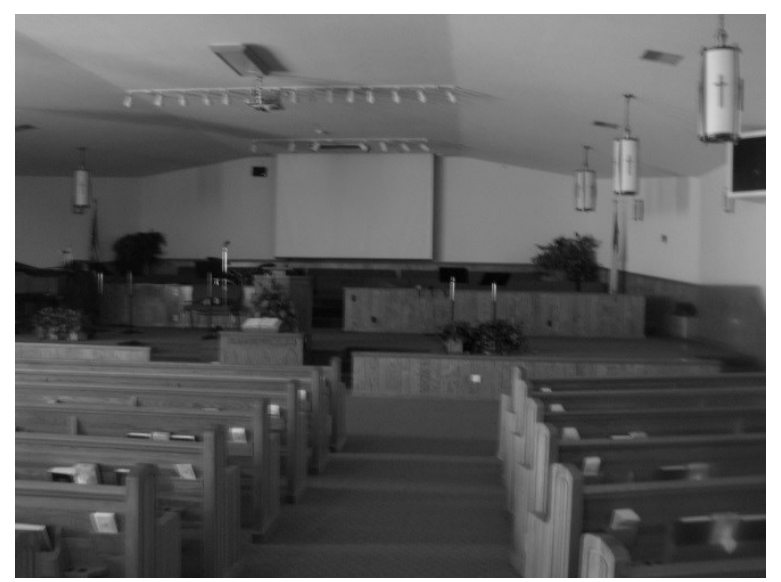

Figure 2. Spiritual Guidance

Kathy has had an up-and-down experience with education since middle school. Social isolation and the lack of family support made her early experiences tough. However, she credits her current family as the main engine to propel her to attend college and finish her degree. Kathy's husband (Figure 3) is a main reason she has persisted in college. He helps Kathy when she needs to focus on schoolwork, or to pick up the kids from school or attend PTO meetings, "he helps keep me grounded, helps pick up the slack. But he also encourages me on those days that I just want to give up and quit school." 


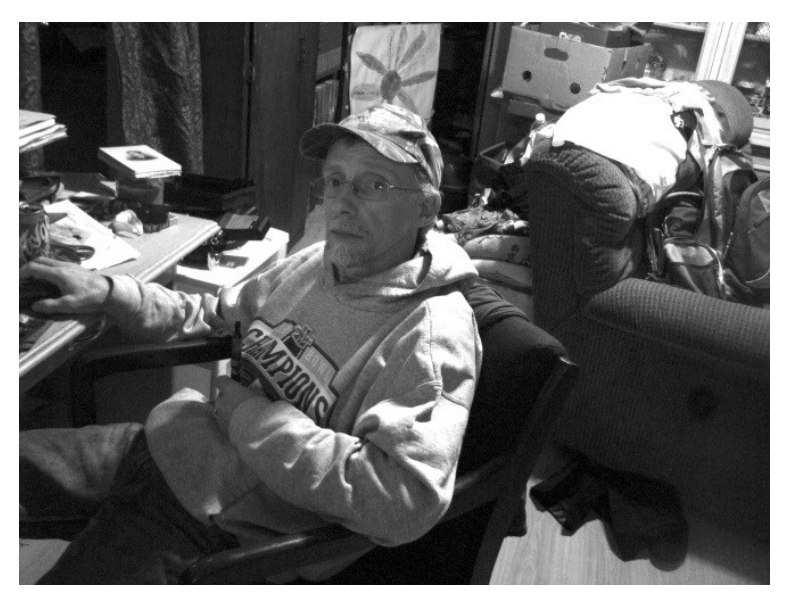

Figure 3. Family Support

"My mom is going back to college" is one of the first quotes Kathy uses when talking about her children. She is very excited to talk about the fact that her children brag to their friends that their mother is going back to college (Figure 4). Her children "make her want to be a better person" and she wants them to know that they can accomplish anything and have a better life than she did growing up. However, Kathy feels "guilty" sometimes attending college because "I'm giving up my time with them." She sees her attendance in college as having to put her children "on hold." However, she goes on to reflect that, "in the course of doing this project with you, I guess I shouldn't feel selfish, it is ok to take time for myself."

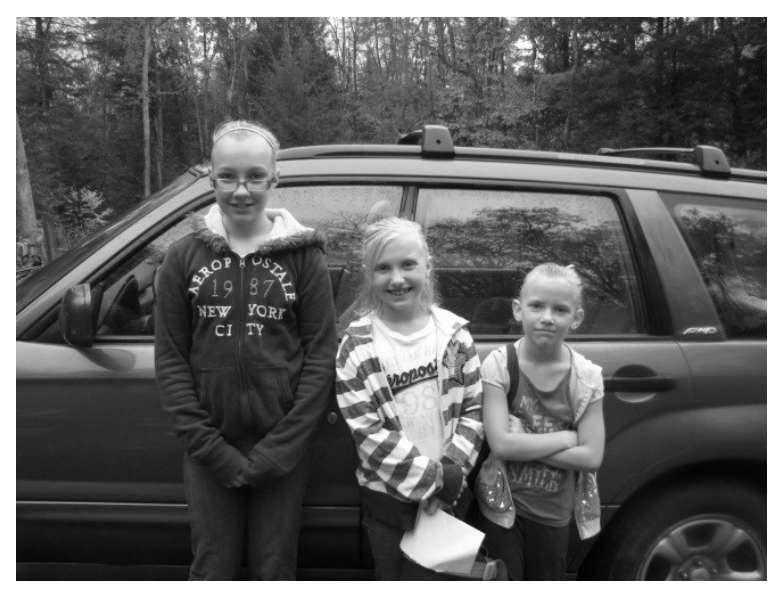

Figure 4. Inspiration 
Like many nontraditional students, Kathy has to balance a job as well as schoolwork and family commitments (Figure 5). She took the picture of work to represent future opportunities, because "with the business potentially closing in the future, I wouldn't of thought of going back to school." Yet, even though the business may not close, Kathy realizes that her current job may not always support her family financially and in order to get a better job she will need to further her education. She elaborates on her current position, "there is no higher up where I am in this job, other than owning it. I would be a cashier my whole life...there is nothing wrong with that, but you have to have dreams or goals for yourself."

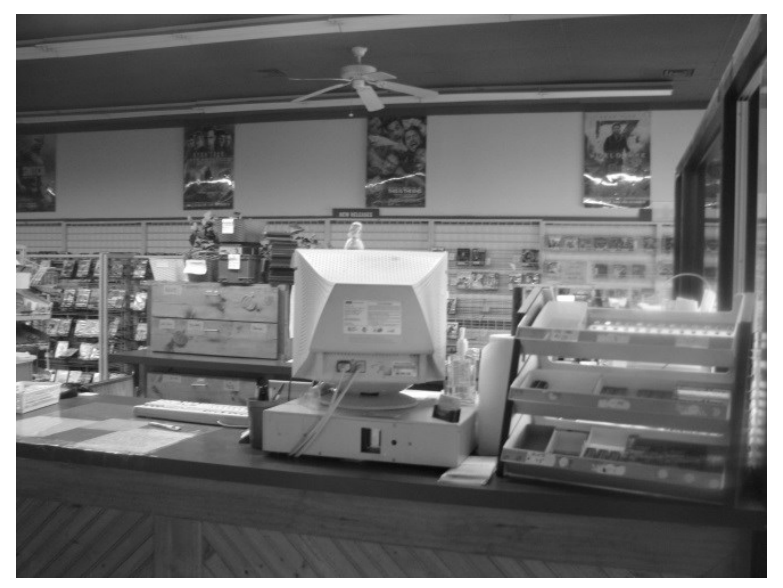

Figure 5. Kathy's Work

"It's going to be huge! I can't wait to be in that picture!" Graduating from college is a point of excitement for Kathy (Figure 6). When talking about this picture, Kathy becomes very emotional and tears up. She states that "self-esteem wise, to prove to myself, even if no one else did, that I did it. No matter what the world throws at me, I'm here and I have my degree." Having seen this task through until the end is a major accomplishment for Kathy, and it is this drive and determination that has helped propel her to finish. 


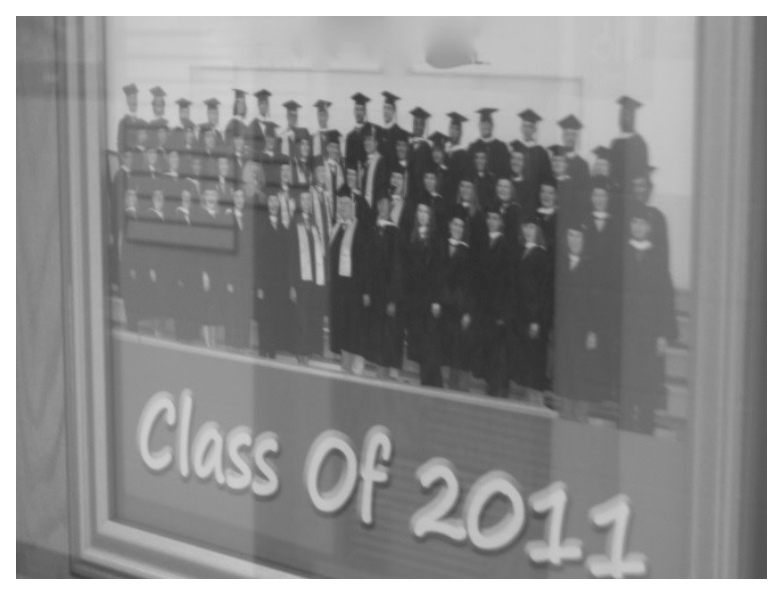

Figure 6. Sense of Accomplishment

Figure 7 sums up Kathy's experience in college: change. Being the first person in her family to attend college and persist until graduation makes her very nervous. She senses a lot of pressure but it will be a very proud moment for her: "it doesn't matter where you are in life, you don't have to settle." It is at this point that Kathy once again compares her experiences to those of traditional age: "I have not had to pay anything out of pocket for my education, I see this as a blessing from grants and loans and I see that younger people come in and think it is free money." She further stresses that typical students do not have an outside job, children or a spouse to worry about, "their responsibility is to come to school and do their best... why waste this opportunity?"

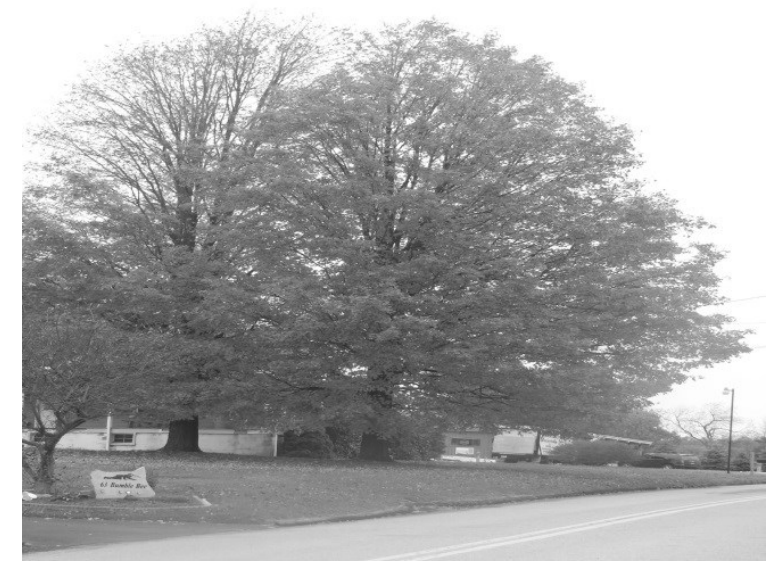

Figure 7. Change 
Kathy views education as important in life. In her own words, she is not a "quitter" and this is why she has stayed in college, "I have quit things before but I don't want to be labeled a loser. I have tried diets and gym regiments and they all fizzled out. I want to stick to this to the end because it will make me better."

\section{Participant 2: Jennifer}

\section{Biographical Information}

Jennifer is a 49 year old mother of two and recent divorcee. She is obtaining her degree in General Studies and hopes to transfer to a four-year school upon graduation. Jennifer works full-time with a local arts and entertainment organization located on the campus of SCC, which makes her educational attainment more manageable. Under Choy's (2002) definition of nontraditional, Jennifer would be considered highly nontraditional. Her traits include financially independent, has dependents, delayed enrollment, and attends part-time.

\section{Textural Description of Jennifer}

Growing up in the same town, in which SCC is located, Jennifer remains friends with some her classmates going as far back at $1^{\text {st }}$ grade. She has many fond memories of her early education. Jennifer's experiences with good teachers made her early education an enjoyable process, "my $3^{\text {rd }}$ grade teacher is someone I wanted to emulate." She elaborates on another teacher later on who was "dynamic and attractive" as opposed to another teacher who was "meek." Jennifer had to work hard to pay attention to her mild teacher, whereas the "energetic" teacher kept her on her toes. Having good teachers was a common theme for Jennifer, moving into high school her $10^{\text {th }}$ grade math teacher could "walk on water" for his ability to get her to like geometry. 
It seems that her experiences were heightened due to the fact that her parents were close friends to many of her teachers and her dad was on the board of education in the community, "due to this relationship, I think I always wanted to please the teacher. The teacher was always right and if I got in trouble at school I would get in more trouble at home."

Jennifer met her future husband while she was a junior in high school and he was a freshman at a four-year university. Two weeks out of high school she got married. Yet, she had full intentions of going to college; she loved education, "in my wedding announcement my plan was to attend college." Both parents were college graduates, so it "was the next step in my life." Jennifer recalls sitting her house deciding which college to apply for but her future husband said, "no, if you go to college that will be the end of our relationship." She senses that this was a jealousy issue, "he had gone to college and knew what it was like," but she still wanted to attend college. It wouldn't be another 20 years before Jennifer would go back to college with the intent to graduate.

After decades of odd jobs, a divorce, and a few professional development courses, Jennifer was persuaded by a friend and SCC employee to consider coming back to college. Her friend informed her about programs that took life experience into account when considering credits toward a degree. That was a relief for Jennifer who would have had to start from the beginning if the program did not take life experience into account.

Jennifer initially took some online courses through another four-year university, but it proved to be too daunting. The combination of no face-to-face interaction and regularly dealing with teaching assistants, as opposed to full-time professors, resulted in Jennifer leaving that program. The decision moved her to SCC, which is local for her and also the location of her current job, "with my job on campus, I would be stupid not to take advantage of this situation." 
Coming back to a brick-and-mortar college, Jennifer wasn't looking for socialization, just the degree. She views herself as an outsider among the traditional students, "why is this old woman in our class... what is she doing here...this is our college experience." Although a primary concept of community colleges is for individuals at any stage of their life to come back to school, Jennifer still views herself as "invisible" and a time for others to "find out who they are and what things you like and dislike. I'm not looking for that experience, I am who I am now."

Jennifer's son attended SCC with her until he graduated and moved onto a four-year institution. She credits her son's success, and her own, to dedicated faculty at the college: There is something extraordinary about the faculty here. Knowing that there are people out there to reach out and encourage me is crucial...they don't have to do that...they will get their paycheck no matter what and that is an employee you want to keep.

\section{Structural Description of Jennifer}

A focal point of the Jennifer's structural experience with education is her relationship with her ex-husband. When he initially told her that he did not want her to attend college it was a "mixed bag" of emotions, "I was in love with him, but I still wanted to go to college." When she would press the topic to him early in their marriage, he would cite the high cost of education and that he would not pay for her schooling. Her husband would remind her that they live in a small community and will never leave, so why does she need a college degree, "someone had to give in and I did." This decision to "give in" resulted in years of random jobs and an eventual return to college 20 years later. 
Since returning to college, Jennifer's home life, like most nontraditional students, has played a significant role in her educational experience. The opportunity to attend college with her son was a wonderful experience, but at the same time, "things happen with your kids" that take her away from her school work. For example, Jennifer tells me about the other day while she was doing schoolwork and she received a call from her daughter's school, informing her that she was bullied at school. Jennifer, of course, drove to pick up her daughter to be sure all was well, "Being a parent comes first," stated Jennifer, "school work can wait on days like this."

Working full-time presents additional challenges upon Jennifer. Finding classes that are conducive to her schedule has proved difficult, "finding classes later in the day in crucial for me and work, like even now, I'm not sure what I'm going to do next semester to fit all my classes in.”

\section{Textural-Structural Description of Jennifer}

Jennifer's educational experience has been focused on one goal: "to get done!" Completion is her main concern and if the traditional college experience (i.e., socialization) happens than that is great and she would appreciate that opportunity. However, Jennifer is not looking "for life-long relationships," she is here to graduate and move on, "getting my college degree has always been a bucket list for my life."

A common theme throughout Jennifer's interviews was her positive experiences with faculty and staff. The positive influence and additional help faculty and staff provided her and her son, during his time at SCC, has made Jennifer's college experience as wonderful as her time as a middle and high school student.

The first picture Jennifer took was of a faculty member at SCC (Figure 8). Although the professor helped her during her time at college, Jennifer took this picture for the help he 
provided to her son. Jennifer indicates that her son struggled throughout college until he landed within the wildlife program. She states, "He was instrumental in helping my son find his passion and help him get on with his education." This, in turn, had a positive impact on Jennifer, because, "if your son finds his way, it gives the two of us something to talk about. I really admire him and appreciate all he has done." Jennifer views her status as a nontraditional student as someone who can appreciate meeting those instructors who go above and beyond to help a student, "you understand that extra effort that traditional students more than likely do not appreciate."

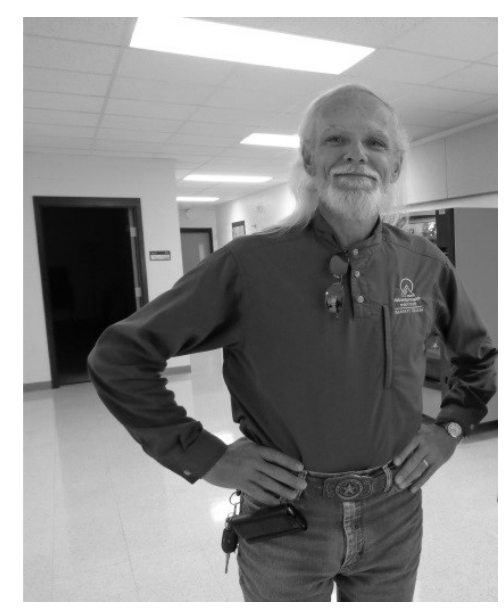

Figure 8. Helpful Faculty

Continuing with the theme of supportive faculty and staff, Jennifer views Stacy (Figure 9) as the catalyst that moved Jennifer to enroll, "I wouldn't be here today if it weren't for Stacy." Stacy had gone through the same regents program that Jennifer is pursuing, so she was able to provide plenty of information for Jennifer to consider. Jennifer feels fortunate to have had this meeting with Stacy, because when she first contacted SCC, they were unaware of the regents program and informed her that even though she had worked for the past 20 years, she would have to start from scratch to finish her degree. 


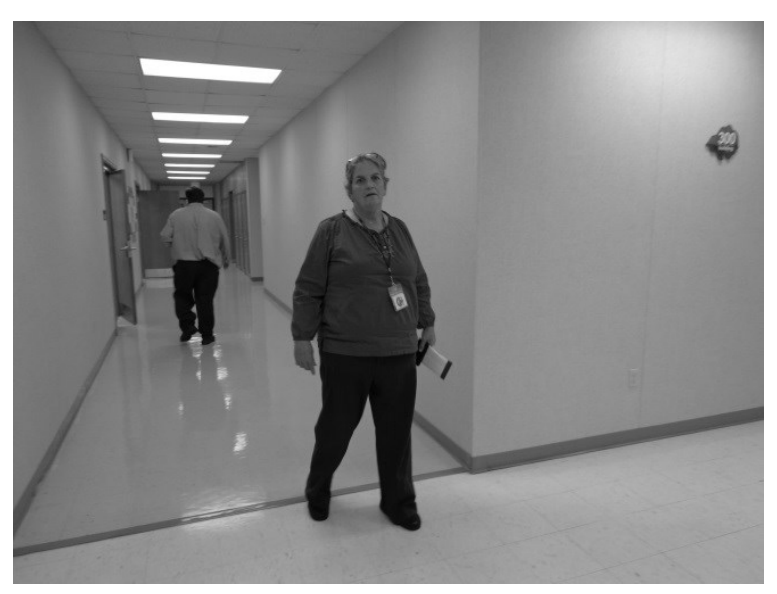

Figure 9. Encouraging Staff

Having her place of employment (Figure 10) located on SCC campus (although not part of SCC) has been very beneficial for Jennifer and her academics. The time that she can continue to dedicate to work as well as school has made her efforts toward degree completion an easier process, for example, "like last night I worked until 5:30, then went over and took my night class and afterwards came back to work and finished some approaching projects." However, Jennifer occasionally struggles with finding courses that are conducive to her work schedule, "I cannot take day classes, it just wouldn't work with my schedule." This balance is one of the more difficult tasks for Jennifer and the ability to have proper time management for all responsibilities.

The topic of responsibility turns Jennifer's attention to her perception of traditional students, "they have missed opportunities and I really regret not taking full advantage of the opportunities that were give to me. Last night in my communications class, I gave a speech about opportunity and how younger students should learn from my mistakes." 


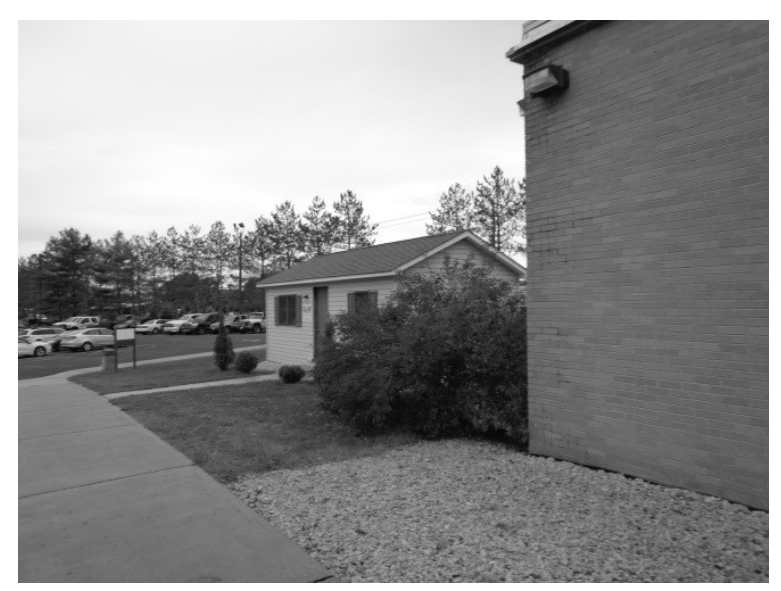

Figure 10. Work/School Balance

Jennifer's children have been very supportive of her returning to college. As mentioned previously, her son attended SCC with her until his graduation, which was a wonderful experience for Jennifer. Figure 11 is a picture of her daughter, which Jennifer indicates is a representation of balance. Just as with her work life, there are time management struggles to balance with her family, Jennifer states that "school keeps me from doing everything that I would like to do with my daughter. For example, my daughter wanted to take singing classes, but she could not do it because it was during the same time as one of my classes."

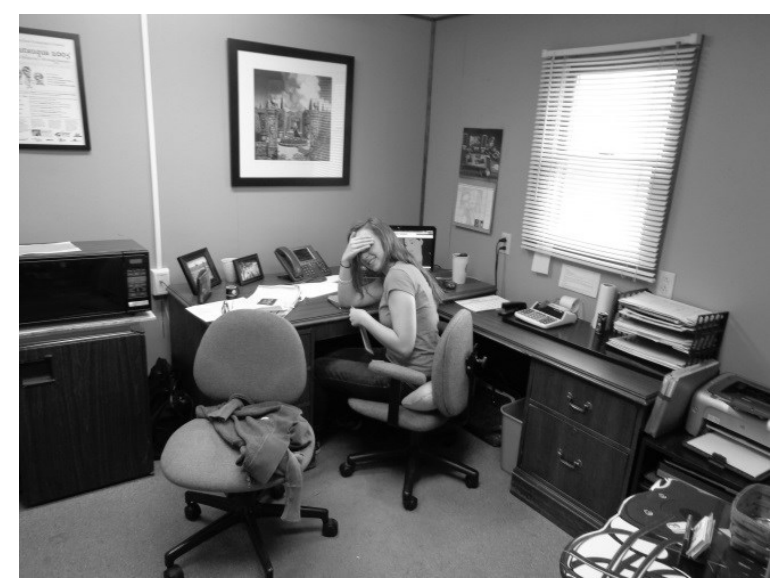

Figure 11. Balance of Family 
As mentioned in the textural and structural description sections, Jennifer had a difficult time returning to college, due to the influence of her ex-husband, "there is a little bit of embarrassment because I didn't stick to my guns and go back to college earlier. Yet, it is the sense of accomplishment and desire to have the ability to say, "yes, I graduated from college. I have waited practically 20 years to get to this point...I want completion.” Jennifer wants that sense of accomplishment, but also needs to further her degree for financial stability. With her divorce recently finalized, she will need to better herself through education to sustain her livelihood, obtain health benefits, and the ability to save money for retirement.

Education is "important, valuable, required, and essential” part of Jennifer's life. A degree is a need not a want, unlike most traditional students, according to Jennifer. The hope for a better future for herself and her family is a major driving force behind Jennifer's desire to persist until graduation. Jennifer's experience can be summed up with the picture of Stacy in Figure 9, because "she reached out to me and its not her job to do that... why does it matter to her, that is just extraordinary to me."

\section{Participant 3: Douglas}

\section{Biographical Information}

Douglas is a 47 year-old married father of four children. He has a full-time job working with a local research and design company, specializing in miner safety, oil and gas, and construction. Douglas is finishing up his degree at SCC in electrical engineering and hopes to attend a local four-year university upon graduation. He is one of the three participants that have four of Choy's (2002) nontraditional characteristics: financially independent, has dependents, delayed enrollment, and attends part-time. 


\section{Textural Description of Douglas}

Douglas has grown up his entire life in the community surrounding SCC. Growing up on a farm with parents who valued hard, physical labor more so than schoolwork, made the thoughts of college difficult. His father never had an education past $8^{\text {th }}$ grade, but his mother did graduate high school, "they were pretty successful with the dairy farm, so I guess the importance of school was not a top priority for them.”

However, Douglas had a passion for "how things worked." He enjoyed taking things apart, from toys to farming equipment, "my mother used to tell me she wasn't sure why they bought me Christmas presents, because I would just end up taking them apart." With his talents, he was able to join a gifted program during middle school, being able to study topics such as Three Mile Island and nuclear power, but "by the time I got home, I would do as much homework as I could before having to go and work on the farm. I didn't always do as much homework as I should or could have."

In high school, Douglas did better academically, especially in math. However, English always proved to be a difficult subject for him, "I struggle with it do this day. I guess because it isn't a science." During the 1980s, Douglas attending high school when students could pursue two different tracks: college prep or vocational. Even with his upbringing, Douglas chose the college prep route, "this was a time when computers were starting to be introduced and that really interested me." However, due to his limited capacity in English, he had to drop that portion of college prep and took English based in the vocational training.

Nearing graduation from high school, Douglas wanted to pursue a college education in engineering. Although his dad was not outwardly opposed to his son attending college, Douglas' father asked that he work on the farm for a year and then they could revisit the idea of college, 
“college just ended up not happening. Life happened." He ended up getting a construction job and had the opportunity to utilize his engineering skills somewhat, working on drafting.

Douglas took some professional development courses during his almost 26 year hiatus from college. During this time he got married, bought a working farm and had his children. Nowadays, with his children getting older and going to college themselves, Douglas decided to pursue his college degree, "my kids are not interested in working on the farm and I'm not going to push them one way or another." The opportunity to finally go back to school is one of excitement for Douglas. The chance to share ideas and experience the knowledge of individuals across multiple disciplines is something that he enjoyed the most so far in his educational experience.

\section{Structural Description of Douglas}

"Finding time," that is the hardest part of coming back to school, according to Douglas. The time it takes to leave work, drive to the college, drive back to work is a difficult task to balance, "I lose an hour of travel time to-and-from work." This balance has been a stressful part of his experience, "they have their own cycle (work, school, family) and every once in awhile they all hit at the same time."

Douglas' employer had no concerns with him returning to school part-time, as it would benefit them having an electrical engineer on staff. With his children not taking ownership of the farm, something he would like to work on as a hobby, Douglas felt he was at a transitional time in his life and wanted to pursue education.

Interaction with other students is virtually non-existent during Douglas' time in college, “I'm here and back out again. I don't have time to hang out or even do a study group." Douglas 
typically will bring schoolwork to his job to work on afterwards due to the hassle of traveling back-and-forth.

A factor for Douglas to attend college was to be closer to his family. He entered SCC during his daughter's final semester at the college and currently is enrolled in similar classes with this son. His daughter was excited to see her dad on campus and pursuing his educational dream and his son's personality is one of indifference, but "that is just my son." Douglas laments on the fact that he is taking a chemistry class that his son had to drop, "I would have liked to help more but with all my other work, I just didn't have the time." However, his wife struggles from time-to-time with the clear benefit of his college experience, especially since Douglas is not doing this for a better job.

\section{Textual-Structural Description of Douglas}

The first five pictures Douglas took involved his job; this really emphasized the importance of this job and its role his educational experience. Figures 12 and 13 are brief samples of his job and the technical skills they require. He does not need the AA degree to keep his job; he enjoys his current employer, but would like to advance within the organization. Stemming back to his childhood passion of "taking things a part," Douglas feels this job helps fulfill that inner desire to better understand "how things work." 


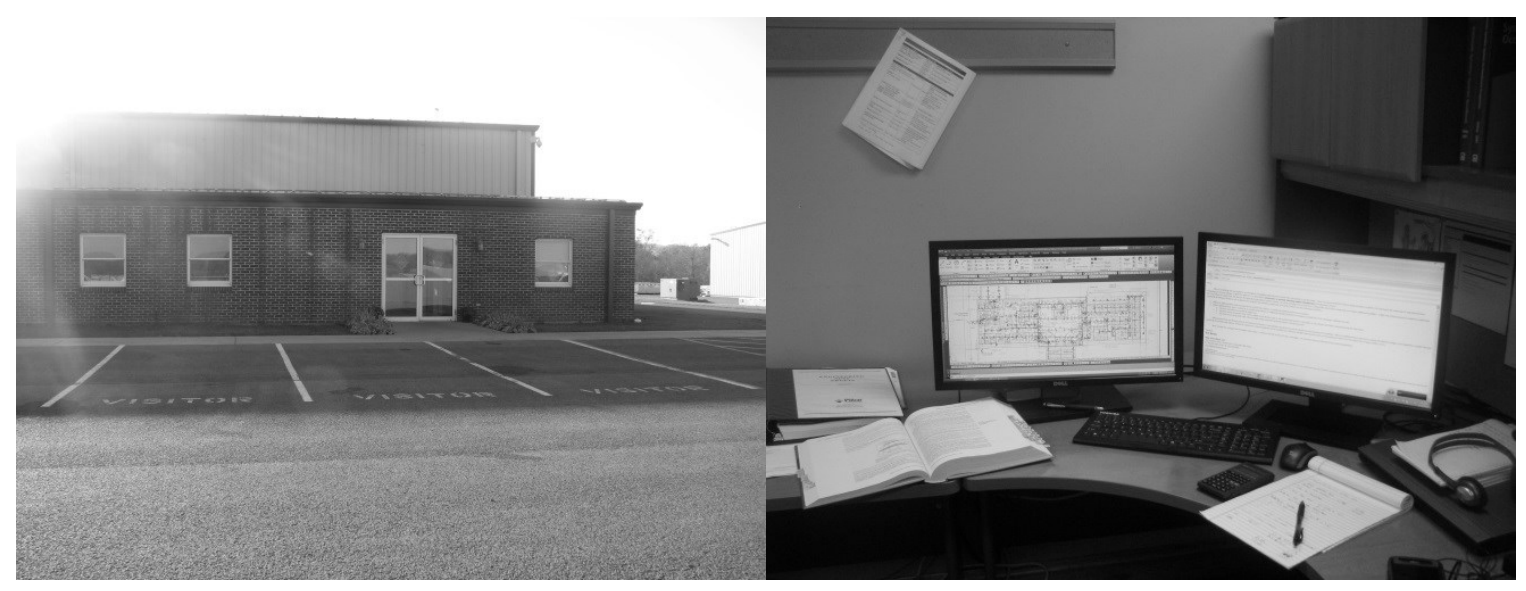

Figure 13. Passion of Work

Figure 12. Hard at Work

Figure 14 represents location and opportunity for Douglas. Had SCC not recently offered the electrical engineering program, he would have not pursued this degree. Upon graduation, the four-year university he would like to obtain his bachelor's degree is in a practical driving distance (45 minute commute). Douglas, by his own account, would have never pursued his electrical engineering degree had, SCC not started offering it, "I would have stayed at my job, and although the thought of the degree was always in my mind, I would have never pursued it any further."

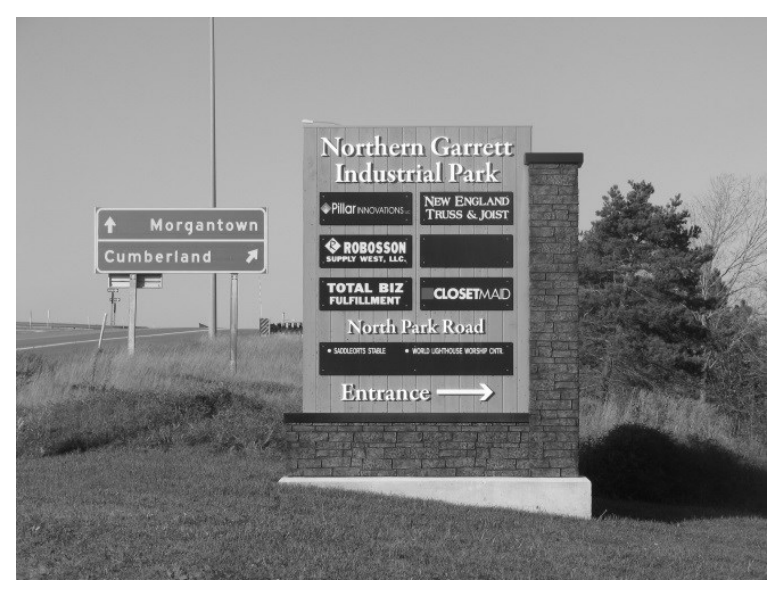

Figure 14. Opportunity 
Douglas has grown up around the SCC area his whole life, being raised on a farm and eventually buying a farm for him and his family. His farm (Figure 15) represents his love of physical activity, the continued passion of understanding of how things work, and his foresight into the future of his family. With this children moving away or going to college, he does not see any of them taking over the farm and "I won't be able to do it forever." So, Douglas has taken stock in his options and has pursued his degree to plan for potential future events, "it is a security blanket," Douglas says. He goes on to state, "what if I'm not physically able to do the farm and my current job doesn't pan out...the education is more transferable." "Sometimes I feel envious of students..." is the comment Douglas gives when talking about all the additional responsibilities his has on top of his schooling.

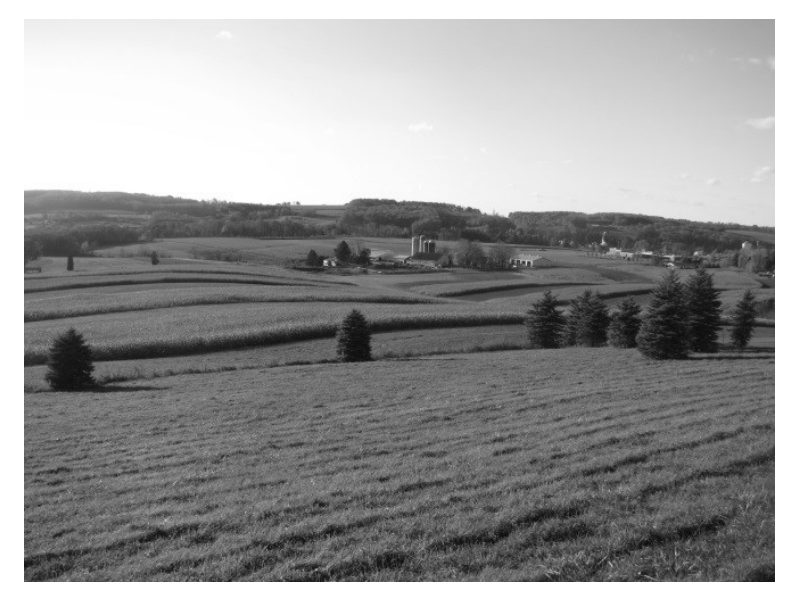

Figure 15. The Future?

Douglas' daughter captures his family experience during his time in college (Figure 16). Each of his children has been homeschooled, which kept his family close. Mentioned previously, one factor for returning to college was to stay close to his children, who also attended SCC. 


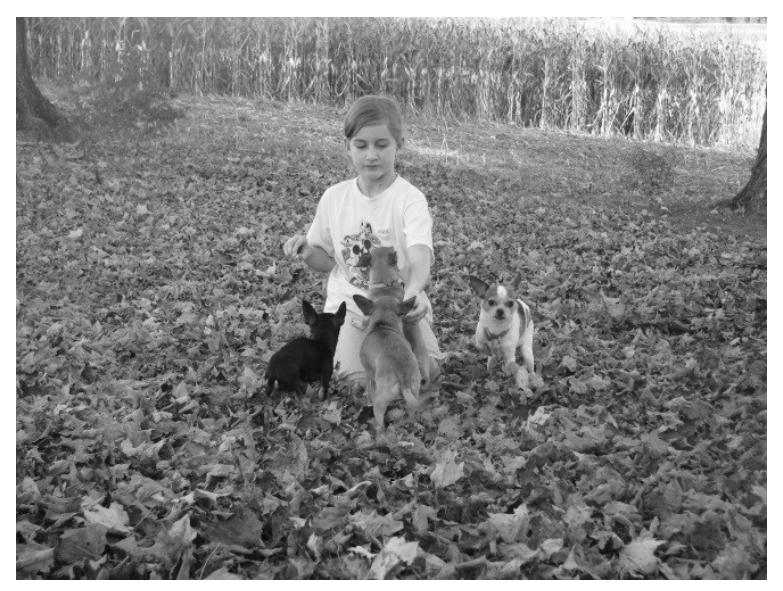

Figure 16. Balancing Act

Douglas is glad he has taken the opportunity now to attend college, "I don't regret anything leading up to this point, I'm just happy it is happening." His dad had Douglas stay on the farm after high school at least a year because he wanted him to learn responsibility, "nothing teaches responsibility more than having to work on a farm." As previously mentioned, life happened for Douglas and college fell to the side, but he is glad, that he is on his educational path now.

Douglas sees education as a way to open doors to opportunity. The electrical engineering degree drew him back into the educational process and realizes how important an education is in life, and "thinking back I wish I would have pursued it earlier." It has taken initiative on Douglas' part to "walk through those doors," and to take on additional responsibilities in his busy life.

The accessibility of SCC is a prominent factor that has kept Douglas in college, "if I couldn't balance work and family, I would not be here." The opportunity was presented and his job could of shut his educational pursuit down, his family had to be ok with the task... The initial meeting with his advisor, Shannon (Figure 17), was the final step in coming back. 


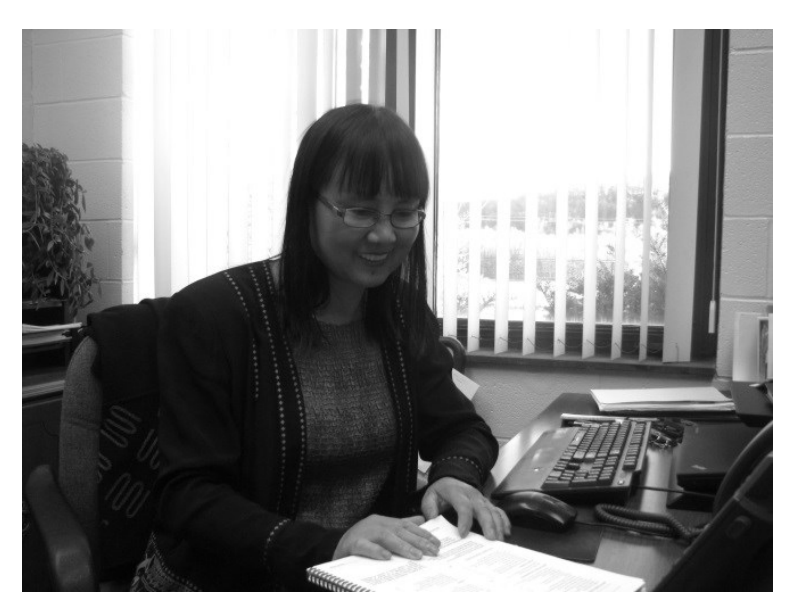

Figure 17. Help With the Final Step

\section{Participant 4: Debra}

\section{Biographical Information}

Debra is a 49 year-old widow with four children. She graduated in the December of 2013 (she was in her last semester during her interviews) with an AA in Juvenile Justice. Three of her children live at home; two in high school and one that attends SCC with her, with her oldest daughter living in Colorado. Debra does not plan on using her degree to enter any law enforcement agency, "it was just something I picked." She is a certified massage therapist and plans on working in a doctor's office upon graduation, "I need an AA degree to obtain a office job, it's that plain and simple." Debra's nontraditional traits, according to Choy, (2002) consist of financially independent, has dependents, and delayed enrollment.

\section{Textural Description of Debra}

Education was a struggle for Debra most of her life, complications with learning followed her during her entire k-12 experience, with math being a subject of much contention. She regularly skipped math and was able to coax her mom into helping her find excuses to miss class. "My mom enabled the situation," recalls Debra and used the made-up term "chief clubitis" as the mother-daughter code word to get out of school; she would fake a headache and be taken to the 
doctor's office. As far back as Debra can recall she would have rather taken a pill at the doctors than do math. She further explains that with all of the class time she missed due to "chief clubitis," that she was still pushed through math courses to be able to graduate.

She does not believe her schooling prepared her for college. Going to middle and high school in the 1970s, she saw her time growing up as an era when girls were not expected to go to college. This mentality was not a problem for the sociable, Debra, "I could of cared less, I wanted to be a beautician; I'm a people person. High school wasn't for me, I just wanted a vocation." However, becoming a beautician still was not acceptable for Debra's father, "my dad said don't worry about school, just marry a doctor, you'll be alright."

Debra met her husband (a dentist) after high school and although he sent her to some community college classes to help her read better and learn to type, he had the same mentality as Debra's father: be a stay-at-home mom. She did the billing for her husband's office until they had their third child, when she stopped working to put all efforts into their home.

When her husband died in 2000, Debra was able to get financial assistance to send her children to daycare. However, a requirement to send them through this program was for the agency to periodically check on the parent to inquire about their goals in life. Debra had no idea at that point, so she took what was called a Master Student class at SCC, which helped decide what interest they may have she decided to return to college. Debra tells me the story of why she really came back to college:

I had a boyfriend who was terrible to me..I was miserable. One day my daughter was leaving the house and she looked really happy. I said where are you going? She said I'm going to school. I thought to myself...if she can go to school and be 
happy, then I too can go to school and be happy. So if people are in a rut, I tell them to look at me and encourage them to go back to school.

When Debra returned to college she fell into the category of many nontraditional students: needing developmental courses and having an absence of study habits. Certain courses such as biology and psychology were a struggle due to her lack of knowledge regarding study skills.

Debra's experiences with classes have been one of passivity, with the exception of her art courses. Although not an art major, she is very happy to discuss her oil painting and ceramics classes, "I think the college experience has been positive and has helped me understand who I am and prioritize, which is something I try to tell others who are in my situation or used to be in my situation."

\section{Structural Description of Debra}

"I have a lot more responsibility than anyone else I can think of...," is one of the first comments made by Debra in our second interview. The responsibility of her children at home and three grandchildren has made her college experience more stressful than she anticipated. The opportunity to find a quiet moment at home to study is a rare occasion for Debra. In turn, she studies early in the morning, 5:00 am, or late at night, 10:00 pm, she continues, "the stress of having to stop everything to get your kid to football practice is not something most traditional students have to deal with." Debra has constructed a study area in her home, but it is located in the living room, "so when I come to school and I'm stressed out because I'm not prepared for class, it really gets to me sometimes. I just feel like I can never catch up some days.”

She believes her grades would be better if she could isolate herself for 3 days a week, but “in my stage in life, it's not really an option." However, Debra does take her opportunities to 
study when she can, occasionally locking herself in her car to find a quiet place to study, "what can I say? College takes a lot of dedication," smiles, Debra.

Mentioned earlier, Debra is a certified massage therapist. Although she enjoys her job, she knows it is not economically viable to continue in the profession, "I don't want to work for $\$ 10$ an hour anymore." She receives an income from social security until her son turns 18 , which she will lose in two years. Debra has the foresight to understand that she needs to be prepared to get establish a career, “I don't want a minimum wage job and I don't want to ask people if they want a shake with their fries for the rest of my life."

Debra's 20-year-old son, Ethan, attends SCC with her, but this experience has not been too positive. Ethan lives at home, has no job, and no car; with their neighbors frequently helping Debra getting Ethan to and from the college on days that she either is doing massages or taking one of her other children to another venue. "I am pissed," is Debra's comment about this situation with her son.

Faculty members that are encouraging and that set boundaries are individuals that Debra discusses the most throughout the interviews. Moreover, Debra's interaction with students is very limited. She always sits in the front of classes, explaining that, "I see the students as insignificant. Other students have no impact on my grade...its is between me and the teacher and the work I produce."

\section{Textural-Structural Description of Debra}

The responsibility of family and its influence on her educational experience is evident in Debra's first picture: Walmart (Figure 18). The job of a parent and grandparent to provide breakfast, lunch, and dinner requires her to travel to her local Walmart four-five times a week. Debra occasionally sighs at this picture, indicating that it is "just one more responsibility." 
Another picture Debra took was of a local laundry mat (not pictured). Although she does not use this facility, she took the picture to represent how she finds time to study, "often I will run laundry while I read my lessons and I try to use the weekend to catch up on my house."

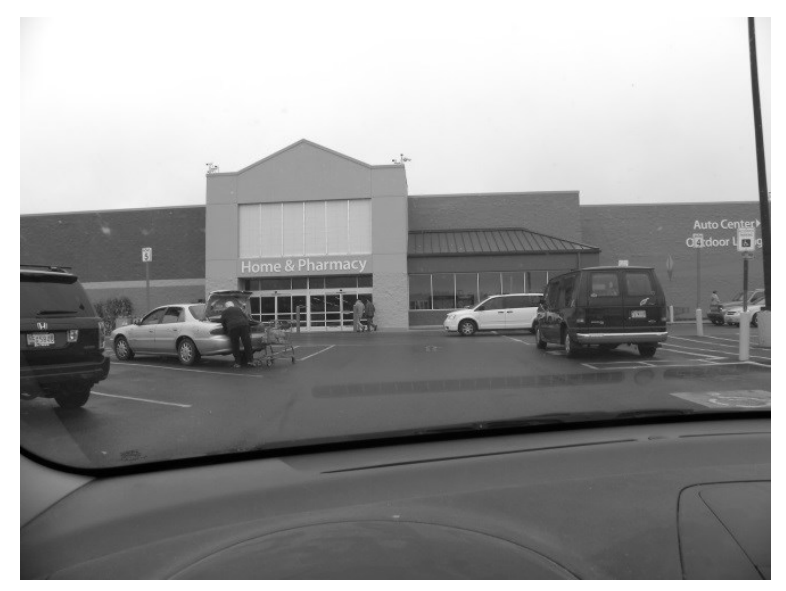

Figure 18. One More Responsibility

The passing of her husband in 2000 was an unfortunate catalyst that moved Debra in to college. She took a picture of her home (Figure 19) to represent the life she had with her husband, but also to show she is in a good place in her life with her children.

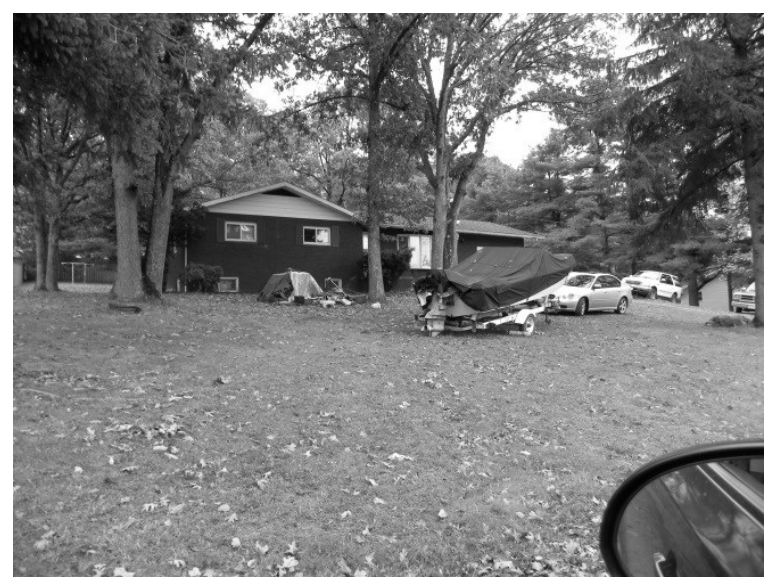

Figure 19. Home Brings Stability

Commuting to college is a common theme for many nontraditional students. When Debra first returned to college she was spending eighty-five dollars a week on gas with her old 
car, and she only lived approximately thirteen miles away from SCC. This total was due to her traveling to college, different massage jobs, and taking her kids to-and-from school. She was able to get a more gas efficient car recently (Figure 20), which has helped financially.

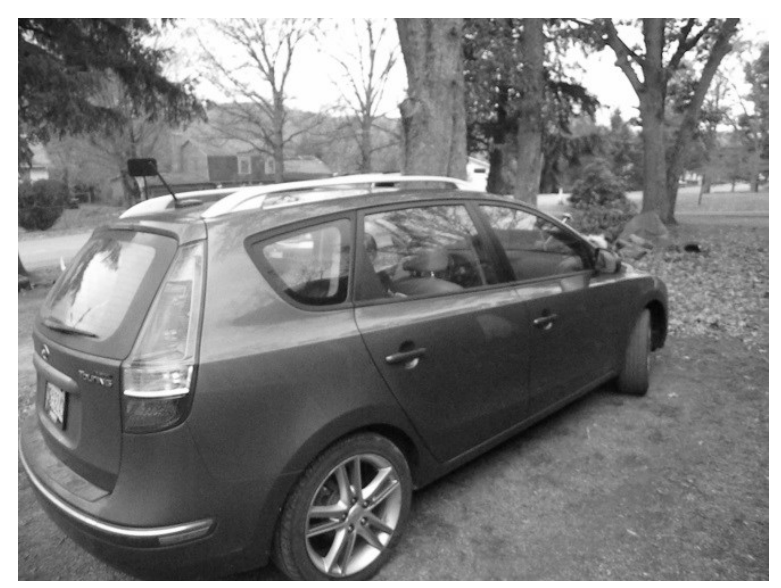

Figure 20. Travel Efficiency

With Debra's busy life, she has had to create a study area in the middle of her living room (Figure 21). Debra explains, "until my son is picked up or dropped off for football practice, dinner is prepared, and my two other children are taken where they need to go (they don't drive), only then can I sit down and study, but that is not until 10 or 12 at night." She further stresses on being the sole mode of transportation, indicating that her kids do not like their bus driver and refuse to ride the bus, which makes Debra their ride to school. She believes her children "feel privileged" and think "well mom will be leaving soon, so we'll just ride with her." Debra resents her children's lack of respect, "when I was their age, I drove and had my own car." She also would like for her son to have more responsibility and move out, "it just isn't fair some days."

Her schedule does not allow her to stay on campus and utilize student services, such as the library. Figure 21 is another representation of this full schedule, "I don't have time to be at 
the college any more than I need to be. I am at the mercy of my kids and all those responsibilities."

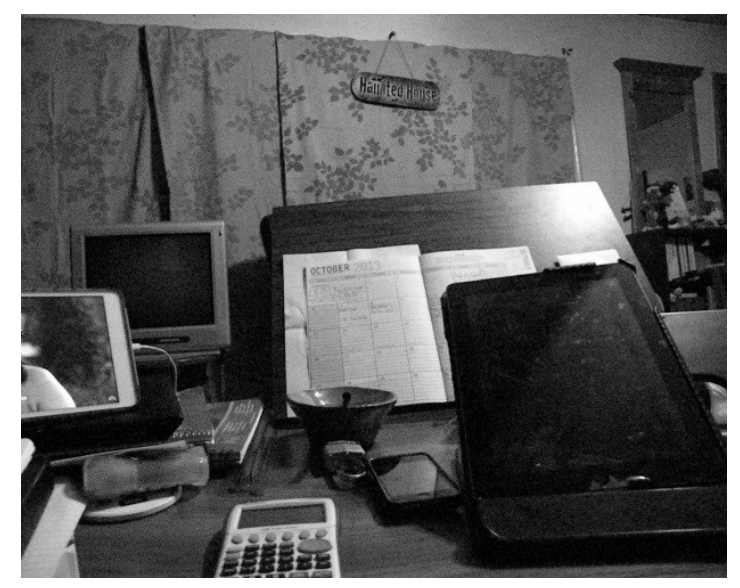

Figure 21. Solitude?

Mentioned previously, Debra did not talk much about student services. However, she did talk in great length about her love for her art classes (Figure 22). For three semesters, she has enjoyed the professor's art courses, “the art classes make me want to continue signing up for classes at SCC." Moreover, Debra views the art building as the one picture that has captured her educational experience; explaining that it was those classes that helped her become dedicated, "those classes made the whole experience worthwhile." Although these are her favorite classes, Debra does admit she is trying to have a better attitude with all academics. 


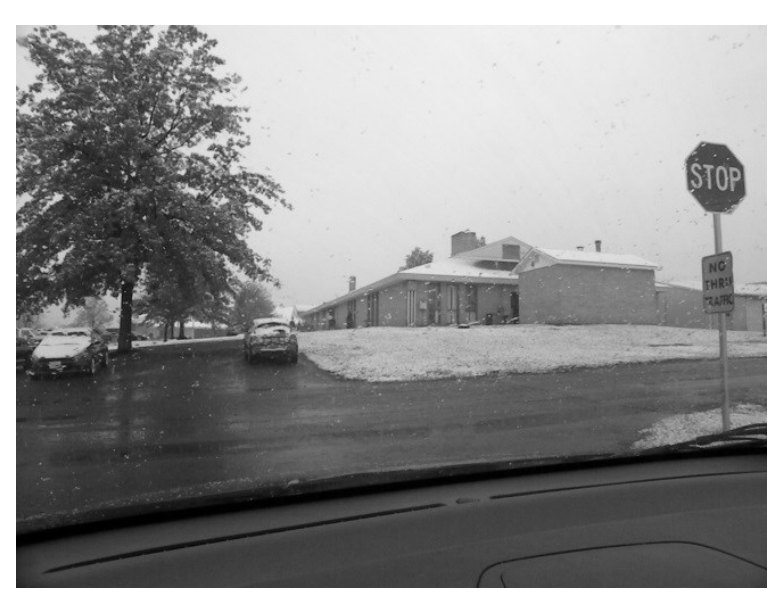

Figure 22. The Only Enjoyable Part?

Debra sees education as a vital part of someone's life. When she meets individuals that are in the same situation she was in, she actively encourages them to go to school, "if their road is a dead end or when they change jobs, I try to encourage them to try school." She views education as the opportunity to give individuals the light to find out who they are what they like. When discussing the factors that have prompted her to stay to graduate, Debra's simple response was, "I have always completed things I start."

\section{Participant 5: Jake}

\section{Biographical Information}

Jake is the youngest participant in this study at 28 years old. He is ex-military and lifelong resident of the SCC (excluding time away for military duty). His father is a retired military officer and both parents never obtained a degree past high school. Jake will be the first person in his family to graduate college; pursuing a degree in Liberal Arts. Upon graduation he would like to work for a federal agency, but "I'll see where the wind takes me," is a characteristic of Jake's attitude. He falls under three of Choy's (2002) nontraditional traits: financially independent, delayed enrollment, and attends part-time. Jake is the only participant without any children. 


\section{Textural Description of Jake}

Throughout Jake's educational experience he has been a hands-on learner, "some can read a book on how to repair an automotive problem, but for me I need a hands-on approach." Yet, he is a self-described, "lazy student," not applying himself too often, even to this day, and it transcends to all subjects.

School was not necessarily a priority growing up, but a necessity, "I didn't have the option to drop out when I was younger, it was just the way it was." Always knowing he would join the military after high school, Jake could not rationalize ever dropping out anyway, "you can't always work at McDonalds." However, he did not ever have a desire to excel in school. Jake began in higher tier courses (reserved for high performing students) when he was in middle school, but as he got older he dropped, “not down too far, I kept decent grades, I just didn’t apply myself $100 \%$."

Jake's recollection is that he really only enjoyed two courses during this k-12 experiences: a science and English class. Yet, it had nothing really to do with the course, it was two extra credit assignments that he recalls. The science teacher allowed him to conduct extra research on dinosaurs and the English instructor allowed him to write his own book, which ended up getting published in his town's local newspaper.

It is clear Jake never lacked the intellect to excel in school. This is evident in the fact that after he took the entrance exam into the military, he had his choice of any specialized branch of service, "anything except nuclear technician," he smiles. Jake ended up choosing construction battalion, or CB's. However, after two-years in the service, Jake was medically discharged for a litany of wounds suffered while on active duty. 
Once he came home from being discharged, he moved into his own apartment and began working odd jobs. He landed as a wind turbine technician, but the economy soon crashed; what we now call the Great Recession. Jake lost his job an did not work for several months, "I got bored, and thought I should go back to school because I don't believe in unemployment, and in all honesty that is why I returned: boredom."

Entrance into SCC was easy for Jake (at least the enrollment process). Janet and Stacy from financial aid were very helpful to him (Janet and Stacy will reappear later in Jake's descriptions). However, Jake had been in school for almost nine years and was placed into developmental courses due to his entrance exam scores, "I knew I was doomed from the start."

\section{Structural Description of Jake}

Mentioned earlier, Jake's parents never graduated college, and the idea of graduating college does not excite him, "I may not even attend graduation and to be honest, I didn't even tell my parents I was enrolled in college; they only found out when my high grades were published in the local newspaper."

Jake's experience with faculty has been a "normal" one, with the exception of one incident. He details a story of how a professor spoke down to him in front of the class, which prompted Jake to threaten the professor with violence. Nothing ever came of the situation, except an apology from both men to each other.

Janet, from SCC's financial aid department, has played a critical role in Jake's experience. Janet's two sons are active military so she has taken it upon herself to help veterans that come through SCC's door, "the VA (Veteran's Affairs) can be a bureaucratic nightmare, but Janet has taken that stress away and handles a majority of that paper work for me." 
Helpful advisors have been another area in which Jake expressed his satisfaction with SCC. He expressed his appreciation of advisors helping find courses that fit his work schedule, but also going so far as to recommend instructors that correlate with his "hands-on" learning style. The majority of courses Jake is required to take are only offered during the day, "I am not at the college past 3 p.m.," Jake states, but he must travel directly to his construction job, which can be stressful, Jake explains, "I'm not getting home from work until 9 p.m., dead tired, and then trying to fit in home work is tough."

Even at 28, Jake feels there is a significant age gap among his peers. SCC does provide a veteran's lounge, only accessible to vets who would like a quiet place to study and relax, Jake explains that he is "friendly" with other students but "I think it helps not to make friends because it could turn into a distraction." Jake sees his time in college as a "job" and he is there for work not to socialize.

\section{Textural-Structural Description of Jake}

The veteran's lounge has been a refuge for Jake (Figure 23). The personal atmosphere that the room emanates allows Jake to get away from the noise of the college and to be able to relax. Although we never delved into this medical discharge, it is evident from out interviews that Jake harbors some lingering issues with his military background. He sees the lounge as a "controlled environment" and details out that if he was in college "chow hall" that there are so many variables that he needs to take into consideration, he explains, "in the chow hall you can't watch everyone at once, there are so many entrances that I don't know about. In my mind, I wonder if something is to happen, I can go here, here, or here..." 


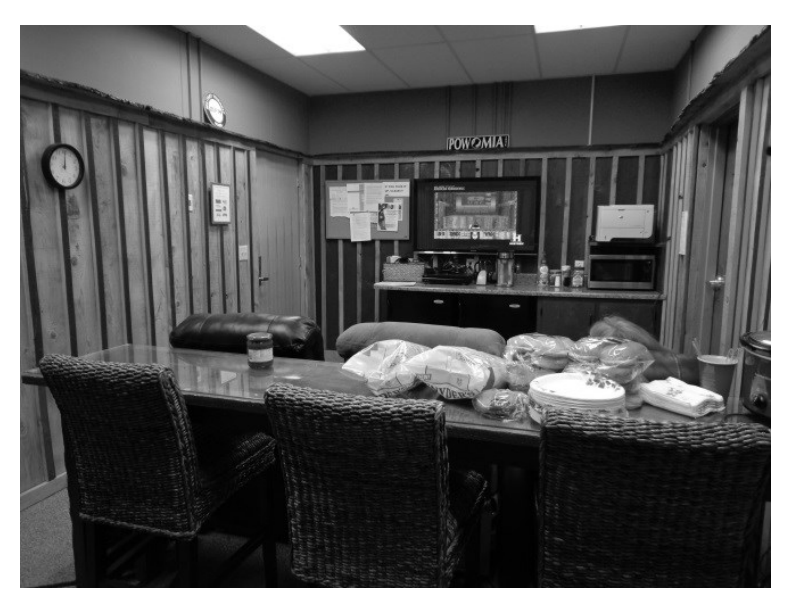

Figure 23. Solitude

The lounge is another great place for Jake to study and to be able to focus, as opposed to the library where he may "constantly look up and get distracted." Jake likes to separate home from school, meaning he does not like to study at home, which makes the lounge his main study area.

Janet (Figure 24) has been a tremendous help to Jake throughout his time at SCC. Jake laments on all the paper work required for government institutions and the VA is, unfortunately, no different. For Jake, the thought of having to do all the paperwork would have been enough for him not to ever enroll in college. However, Janet has taken much of that stress away from Jake and has walked him through each part. Janet has gone beyond her roll as a financial aid officer and has help Jake with personal issues or school problems, not related to financial aid. 


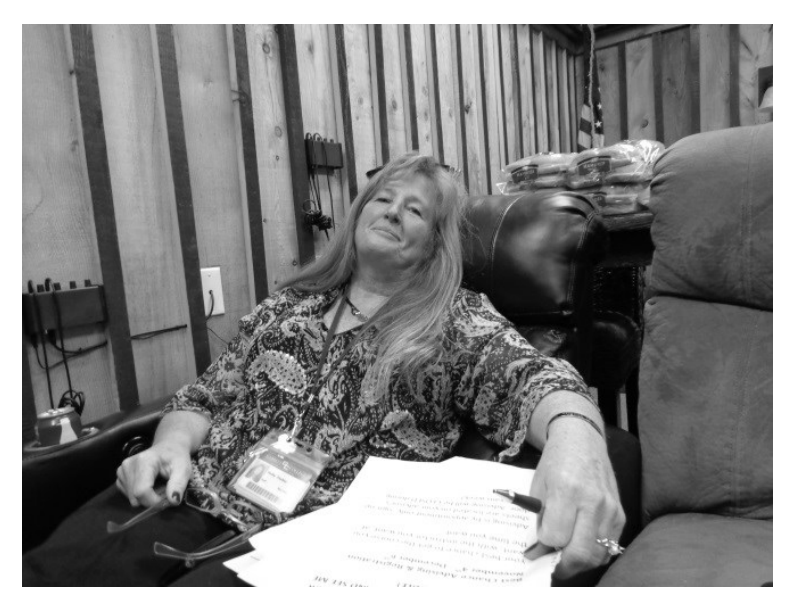

Figure 24. The Very Best

The thought of going to a larger institution causes Jake some concern. He is worried that there will not be another Janet at his next institution that will help him as much and simply the sheer size of another college is worrisome (Figure 25). The simple picture of the SCC parking lot shows the ease of access from one building to the next at the college. Jake talks about visiting another larger campus once and the sense of being lost was a constant fear, "I didn't even know how to get back to my car," Jake half-jokingly states.

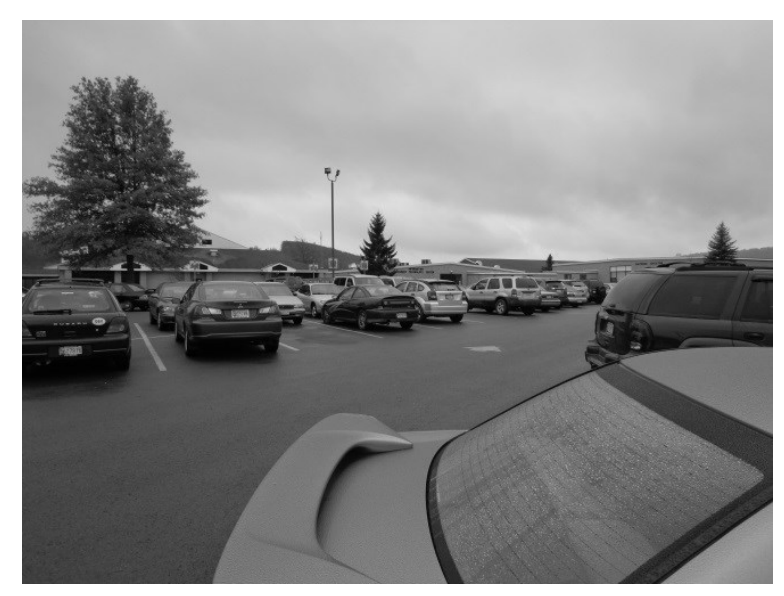

Figure 25. Ease of Access

Jake, as with all participants in this study, has not taken advantage of many student services. Financial aid and the veteran's lounge are the only two areas he uses on a regular basis. 
"Education is a job," Jake states bluntly, he is not sure what will happen after SCC, be it a job or continue onto a four-year institution. However, this thought brings him to a service that is not offered: career or job placement service. He explains that he has never heard of any services, but would like to utilize them if they were available.

Relaxation and the time to reflect on life are represented in pictures of Jake's house and this four-wheeler (Figure 26). The chance to escape work and school is something he values in life and an opportunity for him to "clear my head."

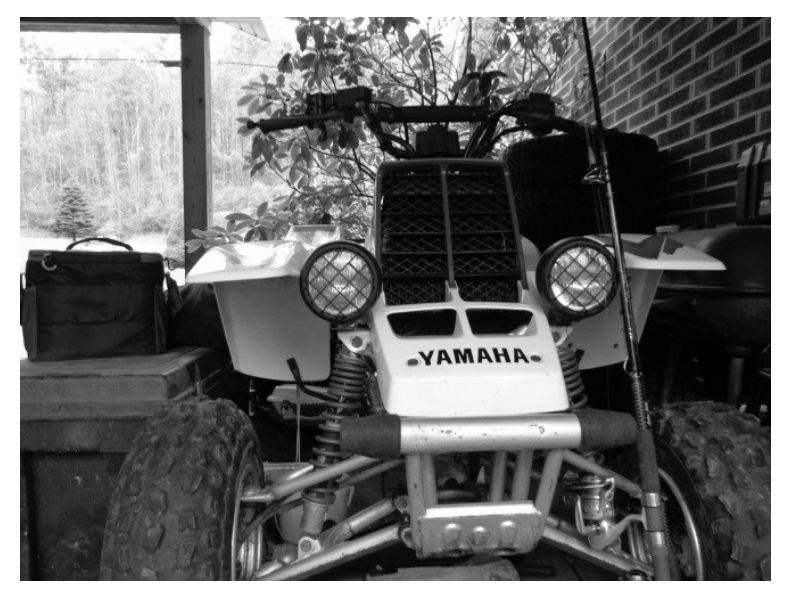

Figure 26. Relaxation

Jake's straightforward attitude describes education, as he has done throughout the whole interview process, as a "stepping stone." He sees it has a way to prepare him for his future job, but does not see college as real life, stating 'in college I can miss some classes and be ok, but if I was at work and miss a couple of day, then I don't have a job." And his direct answers further reflect his rationale for persisting until graduation, "the degree...it's the end goal. There is not hidden agenda, it is the only thing keeping me going, just getting that degree." It is no surprise for those reading Jake's descriptions that he chose Janet as the one picture that represents his college experience while at SCC. 


\section{Participant 6: Roland}

\section{Biographical Information}

Roland is the oldest participant in this study at 51 years of age. He has been divorced once and is currently remarried. Through both of his marriages, Roland has had children. He is majoring in Social and Behavioral Science, with the intent to obtain a counselors job. Roland, like Jake, is a veteran but has had a much different experience during his military career. Besides taking occasional maintenance jobs, he does not have a full-time job; instead Roland chose to quit his job and focus solely upon college work. Roland has four nontraditional traits according to Choy (2002): financially independent, has dependents, delayed enrollment, and attends part-time (Roland was part-time until his final semester, that is when he quit his job and became full-time).

\section{Textural Description of Roland}

Growing up around the rural SCC community, Roland had a difficult upbringing, which impacted his educational experience. Growing up in an alcoholic and abusive home, schooling was not a pleasant time in his life. Roland details that most days of the week consisted of him and his siblings waiting in the car while their parents drank in the local bar. There was virtually no support academically during this childhood.

Due to his socioeconomic status, Roland was frequently picked on at school, because, "I didn't have regular clothes, my mom would sew different pants together to make them longer or shorter," recalls Roland. He painfully recalls another experience, where just before the start of the new school year, his dad took him to buy shoes. Roland entered the thrift shop with the instruction to only spend fifty cents on shoes, but ended spending one dollar, "I got a terrible beating for that," remembers Roland. 
Roland recalls doing fairly well in school, considering the circumstances at home. Much of the academic support he received came from his sister. When he entered high school that is when he discovered shop and masonry classes. He excelled in these classes, opening up the opportunity for him to compete in trade competition (e.g., mechanics and masonry), "that got me out of classes and they just shoved me through the system, because they didn't see me as college material."

It wasn't until the $11^{\text {th }}$ grade that Roland was encouraged to think about going to college. His science teacher believed that he could go to college and "that woman is the first person to ever put the idea of going to college in my head," smiles Roland. The idea that someone recognized his ability outside of being a carpenter, made his self-esteem increase more so than ever before in his life.

The abuse from home continued until Roland ran away from home at sixteen. Having to live in a junkyard, he occasionally went to school, but his absences did not affect his grades too much being in the trades. He recalls the day he dropped out of school to join the military:

I went into a class, and some kids started picking on me and I just got up and left my books on the desk and the teacher was yelling after me and the principal met me at the door and tried to stop me, but I just kept on walking. However, Roland was only seventeen at the time, so he needed his estranged father's signature to allow him in. Roland's father was a veteran, so he willingly signed off for his son, "I think that was the first time he was proud of me," Roland states.

Stationed in Germany, Roland excelled in the military, receiving numerous awards, which did wonders for his self-esteem. That is where his commanding officer advised him that if he ever wanted to get ahead in the service, that he would need to go back to school. So, Roland 
at the age of twenty, re-enrolled in high school to finish his senior year. This time around was different, all the other students were "respectful, no pettiness," remembers Roland.

Roland got married and had a child while living in Germany. His intention was to reenlist and become a helicopter pilot, but his wife's mother got sick and they all moved back to the States. However, when he returned home he began drinking with this dad, and soon fell into alcoholism. As the years past, he got divorced and his father passed away, "when he died and with all that history, I still balled like a baby."

After years of going from job-to-job, Roland decided to write a letter to the VA to try and receive help from their organization. The letter consisted of his troubled past, which influenced a staff member at the VA who pushed the agenda that helped get Roland into college.

\section{Structural Description of Roland}

The VA allowed Roland to enroll into college under a plan called Chapter 31; which is considered hardship. Roland was excluded from the educational benefits of the G.I. Bill because he had been out of the service too long and had never seen combat. He made various arguments as to why he should be eligible, but the strongest argument he felt, was the fact that he was unable to protect himself against his construction partner due to his lack of education. By protect, Roland meant that his partner overcharged clients and was able to place blame upon Roland. Roland feels that if had been educated that never would have occurred, "I was just coming into this partnership with a high school diploma, and I didn't have the education to handle a large business...I just wasn't equipped educationally.”

Initially Roland pursued a degree in education once he entered SCC. However, he soon realized that the surrounding community was not an area hiring many teachers and he would 
more than likely have to relocate; for Roland, that is not an option, "I have a mortgage and other family responsibilities here, I cannot just pack up and leave."

The VA covers all of Roland's education and he takes out student loans to help with living expenses, "I only live on $\$ 750$ a month. It is very hard sometimes." He goes on to talk about a typical month and expenses:

I'm four months behind on the mortgage and once I get that caught up, then I need new tires, so that another $\$ 800$. There are other things that we need, but just don't have the money for, like a washer and dryer. Every time I get a student loan I try to buy an appliance for the house or fix something broken.

Roland would like to not have to take out so many loans, which is why is upset by the fact that he does not qualify for many, if any, grants. "I don't have my mom and dad to help me search, like many younger students and I am only $20 \%$ disabled and the VA requires you to be $30 \%$ disabled to qualify for more assistance." This lack of funding is a stressful topic for Roland to discuss; he feels many of his problems would be alleviated if he were eligible for more grants.

His medical conditions consist of high blood pressure and low testosterone, which require weekly shots. Roland's medical issues have impaired this educational experience while at SCC. Before he was diagnosed his grades suffered, but now with his medication his grades have stabilized.

Supportive and helpful staff has been a major contributor to Roland's success at SCC. He recalls when he first started college he worked with Carrie, who helped explain how much work and dedication this time will take, "and that made something click...I'm going to have to work for this." Roland was taught study skills, something he believes that all nontraditional 
students should be provided, "there is an assumption that everyone knows study skills or how to work a computer...not everyone knows."

When the idea that college would be difficult for Roland he quit his job. He had to make a decision if he wanted an education or "the dollar." He understands that if can obtain his degree he can get a better job and will not have to work "out in a snow drift or ditch or be 70 years old working on a roof, like my dad did...I don't want that to be me."

Roland's interaction with other students has been one of distance, "I can understand, they see an old guy and want to know what's the deal with this guy..." He has found it difficult to befriend anyone, but he does not consider that any issue. Yet, Roland has made efforts to create study groups to help with certain classes.

Family life has been a struggle since returning to college. Roland calls it a "tug-o-war," with finances, trying to keep his youngest daughter structured, and his wife was laid-off; and that extra income made life a little less stressful. However, Roland's youngest daughter has been very encouraging to him returning to college and she hopes to attend SCC after high school. She has been another motivating factor for Roland to attend and finish college, "I hope I can put money aside for her education, I have never had the opportunity to do that yet in my life."

\section{Textural-Structural Description of Roland}

The financial aid department (Figure 27) has helped Roland through his entire time at SCC. Even though he has had a difficult time with the VA, the staff has guided him and gone "the extra mile." Roland tells a story of how he did not have enough money to buy his daughter a dress to go to a dance, so a staff member from the financial aid department bought her one with her own money, "it is stuff like that...it makes me want to cry. They are always asking how I am." He sees this staff as going above and beyond their job responsibilities. 


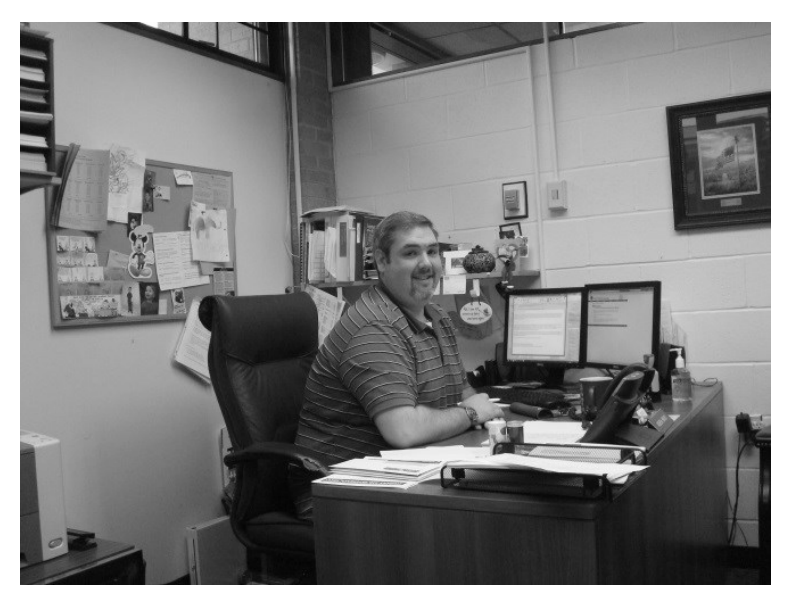

Figure 27. Helpful Staff

Figure 28 is a picture of Carrie (mentioned earlier). She is considered one of Roland's best experiences at SCC. Carrie helped Roland with his study skills and stressed the significance of the hard work to come, "when I came back I was out of school for almost 30 years and she helped me navigate the waters."

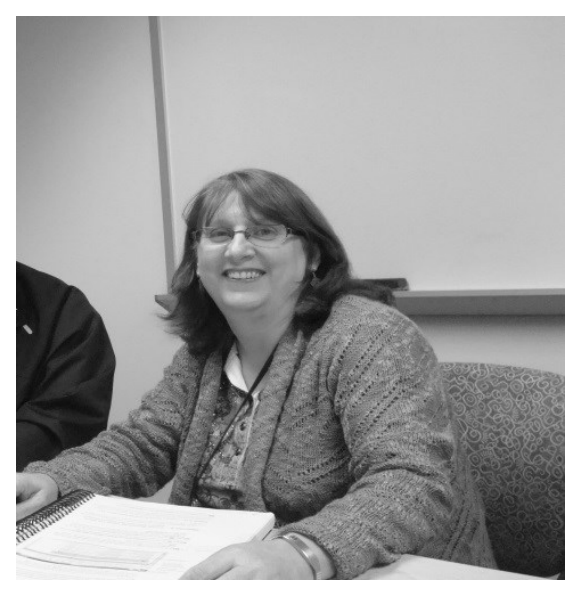

Figure 28. Best Experience So Far

Figure 29 is of a faculty member at SCC. Roland took multiple pictures of faculty during this project, which was a reflection of not just academics but helpful individuals and concern for students. For example, when Roland struggled with math, a faculty member would meet him outside his normal office hours and even on the weekends at the college. Likewise, the faculty 
member pictured in Figure 29 helped Roland complete his courses when he was in an unfortunate car accident, putting him out of the college for weeks. Roland stresses that these multiple pictures were about "the people." Throughout his troubled past, he never experienced a large group of people that have gone out of their way to be so helpful.

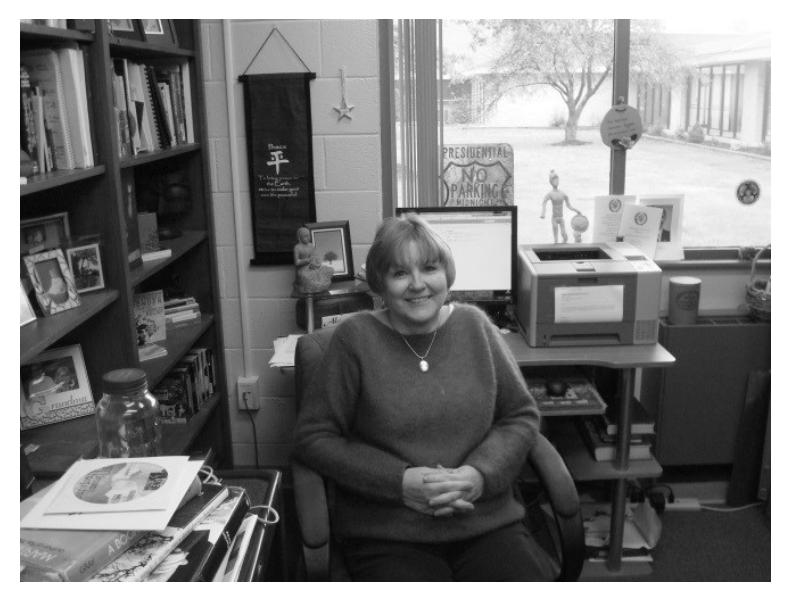

Figure 29. It's About the People

The VA (Figure 30) has been a benefit to Roland's experience in college, but his experiences with the VA have also been negative. On one hand he would not be in college without the assistance of the program. However, he wrote letters for years to the organization in an attempt to go back to school, which, in his opinion, hindered the progression of his professional life. Additionally, he feels the VA does not adequately process veterans benefits, "it can be weeks overdue before I ever get my educational checks." During the time of this project the U.S. government was shutdown, which impacted the VA. In turn, Roland's VA benefits were delayed and he had to have other plans in place if he was to be dropped from the college due to unpaid balances.

Although there is a veteran's lounge at SCC, Roland does not use this facility. For him, the age difference is a big factor for not attending the lounge; on average he is 30 years older than most veterans at SCC. This age gap and generational differences has driven him away from 
the benefits the lounge provides, "I'm just into socialization, not even young vets... and in all honesty, their language is something I don't like to be around."

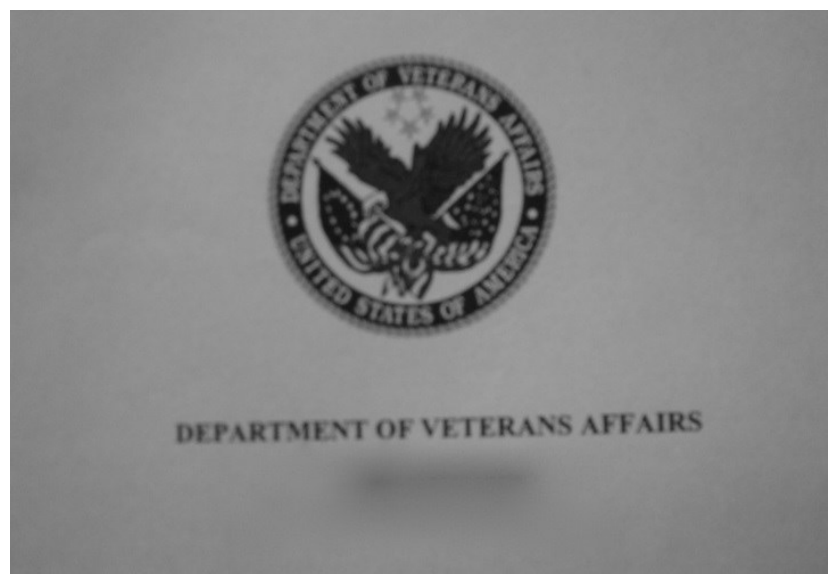

Figure 30. Pros and Cons

Hunting plays a significant role in Roland's experience in college (Figure 31). For Roland, "it's an out," from all the stress of college and a time to reflect; it is something he looks forward to all year. Although reluctant to admit, he sets aside some of the money he receives from his student loans to get a deer mount.

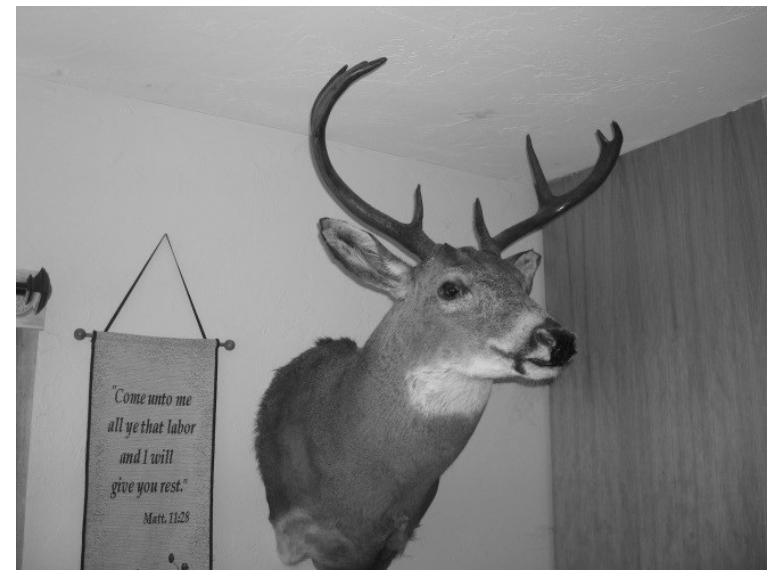

Figure 31. Reflection Time

Roland's daughter (Figure 32) was an inspiration for him to write the letter that finally got him his VA benefits. His daughter was a focal point in this letter, in which he stressed the 
point of not having a good job and how he still had time to go back to school to get a better job and begin saving money for retirement and his daughter's education. "I want to set an example for her, so that she will want to go to college and hopefully I will be able to pay for her college," Roland expresses. Roland occasionally brings his daughter to the college, in hopes of getting her excited about college. This is important for Roland, whose dad only completed the $5^{\text {th }}$ grade and his mother the $9^{\text {th }}$.

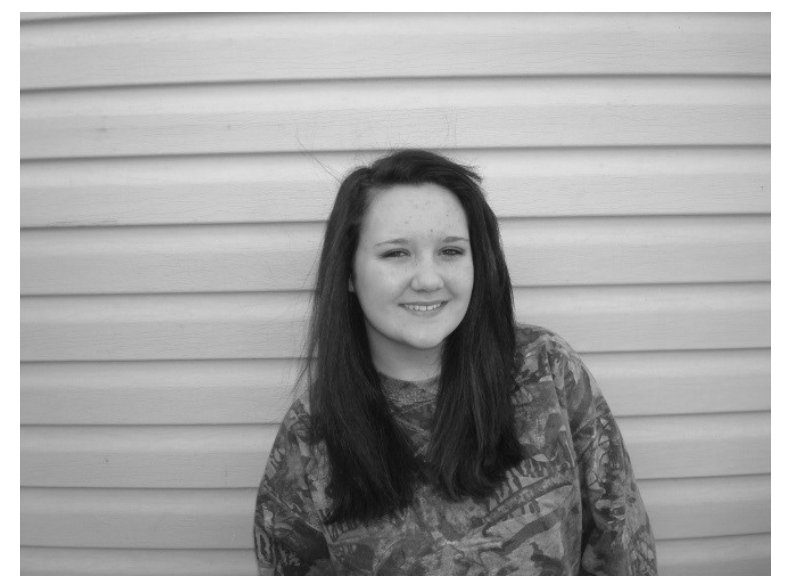

Figure 32. Family Inspiration

The opportunity for an education changes everything, according to Roland. He laments on the past, wishing he would have had a better upbringing and the chance for a better educational experience. Attempting to run businesses in the past failed because Roland feels he was not well educated, and if only had he had a better education, then maybe he could have avoided those obstacles, "I really hope my children see what I have done and make an effort and finish college."

"There is a lot riding on this," is Roland's comment to why he stayed in college. With any project he has started he has finished, and this experience is no different. The desire to set an example to his children, but also the sense of accomplishment is additional motivating factors. 
Carrie's picture (Figure 28) captured Roland's experience at SCC. Roland senses that he was "drowning" when he came to college, but she "was the life preserver." Although his daughter was the impetus to write the letter to the VA, it was Carrie's guidance that persuaded him to stay in college.

\section{Summary}

Throughout this chapter, readers were introduced to six participants and their educational experiences. Each participant's experience was described texturally and structurally: the "what" and the "how" of their life events. Sequentially, in Moustakas' (1994) phenomenological analysis, an individual textural-structural description was provided to capture the essence of each individual's experience. From these experiences, major themes emerged that were exclusive to each participant, yet themes also paralleled each individual. These similarities created four themes that will be investigated in Chapter 5 to provide a "unified statement of the essences of the experience of the phenomenon as a whole" (Moustakas, 1994, p. 100).

\section{Composite Description of Themes}

\section{Introduction}

The intention of Chapter 5 is to provide the essence of the lived experience, in the case of this study, the lived experience of nontraditional community college students. However, with the individual textual and structural descriptions for each participant taken during a particular time and place, and examined by a single researcher, the essences can never be completely exhausted (Moustakas, 1994). Yet, the composite description "is a way of understanding how the participants as a group experience what they experience" (Moustakas, 1994, p. 142). Once 
reading about the phenomenology in this chapter, individuals will be able to "understand better what it is like for someone to experience that" particular phenomena (Polkinghorne, 1989, p. 46). The construction of a composite textural-structural description revealed the essences of the lived experience of nontraditional community college students to be: motivation, helpful/caring faculty and staff, external responsibility, and past educational experiences. Table 5 provides verbatim evidence from the interviews regarding each theme.

Table 5

Themes

\begin{tabular}{|c|c|}
\hline Themes/Meaning Units & Evidence in Participants' Statements \\
\hline Motivation & $\begin{array}{l}\text { "Younger Students don't realize the opportunity } \\
\text { they have...I'm not taking this opportunity for } \\
\text { granted" } \\
\text { "This is a job, I'm not here to socialize" } \\
\text { "I wanted to feel like l'd done something in my } \\
\text { life" } \\
\text { "I want to show my kids that they can be the } \\
\text { best they can be" }\end{array}$ \\
\hline Helpful/Caring Faculty \& Staff & $\begin{array}{l}\text { "There is something special about the faculty } \\
\text { here. Going above and beyond their normal } \\
\text { duties" } \\
\text { "My advisor took interest in me and cared } \\
\text { about how I was doing" } \\
\text { "Staff has walked me through the financial aid } \\
\text { process every year" } \\
\text { "They spent after hours with me" }\end{array}$ \\
\hline External Responsibility & $\begin{array}{l}\text { "Studying at home is tough. Being a single } \\
\text { mom has lots of distractions } \\
\text { "I'm here to take class, then I have to go back } \\
\text { to work or pick up my kids" } \\
\text { "It all plays a role, kids, work, and school" } \\
\text { "The balance of family and work has been very } \\
\text { stressful" }\end{array}$ \\
\hline
\end{tabular}


Past Educational Experiences

"I always found a way out of school and my mom enabled it"

"Education was not valued too much at home"

"My parents never graduated high school"

"Parents could have cared less if I went to college"

Motivation. Participants spoke in length about his or her desire to accomplish their goal of graduation. However, there were various factors that motivated individuals toward this accomplishment. Returning to college and the rationale of persisting until graduation will be categorized into two areas: family and self-determination.

All participants except for Jake (single and unmarried) spoke of being motivated by family, ranging from the idea of being a role model to wanting to provide a better future for their family. The notion of obtaining a higher paying job upon completion is a motivating factor, even for the unmarried Jake. Yet, participants with families, elaborated on the differences between themselves and traditional aged students. For example, Jennifer and Kathy both compared their situations to other, traditional students. Kathy believes that traditional students should not try to come back when they are her age (late 30s) and have family and kids, because it is not easy. Kathy goes on to state that "this is probably one of the hardest things I have had to do, and I have given birth to 3 kids with no meds." Douglas also views traditional students as having opportunities they are not fully aware of. Jennifer, along the same line of Kathy and Douglas, wanted to give some advice to traditional aged students, stating:

I'm sure there are others who have a more hectic life than me, but if I can juggle it, you as a dorm student who have no real responsibility except go to class and study, should have no reason as to why you are failing any of these classes. 
Being role models for their children was an additional motivating factor for the participants. Roland's youngest daughter, who has accompanied her father to campus on numerous occasions, has expressed a desire to attend college. For Roland, his daughter's ambition is a sense of pride because all of this other children have never attended college nor have they expressed interest to ever attend. Additionally, all participants, except Jennifer, are first-generation college students, and the opportunity to show their children that a college education is important is very valuable to the participants.

Determination and goal setting applied to all participants and their desire to return to college and persist to graduation. All participants delayed enrollment into college, from reasons of military commitments to starting a family. Yet, all participants, upon entering college, viewed the experience has a job, not as Jake put it "a time to socialize." Each participant spoke of graduation and obtaining their degree as a major motivating factor to persist to graduation. Jennifer echoed Jake's comment, stating, 'I'm not here looking for life-long relationships, I'm here to complete my goals and move on." Furthermore, the goal of a degree, which can transition into better employment, was a common thread amongst participants. Both Debra and Kathy had similar statements with regards to their motivation of obtaining a degree. Debra stated, 'I don't want just a minimum wage job, I don't want to ask if people want a shake with their fries or if they want a candy bar the rest of my life." In a similar tone, Kathy wants a "steady job and not have to cook or clean for other people."

Helpful/Caring Faculty and Staff. All but two participants in this study chose a faculty or staff member of SCC as the picture that sums up their experience in college. However, all participants took at least one picture of a faculty or staff member during the data collection phase. 
When discussing faculty and staff, participants spoke in high regards. For example, advisors (which are also faculty) were frequently mentioned with regards to their flexibility. Roland, Jake, and Debra all could recall when scheduling for the upcoming semesters, their advisor would take interest, not only in their academic lives, but their personal lives, as well, "they cared about how I was doing," stated Roland. With their place of employment a concern while scheduling courses, participants spoke of the time and effort put forth by advisors to find what worked for them and their lives.

It is the notion that faculty and/or staff take a genuine interest in their lives is what has contributed to participants to reach their goals. Jennifer, who spoke highly of certain faculty because of their efforts with her son, believes that, "there is some special about the faculty here...they go above and beyond their normal duties. They don't have to do that, they will get their paycheck no matter what." Furthermore, Jennifer credits Stacy (Figure 9) for getting her into college and keeping track of her progress, which, for Stacy, who works in financial aid, is not her job description. Likewise, Roland's experience with caring faculty (Figure 29) came when his car was wrecked and he had to "work hand-in-hand" with his instructor to complete his course work. As for Debra, Kathy, and Douglas, the intangible knowledge taught by professors is what they see as the most rewarding, such as, accountability and responsibility. Debra believes "that is what today's workforce is looking for, and I'm grateful that I have learned those skills."

For Roland and Jake, both veterans, the financial aid department has been instrumental in their success. Janet (Figure 24), SCC's unofficial veteran's affairs officer, has taken upon herself to walk veterans through the paperwork for their G.I. Bill, eliminating the bureaucracy of paper work that Jake and Roland would have to endure. However, this has not been her only role 
in their lives. For example, Janet frequently inquires about their academic lives, but personal as well, "she is an angel," Jake expresses. Roland's experience with Janet goes somewhat deeper. When Roland was short on money, he could not buy his daughter a dress for a school dance. Once hearing about his dilemma, Janet immediately gave Roland the money to buy the dress, without having to repay her.

Although it is the responsibility of admission, financial aid, and academics to assist in the transition of new students, it is not necessarily their responsibility to facilitate their growth and take an interest in their lives. The hours spent outside of the classroom and on weekends, by both faculty and staff at SCC, to help the participants with both college related and personal issues, demonstrates the crucial role they play in the success and persistence of the participants.

External Responsibility. Family, work, or both were a factor in each participant's life. As mentioned earlier, Jake was the only unmarried participant and each participant had a job, either part- or full-time (Roland quit his job the last semester of his studies). These various responsibilities, from driving back and forth from campus to work, or having to get children ready in the morning to go to school, or finding quiet time to study at home were all important factors for participants as it relates to their college experience.

Although families have been supportive of all applicable participants, the added responsibility of going to college has caused each respective individual a varying degree of stress. Douglas, who was married right after high school, has stressful days with balancing school and family, stating, "it has shook up the family schedule." He continues that his wife sometimes does not see the end benefit of going back to school, which causes the occasional argument between the two. Kathy believes the missing variable is time, stating "had it been just me and my husband there would be no problem, but having three children under the age of 12 
makes it difficult." Likewise, Debra views her situation as having "more responsibilities than anyone I know." Being a widow, she does not have spousal help with chores and taking care of her children, which makes finding time to study a struggle. According to Debra, she never has "peace and quiet at any given time while at home," requiring her to study either very earlier in the morning or very late at night.

A job, as with family, has impacted each individual in this study. Outside of Douglas, who is going back to school to increase his value with his current employer, and Roland, who is currently unemployed, each participant has a part-time job. However, the reason for coming back to college for each one (except Douglas) is to get a better job; each participant knowing that the attainment of at least an AA is necessary for a higher paying job. Yet, that is for the future. Currently, those who are working find the balance a struggle, as with family. For example, finding courses that are offered at various times throughout the day are at a minimum at SCC, which, in turn, requires participants to occasionally take time off from work to take required courses. Even when a course does not interfere with their job, the time of day can cause additional stressors. For Jake, who must take the majority of courses in the day, leaves straight from campus to his construction job, not returning home until 9 p.m. most days of the week, "and then I have to get my school work done and that is struggle," Jake concernedly expressed. Jennifer has had a similar experience to Jake, she has seen the work/college balance as a challenge, which is even more telling, due to Jennifer working on the campus of SCC.

Although, external responsibilities could be a factor of motivation, the depth and importance of this theme warranted its own thematic section. With the addition of college responsibilities to their external commitments, participants have had to learn time management and flexibility. Due to each participant's commitment to work or family has restricted them from 
taking part in most college campus events and any study group related activities. There was not a single participant who took advantage of peer study groups or any campus event. External responsibilities take participants away from campus once their class time is done. However, individuals like Douglas, Roland, and Kathy expressed their aspiration to, if time would allow, meet with their fellow classmates to study.

Past Educational Experiences. Mentioned earlier, each participant, outside of Jennifer, is a first-generation college student. Furthermore, participants had a varying degree of similar experiences in the past. Besides, the first-generation moniker, Kathy, Debra, Roland, and Douglas all described past homes lives as one that were not conducive to the value of education. As for Jennifer and Jake, their families emphasized education during their past. Yet, Jake's military upbringing provided the opportunity for only two paths after high school: college or the military. Jake never recalls any ordeal with family and education, just "a necessity" to get out of the town he lived in. For Jennifer, with college-educated parents, school was valued, but upon high school graduation her future husband persuaded her to not to follow that course of action.

Kathy and Debra experienced similar household attitudes with regards to the importance of education while growing up. "School just wasn’t a priority," stated Debra and "my dad just said marry a doctor and you'll be alright." Comparably, Kathy’s parents were not active participants in her education as a child, and "they could have cared less if I went to college or if I worked at Burger King my whole life.” For Douglas, growing up on a farm made the physical labor a high priority for him and his family. Although his parent's empathy for education was not to the extent of Kathy and Debra, Douglas' parents valued labor over education. Neither Kathy nor Debra mentioned it, but Douglas believes that due to the fact that his family was successful without a college education made their view of education and college one of 
unimportance. As we heard from Roland during his textural and structural experiences, he had a very difficult upbringing. His family experiences made education a difficult process, which translated into no educational support at home and, in turn, an eventual drop out from high school.

Kathy and Debra were married within a few years out of high school, and Jennifer was married upon graduation, which placed their college education on hold. Each of the female participants admitted that education was "always on their mind" while they were married. Although their husbands did not specifically tell Kathy and Debra they should not go back to college, they did feel obligated to be stay-at-home mothers. However, Jennifer experienced a controlling husband who demanded that she not attend college due to where they live (which a college degree is apparently not necessary) and the cost of attending. Jennifer admits that she is embarrassed for "not sticking to my guns to go back to school until now."

\section{Summary}

Utilizing Seidman's (2013) three-step interview process, participants illustrated their educational experiences in relation to family, campus staff, personal qualities, and past occurrences. Additionally, following the steps indicated in Moustakas' (1994) modified StevickColaizzi-Keen method of analysis, data was analyzed and presented. Participants actively created new knowledge through a reflective process to create a collective meaning of a nontraditional student education experience. Through the essences manifested during each interview, participants demonstrated attributes that have driven them to not only return to college, but to persist until graduation.

Chapter 5 will present a discussion of the significance, implications, recommendations, and conclusion. 


\section{Chapter 5: Discussion and Conclusions}

\section{Summary of Study}

The purpose of this research study was to explore the lived experiences of nontraditional community college students in relation to their education. This exploration allowed me to follow how nontraditional community college students experience education with relation to internal and external influences. Furthermore, I investigated how administrators could use student perspectives to modify institutional policy to retain this student population.

To better understand the educational experiences of nontraditional community college students, current students who had at least seventy percent of their program completed were sent a letter of interest via email and eventually chosen through purposeful and comprehensive sampling. The study utilized a social constructivist lens to gain a deeper understanding of nontraditional students' lived experience. The criteria of the sampling was based of Choy's (2002) definition of a nontraditional student: (1) delayed enrollment; (2) attends part time; (3) is considered financially independent; (4) works full-time; (5) has dependents other than a spouse (usually children, but sometimes others); (6) is a single parent (either not married or married but separated and has dependents); (7) does not have a high school diploma. Based off these traits, individuals in the study ranged from having two to four characteristics.

With nontraditional students entering college in higher numbers, it is important that community college leaders better understand this student population. Using quantitative methods to survey students is standard when it comes to understanding a student's motives: from dropping out of college, to satisfaction with the campus environment. However, employing qualitative methods can provided a deep, rich look into the lives of those participating. 
Implementing a phenomenological methodology can provide students an opportunity to reflect and expand upon their lived experiences to better serve the institution as a whole.

Using a phenomenology as a methodology, the six participants' life-world descriptions were collected and analyzed. Data was collected through interviews following Seidman's (2013) three-step process and through the use of photographs taken by the participants. The three-step process focused on the life history, details of the experience, and reflection of the meaning. All interviews were semi-structured and participants kept a journal to record their thoughts on the pictures they chose to capture. Data was analyzed through Moustakas' (1994) modified StevickColaizzi-Keen method of analysis.

\section{Discussion}

\section{Introduction}

This study explored the educational experiences of six individuals who provided a rich understanding of how they construct their view of college. By listening to the stories of students who have experienced the phenomena provides critical insight to the realities these students face. As participants reflected on the educational experience, it became evident that various parts of their lives, on and off the campus environment, affected the entire experience.

Participation allowed students an opportunity to share their life experiences in relation to their time in college. They were able to provide a colorful picture of the experience, which offered a shared meaning (Mapp, 2008). During our conversations and reflecting on photographs, four essences, or themes, emerged from the composite lived experience of participants: motivation, helpful faculty and staff, external responsibilities, and past educational experiences. The opportunity to learn more about these essences provided me an opportunity to take an in-depth look into the lives of unique, yet similar, individuals. Discovered during our 
time together I learned about men and women who cared deeply about their education, family, and genuine faculty. Moreover, the themes revealed in this study echo some similarities identified in the literature as components of nontraditional students experiences in college.

Using phenomenology as a methodology provided individuals an opportunity to gain a deeper level of understanding of their time in college and the factors that impacted the experience. Constructivism, as with phenomenology, suggests "that we are proactive co-creators of the reality to which we respond" (Barkway, 2001, p. 192). In a phenomenological study, the goal is to understand individual experiences and, in the end, paint a shared meaning. Likewise, the construction of meaning from a social constructivist view focuses on the individual as it is influenced by his or her surroundings.

The discussions in the following sections will elaborate on themes discerned from the participants in this study. Bringing the themes of motivation, helpful faculty and staff, external responsibilities, and past educational experiences back to Choy's (2002) characteristics, is a fundamental step to better understand nontraditional students and provides the ability to add to the national dialogue of this student population. Furthermore, this study is intended to help inform administrators on policies to help better serve nontraditional students. With the rich, diverse backgrounds that make up typical community college students, leaders must understand their various constituents in order to serve them properly. Supported by findings in Kasworm, Polson, and Fishback (2002), college leaders must separate the needs of traditional students with the assorted needs of the nontraditional. In turn, the stories told by Kathy, Jennifer, Douglas, Debra, Jake, and Roland provide the reader with detailed vignettes that can be used to inform a wider college dialogue. 
Motivation. Determination, the desire to make a better life, and the desire to for a better job were main motivating factors gleaned from the textural and structural descriptors of the participants. Kathy's uncertainty about the closing of her video store or Roland's opportunity to provide a stable home for his family are examples of this determination mind set. As with Apps (1981) and McGivney (2004), I found that the participants had more purpose and clearer goals when attending college. For example, Jake and Jennifer each viewed their time in college as a job and did not worry about the socializing aspects of campus life. Furthermore, although they have many variables to balance on and off campus, participants displayed a personal drive that has helped them overcome pressures to persist. I found that this personal drive manifested itself in the form of supportive family and within the self of the individual.

Cross (1981) described adult students has having the potential for a dispositional barrier, which means that a student's view of his or her self (e.g. too old, poor performance in the past) would hinder them from staying in college. However, participants in this study proved differently. Although there were instances when the participants felt discouraged by their deficiencies in study skills, lack of time to dedicate to school work, and feeling somewhat intimidated by younger students, their ability to set goals was a catalyst to push them through those moments of self-doubt. Jake, Debra, and Roland spoke in length about how they felt underprepared when they returned to college. However, all three spoke of going the extra step of getting additional help to learn strategies to study and acquire skills that were conducive to their learning styles. Additionally, Kathy and Jennifer felt intimidated by their age among younger students. Yet, they too were able to see past this barrier to move toward their goals. Motivation, or any variation of the term, is not included in Choy's (2002) nontraditional student criterion. However, this theme was a central concept for the participants in this study. I 
found individuals expressing some form of motivational factor, from making more money to having a feeling of self-worth to providing more financial security for their family. In contrast to Choy's (2002) traits, motivation can be a key component to adult student characteristics. Similar results were concluded from Knowles, Holton, and Swanson's (2011) definition of motivation, which stresses that adults are motivated by "some external motivators (better job, promotion, higher salaries), but the most potent motivators are internal pressures (the desire for increased job satisfaction, self-esteem, quality of life)" (p. 67).

The sense of accomplishment and making their family proud was a common thread among most of the participants, as opposed to the practical reasons for staying in college. Chao and Good (2004) found similar notions of success in their study, in which they described the "rewarding nature of college" (p. 8). Throughout our interviews, I found participants spoke of how obtaining a degree and finishing what they started made them feel good about themselves about not giving up. This may relate to the fact that each participant, at some point in his or her lifetime, had given up or had been forced to give up some aspect of their lives. It was discovered in the interviews that, in some way or another, individuals' experienced abusive parents, failed marriages, job loss, or had major injuries. Yet, all expressed that they have a job to do at the college and they would not give up their chance to graduate. While I listened to their past stories, I developed a deeper appreciation of how all of their life experiences played a role in who they are today. These interviews have provided me something that most faculty and/or administrators never have an opportunity to experience: to get to know their students.

Participants' motivation to stay in college can also be attributed to their goal setting skills. Participants stressed the fact that they were not in college to socialize; they were there to obtain their degree and move on. The lack of socialization was not any attempt to alienate 
themselves from other students or the campus, but the fact that jobs and family pulled them away from these opportunities. Similarly, Kasworm et al. (2002) found that nontraditional students "view college as a means to an end - to their future life status - rather than on the collegiate journey" (p. 24). In contrast, traditional students are typically motivated to enter college as the next step in life after high school.

Helpful Faculty and Staff. "It was the human contact that made the difference," (Levine \& Nidiffer, 1996, p. 65). This quote summarized the author's study of first-generation college students and is a concise quote for this particular theme of helpful faculty and staff. As with motivation, helpful faculty and staff is not seen as a criteria for Choy's (2002) definition of nontraditional. Although this theme is not a characteristic of an individual from the study, it is a major component of the experience for the nontraditional student. For example, there was at least one picture taken of a faculty or staff member from SCC during data collection. Journal entries regarding these pictures produced comments such as "encouraging," "interested in my success," and "genuinely caring." This theme was somewhat of a surprise to me, due to the findings from the pilot. In the pilot study the two participants never spoke in length of any type of accolades for faculty or staff. However, the profound impact of faculty and staff on the six in this study shed light onto the importance of not only academic support, but emotional support as well.

The importance of instructional practices and nontraditional students has been researched in various studies (Schunk, 2000; Valadez, 1993). However, the importance of a knowledgeable instructor never came to the forefront during our interviews. I found that individuals were more inclined to talk about the friendly and supportive nature of their instructors. For example, Douglas and Jake both spoke of how their advisor took interest in their success and helped find 
the schedule that would fit their busy lives. Additionally, Roland and Jennifer detailed their praise of particular staff members who helped them with not only their schoolwork, but with family issues as well. This supportive trait has been called validation. Validation, as defined by Rendón, (1994) is "an enabling, confirming and supportive process initiated by in-and out-ofclass agents that fosters academic and interpersonal development" (p. 44).

Persistent research studies have frequently focused on issues outside of class, which this one does. However, this study is concerned with the total experience, not just internal or external issues. Due to their busy schedules, class time was where participants spent the majority of their time while on campus and interacting with faculty. As mentioned earlier, through our interviews I found that our discussion frequently went to the idea of caring faculty and staff that took genuine interest in their educational process and goals. Moreover, these particular college employees would inquire about them personally. Academic and interpersonal forms of validation are reinforced by Barnett (2011) and Rendón, (2002) who found that community college students benefited from a supportive campus environment which purported such traits. Additionally, Rendón and Jalomo (1995) found validation to increase persistence in community college students.

The faculty and staff mentioned throughout the interviews took the extra effort to learn more about the participants and take a genuine interest in their academic goals. One can argue that those steps have helped the participants stay in college. The most prominent example of this idea is from Roland's final interview. When asked to choose a picture that summed up his experience as the college, Roland immediately selected Carrie. Carrie is a staff member who provided guidance and skills to Roland that, according to him, "kept me from drowning." Unsupportive institutional agents such as faculty and staff are seen as institutional barriers 
according to Cross (1981). Additionally, Schreiner, Noel, Anderson, and Cantwell (2011), found that within community colleges, students spoke of how faculty and staff "respected them, had faith in them, and believed they could succeed" (p. 331), which contributed to their persistence.

Many nontraditional students have been out of, or have never been in, the college system. Through our interviews, I found that individuals were, at least initially, not familiar with the expectations and regulations of the academic setting. Kathy elaborated on not understanding the amount of time she would have to dedicate to studying for her classes and Douglas shared his concerns with the difficulties of applying for financial aid and grants. Apps (1981) found that the bureaucracy associated with campus routines can overwhelm adult students. It was evident from our discussions that these students needed more guidance and validation than a traditional student, who typically has been in the educational system for a continuous time period and understands how the system works.

The opportunity for me to listen to the six individuals share their sincere care for those faculty and staff who have helped them throughout the years has provided me a chance to step back from my role as an instructor, advisor, and administrator and reflect on my own practices. Even though our lives while working in higher education can become inundated with various responsibilities, the obvious profound impact that this theme has upon students warrants taking take the time to provide caring assistance.

External Responsibility. Adults spend more time dealing with external responsibilities than younger students (Slotnick, Pelton, Fuller, \& Tabor, 1993). The theme of external responsibility in this study encompassed various aspects of Choy's (2002) criteria on nontraditional students. For example, being a single parent, having dependents, working full time, and attending part time all attribute to external responsibilities. Each participant in this 
study had a full- or part-time job, has dependents, is a single parent, or attends part time. These traits led all participants to state that their primary goal while on campus was to attend class and not to socialize. Simply stated by Debra during our second interview, "my concern is doing well in school, not what other kids think of me."

Situational barriers (e.g., family and jobs) can threaten success in college due to multiple role demands (Cross, 1981). The lack of time to dedicate to campus related activities such as study groups was a frequent comment made by participants in this study. Douglas wanted to collaborate with fellow students in difficult subjects like Chemistry, but his job schedule frequently prohibited that type of interaction. Likewise, Jake takes classes back-to-back and leaves immediately to go to his construction job. During our discussions, I never felt that these individuals were on campus for any other reason than for academic purposes. Socializing was virtually nonexistent, even social gatherings such as study groups. This sense of separation is supported by Scott and Lewis (2011) who, while conducting classroom observations, noticed that adult students were distant from their younger peers.

Participants reported that the responsibility of going to work or picking up their children was the mitigating factor for not staying on campus for any prolonged period of time. The participants lack of belonging and engagement to the college campus is a concern of institutional commitment (Brown, 2002). This lack of engagement has generated a view of nontraditional students as "fragmented learners who cannot devote sufficient time, energy, and resources to intellectual engagement" (Sissel, Hansman, \& Kasworm, 2001, p. 25). Furthermore, Price and Baker (2012), utilizing the National Survey of Student Engagement (NSSE) as their data collection method, found that the survey was more appropriate for traditional students and that nontraditional students are less engaged socially while on campus. 
Family responsibilities were a major concern for all participants, with the exception of Jake. Even though there was some form of family support for each participant, the notion of guilt became prominent for a few individuals. The thought of being away from spouses and children made participants, especially Kathy, Douglas, and Jennifer, feel as if they were abandoning their families and not doing a good job balancing family and school. This notion of guilt is supported by Fairchild (2003) who found that those nontraditional students with children under the age of thirteen experienced the most guilt. However, those that expressed their concern extended from children under the age of thirteen, but also high school aged children as well, as displayed with Debra. Although family responsibilities took participants away from campus, the family support system was crucial to their desire to stay in college. Similar to the theme of motivation, participants' commitment to being a good student and obtaining their college degree, motivated them to balance work, family, and the goal of graduating from college (Chao \& Good, 2004).

Financial concerns have been identified as a situational barrier for nontraditional students (Hardin, 2008). Although participants in this study indicated they were financially independent, all receive some form of financial aid or grants to fund their college degree; yet, none ever expressed concern about paying for college. Some participants, such as Roland and Debra, spoke in length about how the relied heavily upon the aid they received to assist them in funding activities of their daily lives (e.g., paying for car repairs). Dowd and Coury (2006a) found that community college students who take out student loans eventually realize the negative net benefits of an education that results in an associate's degree. Even more disconcerting was the fact that in Dowd and Coury's (2006b) study, only twenty percent of participant obtained their 
AA in five years, which raises the question of individuals not only failing to earn a college degree, but accumulating a troubling amount of debt.

Strong family ties and the respect of hard work were strong factors with this theme. During our discussions and data collection, each participant either talked about or took pictures of family members and their current place of employment. I felt a strong connection to this particular theme, due to my own dealings with going to school while having a family and working full-time. Their expression of how much work and family meant to them and its influence on their education goals allowed me to reflect on my own experiences and gain a deeper appreciation of the dedication one must commit to get a degree while balancing other responsibilities.

Past Educational Experiences. Excluding Kathy, each participant in this study delayed entry into college. However, Kathy only attended college for one semester before dropping out, and did not return for almost twenty years. For these types of students, returning to college can become a difficult task, and for the majority of participants in this study, not attending college earlier in life weighed heavily upon them. For example, Jennifer felt embarrassed for not taking the opportunity to attend college earlier in her life and Douglas mentioned that, although he didn't have any regrets in life, it was evident that he was excited that he finally was getting his college education.

Regarding entrance into college, Jennifer, Douglas, Debra, Jake, and Roland all delayed enrollment and Kathy is considered stop-out. Additionally, five of the six participants are firstgeneration college students. Typically, delayed enrollment is defined as an individual taking at least one year off between the transitions from high school to post-secondary education (Choy, 2002). On the other hand, a stop-out student is an individual who does not "complete their plan 
of study within the normal time schedule, having skipped a term or more and then having returned to college" (Hoyt \& Winn, 2004, p. 397). Kathy, the sole stop-out participant, attended community college for a semester before leaving to help raise a family member's child. Kathy's personal situation correlates with Barefoot's (2004) notion of a stop-out student who may need to take time off to deal with external issues.

Kathy, Douglas, Debra, Jake, and Roland are all first-generation students. As seen in Chapter 4, each one had varying degrees of educational support growing up and each had different paths that led them into college. For example, growing up, the majority of participants experienced a lack of support educationally and many reported that going to college was never highly encouraged. This lack of support was found in other studies which saw first-generation students perceiving their parents to be less supportive of education (McConnell, 2000). However, the lack of high parental education level proved not to be a hindrance upon those in this study. Taken into consideration after our interviews, it became evident to me that this background information can greatly benefit how institutions can tailor support for nontraditional students (discussed further in the proceeding implications section).

A potential cause of dropping out of college for "off-time students," is the fact that many of these individuals, during their time away from formal schooling, have developed families and obtained work commitments (Bozick \& DeLuca, 2005). For example, five out of the six delayed enrolled students in this study had family and work commitments; the sixth, Roland, was due to military service. Although Bozick and DeLuna (2005) and Hearn (1992) found that students who delayed enrollment for a year after high school were significantly likely to never obtain a degree, I found the opposite. As noted earlier, a requirement for participation in this study was 70 percent completion of a degree. In turn, I believe that a combination of the themes derived 
from our interviews provides evidence that we can narrow our research in ways to support nontraditional students.

During our interviews I found that there was unconditional support from family members in participants' pursuit of their college degree, while some studies (Terenzini, Springer, Yaeger, Pascarella, \& Nora, 1996) have reported that first-generation students receive less encouragement from home. Yet, it is evident from the photos taken during data collection that my participants felt absolute support. Kathy took pictures of her husband and children as evidence of family support. Additionally, Jennifer, Debra, and Roland each took pictures of their children, in which they all stated that their children were in full support of their educational dreams.

Age and the desire for better jobs can contribute to the support from home. For example, age can be a factor due to participants not having any known parental support, meaning if they were to receive any substantial support it would stem from their immediate family. Additionally, having more life experience as an older student can contribute to their success in college through the acquisition of skills such as organization. As opposed to a first-generation student straight out of high school who may rely heavily upon parents who have no real knowledge of the inner workings of the college environment. Furthermore, participants did report less socializing with their peers, but spoke in great length about their positive relationships with faculty, which can be attributed to the need to leave campus for work and children.

\section{Limitations}

Limitations are evident in most research, qualitative and quantitative. The study consisted of six research participants and the research took place in the college where the 
researcher worked. Since the setting was the college in which the participants attended, the results could not be generalized to the majority of nontraditional community college students.

Due to the qualitative nature of this study, all data collected was subjective and participation was voluntary and selected solely on Choy's (2002) criteria. There was an even distribution of male and female in the study. However, all participants were White. Yet, SCC currently only has one Black student over the age of 25 , which indicates that the six participants are representative of SCC's general population.

\section{Implications}

Institutional Implications. According the American Association of Community Colleges (2012) the average age of students is 28 , and it is argued that nontraditional students have now become the new traditional student; making the results from this study valuable to community college administrators regarding the experiences had by nontraditional students. Additional implications for the study of nontraditional students include the fact that an increasing number of government agencies are beginning to tie institutional funding to graduation rateswhich can be problematic for institutions that enroll large numbers of at-risk students or have a high rate of student transfer, such as nontraditional students and community colleges (Barefoot, 2004).

Campuses strive for excellence in terms of institutional prestige, qualified faculty, and resources available to students. However, these factors have come under scrutiny in terms of their validity in a quality education (Kuh, 2001). In the "traditional" campus environment just mentioned, there is little or no discussion of how students are engaging with their environment, both on and off campus. Likewise, it is not uncommon for faculty and staff to be solely concerned with their teaching responsibilities, and depending on what type of college you teach 
in, research. However, it has been shown in this study that college leaders must understand, not only the individual, but also the collective experiences of nontraditional student population as they attend college. The themes from this study should be used as a resource to increase awareness among senior administration, faculty, and staff within the college community about ways to better serve adult students.

Dispositional barriers refer to the student's concept of self and low self- concept may hamper participation (Gibson \& Graff, 1992). Participants in this study frequently spoke of their motivation, determination to graduate, and ways in which they found time to work in their studies. Yet, there were instances where they spoke of their lack of certain skills, such as studying and learning styles. Additionally, each participant talked about how the balance of his or her responsibilities has been a very stressful process.

Institutions should not assume that entering nontraditional students have the capability to understand the major balance of school, work, and family. One example I found particularly interesting was the fact the when he initially came to college, Roland did not know how to navigate a computer. His instructor was bewildered and, at first, did not believe him. This example provides the impetus for institutions need to make available the opportunity for students to receive help in the area of study and learning skills. Debra, Jake, and Roland each spoke of being underprepared upon entering college and consequently were placed into developmental courses. Additionally, they mentioned not having appropriate study skills to match the rigor at the college level. In turn, orientation sessions that are specifically designed for nontraditional students should include information about the new challenge of going to college, as well as opportunities to receive help academically. 
An additional suggestion is a summer bridge program for nontraditional students. This would be more intensive than a one day orientation, which may not provided significant time to get all necessary information across. The bridge would allow students the opportunity to explore the campus, get general information about the time, effort, and expectations required in college, and an opportunity to take refresher courses in subjects such as math and reading.

However, orientation should only be the first step. Follow-up informational flyers and emails should be sent to these students as a reminder of the opportunities available to them. A constant flow of information is necessary for this group of students due to the additional responsibilities they balance and certain information may be lost in their daily lives. I recommend this frequent follow up from my experiences during our interviews. Blocking off one to two hours to be interviewed was a struggle for some participants and I sent constant reminders about our upcoming meetings.

Orientation programs can also benefit first-generation students who typically have a difficult time navigating the college system, need additional support academically, and usually do not get support from family members who have never attended college. This further supports the idea previously mentioned in the constructivist lens section, which stated that institutions should invest in the opportunity to include family members into an orientation program and other on campus related activities.

Support academically and emotionally (validation) from faculty, staff, and family have been shown to help students in this study and in other studies as well (Rendón, 2002). Although they are older and have more life experience, nontraditional students seek more guidance and support to help navigate the college system and with higher education seen by some as a service based organization, I suggest that institutions consider investing in services and/or workshops 
relating to validation. Through validation, faculty, staff and even administrators can become part of the student's support system.

Many of the experiences that were discussed during the interviews centered on themes outside the classroom and the institutional walls. As we have seen participants valued the time faculty and staff gave them outside the classroom. Institutions can create a mentor program between nontraditional students with faculty and/or staff mentors. Informally, the helpful faculty and staff we learned about in the interviews were mentors; demonstrating the argument that a formalized faculty/staff-student relationship would be beneficial. Although we can date the relationship between faculty and student back to Pascarella (1980), it should be recognized that the student population has changed significantly since that time and community colleges are much more prevalent today. Having a mentor system or informal group meetings among faculty, staff, and nontraditional students can break down the formality of the classroom and help bridge the gap between the experience of the nontraditional student and the potentially foreign campus environment.

A final suggestion with regards to validation is to recognize the success and efforts of nontraditional students. A common honor society for community college students is Phi Theta Kappa. However, Alpha Sigma Lambda is an honor society specifically aimed at adults who keep high academic standards while balancing interests at home and work. This type of recognition can support the sense of accomplishment that many participants expressed as a motivating factor for achieving their goals.

The link between institutional commitment and student persistence plays an important role in the enrollment management and resource allocation agenda for all institutions. Furthermore, student commitment serves as a valuable planning tool because it predicts future 
persistence behavior. Considered a situational barrier, institutions should contemplate providing more opportunities and services geared toward nontraditional students on campus, such as childcare and employment opportunities. Giving campus employment opportunities to Kathy, Debra, Roland, and Jake, and future nontraditional students, would eliminate their need to rush off campus and potentially miss out on valuable academic and social opportunities. An institution's ability to provide such services can help students with the financial strain of finding childcare and eliminate some of the stress of having to leave campus to go to their place of employment.

Institutional barriers, with regards to this study, focus on the time of class offerings. Although SCC is situated in a small rural community, which causes a relatively low enrollment, the institution can invest in addressing class times that are convenient and flexible for nontraditional students. Additional alternatives include offering more independent studies. Yet, heavily independent oriented courses, such as online formats, proved difficult for participants in this study. Individuals expressed their troubles with online classes due to their unfamiliarity with the mode of delivery and lack of time. This is supported by Willging and Johnson (2004) who found that external factors such as family and work were the main reasons for dropping out of online classes. Instead, institutions should consider promoting hybrid courses to their nontraditional students. This combination of independent work and classroom interaction proved to be beneficial to Kathy and Jennifer who needed the flexibility without sacrificing the need for faculty connection.

I found that classroom time and making efforts to speak with certain faculty and staff were some of the only significant interaction students had on campus. In turn, a redesign of the curricula should be considered. For example, as mentioned in the previous paragraph, more 
independent, self-directed assignments would allow adult students to be self-starters when not on campus or in the classroom. However, as seen in this study, students would still require face-toface interaction with their faculty. Specific guidelines would be required from faculty, in which they would identify measurable objectives, assist with the location of necessary academic resources, and specify the end goals and evaluation (Moore, 1980). This type of direct outline is necessary by the faculty member, because the typical nontraditional student, although motivated, still needs guidance and support from willing instructors. Furthermore, faculty would have to be willing, when necessary, to provide time to meet face-to-face to be sure learning objectives are being met.

Methodological Implications. I have argued that institutions need to take a different approach to better understanding their student population. Phenomenology permits individuals the opportunity to present data in a new way that others may see as commonplace. The use of quantitative means to capture student experiences, such as the National Survey of Student Engagement (NSSE) or the Community College Survey of Student Engagement (CCSSE), although easily administered, lack the ability to capture the essence of the phenomena. In-depth qualitative research such as phenomenology or narrative inquiry, require a significant amount of time and the ability to use these methodologies may be impractical on a large scale that many college and universities require. However, employing open-ended questions to surveys could lead institutions to a deeper appreciation of the student experience.

Constructivism in College. Constructivism maintains that it is a "process of constructing meaning: it is how people make sense of their experience" (Merriam \& Caffarella, 1999, p. 261). Within social constructivism, meaning is derived from the interaction with various agents (e.g., family, faculty, and staff). It looks at the "unique experience of each of us; 
it suggests that each one's way of making sense of the world is as valid and worthy of respect as any other" (Crotty, 1998, p. 58). This interaction can take place in the classroom, in an advising session, discussing financial aid, or talking with one's family. The construction of the college experience is evident in the photographs taken by Kathy, Jennifer, Douglas, Debra, Jake, and Roland. The photographs provided me the chance to see how individuals view their time at SCC, which does not typically occur for faculty or administrators. The opportunity to view the experience through their eyes gave me a vantage point in which I could accurately see the interactions that occur in their lives.

Taking the themes derived from participants, this study argues, from a social constructivist lens, that participants can construct their experience through human activity and interpersonal connections. While on campus, participants spent time interacting with the campus community and building upon necessary connections. For example, Jake and Roland constructed relationships with the financial aid staff and Jennifer received encouragement to finish degree from outstanding faculty. Off campus, we have seen that interactions with family and job responsibilities impacted their overall college experience. Through these interactions, individuals built relationships and connections that helped them construct their time in college. Just as students are influenced by their interpersonal connections with others, so to, should leaders take a social constructivist approach to decision making. Community college leadership needs to take a holistic approach to understanding and supporting nontraditional students. Decisions are not made in a "social vacuum...a decision is always made in interaction with at least one other individual" (Cottone, 2001, p. 40). Informed decision-making needs to be based of the interaction of various agents, including the feedback from nontraditional students. 
Information gathered through our interviews and photographs demonstrates the importance of relationships constructed on and off campus. College leaders can learn from these relationships and better support students through the concept of mattering. Mattering is a form of external validation of individuals by others, both at the interpersonal level and the societal level (Rosenberg \& McCullough, 1981). In line with social constructivism, the interpersonal form of mattering refers to the interactions with agents such as spouses, professors, and peers. Furthermore, Schlossberg, Lynch, and Chickering (1989) postulated that:

Institutions that focus on mattering and greater student involvement will be more successful in creating campuses where students are motivated to learn, where their retention is high, and ultimately, where their institutional loyalty for the short-and long-term future is ensured. (p. 14)

The knowledge gained from direct, personal input that students provide can help college leaders discover perceptions of how well an institution is meeting the needs of their campus population. I found that motivation, helpful faculty and staff, external responsibilities, and past educational experiences all played a role in the construction of the educational experience. In relation to social constructivism, these four themes can assist in the creation of supportive institutional programs. For example, consideration should be taken to integrate specific ideas into orientation programs on how family can be involved in the student's education. Given the nature of mattering and institutional commitment, institutions can implement training for faculty, counselors and other staff on how to interact with these students and the level of support they can provide. Additionally, the notion of creating a supportive, welcoming college environment where students feel valued and important should be emphasized. 
Similar to an ecology model (Bronfenbrenner, 1977), social constructivism's goal is to demonstrate that there are many agents that influence an individual's life. College leadership can embrace constructivism implications by realizing that rich information can be garnered from a collective production of meaning among students. Likewise, administrator adaptation of constructivist leadership styles can open up new possibilities with teamwork and provide insights that may never had been available.

\section{Suggestions for Future Research}

It is important for continued research to focus on the distinct ways that nontraditional students engage and integrate in the college experience. The following are a list of recommendations based of the results of this study.

1. Using the same methodology and data collection (photographs), this study needs to be repeated in other community colleges. Although Choy's (2002) criteria can be used to recruit participants, additional student categories should be considered, such as minorities and veterans.

2. Many colleges continue to assess the needs of students based off traditional standards. However, as argued before in this study, the characteristics of a traditional and a nontraditional student are become blurred, especially in the community college setting. Further study on current differences and likenesses between traditional and nontraditional would add to the existing literature.

3. Validation from faculty and staff was a fundamental experience for each participant in the study. Further research on how validation helps nontraditional students in community college would reveal a deeper understanding of their persistence. 
4. Institutional commitment did not occur with participants in this study. Individual external responsibilities frequently took participants off campus. Further study should be conducted with regards to creation of clubs, communal organizations, and family services geared toward nontraditional students and its impact on retention.

5. There is a misperception that still exists that adult learners are self-supporting and do not need the same level of support as traditional age students. In reality, this study showed adult students need just as much, if not more, support with navigating the college system. Additional research should be conducted regarding the level of support provided by an institution to help adult students persist to graduation. For example, can an orientation program assist in helping nontraditional students persist.

\section{Summary}

Although administrators at community colleges recognize the importance that adult students bring to their institutions, overall, these same administrators have issues to address in regards to better understanding this student population. I have provided the insights that emerged from the data collected from six participants. The insights revolve around participant characteristics and the various practices an institution can adopt to better support nontraditional students. The stories that unfolded in this research project painted a picture of a group of individuals who were determined to graduate, juggled many responsibilities, valued caring faculty and staff, and had similar past experiences. Therefore, the college experience, and the motivation to graduate, is a journey that encapsulated hard work and campus and family support.

Similarly to Bronfenbrenner's (1977) ecology model, institutions must realize that for nontraditional students, there are various levels of influences that weigh on their college experiences. College leaders who choose to take these suggestions into consideration should 
realize that results are not always immediate. According to Tinto, (2012) on average, it will take three to four years for a new program to become successful. During implementation of new programs the appropriate faculty and staff need to build curriculum and become trained.

Although nontraditional student traits are primarily used as benchmarks to define risks associated with this population, it has been shown in the previous paragraphs that the themes that emerged from the study can be of beneficial use to administrators for planning appropriate programs and support structures. These various themes have the potential to add to the national dialogue regarding community colleges and nontraditional students and to help lead to new dialogue.

\section{Conclusion: Thoughts on this Experience}

Through this study, I set out to learn more about the educational experiences of nontraditional students. I believe this study will lend itself to the existing research by exploring what college it like for these students and the variable that play a role in their experiences toward graduation.

It was my intention when starting this study for both the researcher and participant to gain a deeper understanding of the educational experience. In order to do this, I had to step outside my comfort zone on multiple occasions when participants let me into their lives to learn more about their past. Yet, those uncomfortable situations have allowed me to see a side of students that is not normally found in a survey, or even generally known. Through this study, I have gained a deeper appreciation of the variables that play a role in students' lives. Faculty and administrators alike should consider the factors described in the previous sections to help themselves professionally. We traditionally see our students as just that, students, yet we may want to consider and appreciate what is going on outside our classroom walls. This is especially 
true for nontraditional students; who, along with their studies, are typically parents, husband/wife, and employees.

This study has had a profound effect on the way I view my own educational experience and the opportunities I was given. During our interviews and while writing the findings, I felt a connection to these individuals. Likewise, they expressed their gratitude on having the chance to reflect on their own life and experiences. The goal of this study was not generalization, but to increase understanding, providing the opportunity for readers to build upon their own knowledge. I hope, in the end, I have provided a sufficient amount of data and interpretations to allow the reader to determine its applicability. 


\section{References}

Abdal-Haqq, I. (1998). Constructivism in teacher education: Considerations for those who would theory to practice. ERIC Digest Identifier ED426986. Retrieved from http://www.ericdigests.org/1999-3/theory.htm

Adelman, C., \& Prosser, J. (1998). Photocontext. In Image-based research: A sourcebook for qualitative researchers (pp. 148-161). Bristol, PA: Falmer Press.

American Association of Community Colleges. (2012a). Community college fast facts.

Washington, DC: American Association of Community Colleges. Retrieved from http://www.aacc.nche.edu/AboutCC/Documents/FactSheet2012.pdf

American Association of Community Colleges. (2012b). Reclaiming the American dream: A report from the 21st-century commission on the future of community colleges.

Washington, DC. Retrieved from http://www.aacc.nche.edu/21stCenturyReport

American Association of Community Colleges. (2013). 2013 Community college fast facts.

Washington, DC. Retrieved from

http://www.aacc.nche.edu/AboutCC/Documents/2013facts_fold_revised.pdf

Apps, J. W. (1981). The adult learner on campus: A guide for instructors and administrators.

Chicago, IL: Follett.

Astin, A. W. (1985). Achieving educational excellence. San Francisco, CA: Jossey-Bass.

Astin, A. W. (1993). What matters in college? Four critical years revisited. San Francisco, CA: Jossey-Bass.

Aud, S., Hussar, W., Johnson, F., Kena, G., Roth, E., Manning, E., \& Zhang, J. (2012). The condition of education 2012 (NCES 2012-045). Washington, DC: U.S. Department of 
Education. Institute of Education Sciences, National Center for Educational Statistics. Retrieved from http://nces.ed.gov/pubs2012/2012045.pdf

Aud, S., Hussar, W., Kena, G., Bianco, K., Frohlich, L., Kemp, J., \& Tahan, K. (2011). The condition of education 2011 (NCES 2011-033). Washington, DC: U.S. Department of Education. Institute of Education Sciences, National Center for Education Statistics. Retrieved from http://nces.ed.gov/pubs2011/2011033.pdf

Bailey, T., Calcagno, J. C., Jenkins, D., Leinbach, T., \& Kienzl, G. (2006). Is student right to know all you should know? An analysis of community college graduation rates. Research in Higher Education, 47(5), 491-519.

Bailey, T. R., \& Alfonso, M. (2005). Paths to persistence: An analysis of research on program effectiveness at community colleges. Indianapolis, IN: Lumina Foundation for Education. Retrieved from http://www.luminafoundation.org/publications/PathstoPersistence.pdf

Baker, T. L. (1994). Doing social research (2nd ed.). New York, NY: McGraw-Hill.

Barefoot, B. O. (2004). Higher education's revolving door: confronting the problem of student drop out in us colleges and universities. Open Learning, 19(1), 9-18.

Barkway, P. (2001). Michael Crotty and nursing phenomenology: Criticism or critique? Nursing Inquiry, 8(3), 191-195.

Barnett, E. A. (2011). Validation experiences and persistence among community college students. The Review of Higher Education, 34(2), 193-230.

Bauman, S. S. M., Wang, N., DeLeon, C. W., Kafentzis, J., Zavala-Lopez, M., \& Lindsey, M. S. (2004). Nontraditional students' service needs and social support resources: A pilot study. Journal of College Counseling, 7(1), 13-17. 
Beach, J. M. (2011). Gateway to opportunity? A history of the community college in the United States. Sterling, VA: Stylus Publishing.

Bean, J. P., \& Metzner, B. S. (1985). A conceptual model of nontraditional undergraduate student attrition. Review of Educational Research, 55, 485-540.

Beech, I. (1999). Bracketing in phenomenological research. Nurse Researcher, 6, 35-51.

Beilin, R. (2005). Photo-elicitation and the agricultural landscape: "Seeing" and "telling" about farming, community and place. Visual Studies, 20(1), 56-68.

Berger, J. B., \& Lyon, S. C. (2005). Past to present: A historical look at retention. In A. Seidman (Ed.), College student retention: Formula for student success (pp. 1-30). Westport, CT: American Council on Education/Praeger.

Blinn, L., \& Harrist, A. W. (1991). Combining native instant photography and photo-elicitation. Visual Anthropology, 4(2), 175-192.

Bloustein, G., \& Baker, S. (2003). On not talking to strangers; researching the micro worlds through visual auto ethnographic schools. Social Analysis, 47(3), 64-79.

Bolman, L. G., \& Gallos, J. V. (2011). Reframing academic leadership. San Francisco, CA: Jossey-Bass.

Bowl, M. (2001). Experiencing the barriers: Non-traditional students entering higher education. Research Papers in Education, 16(2), 141-160.

Bozick, R., \& DeLuca, S. (2005). Better late than never? Delayed enrollment in the high school to college transition. Social Forces, 84(1), 531-554.

Bragg, D. D. (2001). Community college access, mission, and outcomes: Considering intriguing intersections and challenges. Peabody Journal of Education, 76, 93-116. 
Braxton, J. M., Hirschy, A. S., \& McClendon, S. A. (2004). Understanding and reducing college student departure (Vol. 30). San Francisco, CA: Jossey-Bass.

Braxton, J. M., Sullivan, A. S., \& Johnson, R. (1997). Appraising Tinto's theory of college student departure. In J. Smart (Ed.), Higher Education Handbook of Theory and Research (Vol. 12, pp. 107-164). New York: Agathon.

Bronfenbrenner, U. (1977). Toward an experimental ecology of human development. American Psychologist, 32(7), 513-531.

Brown, S. M. (2002). Strategies that contribute to nontraditional/adult student development and persistence. PAACE Journal of Lifelong Learning, 11, 67-76.

Campos-Monteiro, J., \& Dollinger, S. J. (1998). An autographic study of poverty, collective orientation, and identity among street children. The Journal of Social Psychology, 138(3), 403-406.

Carnevale, A. P., Smith, N., \& Strohl, J. (2010). Help wanted: Projections of jobs and education requirements through 2018. Washington, D.C.: Georgetown University Center on Education and the Workforce. Retrieved from http://cew.georgetown.edu/jobs2018/

Chao, R., \& Good, G. E. (2004). Nontraditional students' perspectives on college education: A qualitative study. Journal of College Counseling, 7(1), 5-12.

Choy, S. (2002). Nontraditional undergraduates: Findings from the condition of education 2002 (No. NCES 2002-012). U.S. Department of Education, National Center for Educational Statistics. Retrieved from http://nces.ed.gov/pubsearch/pubsinfo.asp?pubid=2002012 Clark-Ibanez, M. (2004). Framing the social world with photo-elicitation interviews. The American Behavioral Scientist, 47(12), 1507-1526. 
Cohen, A. M. (1990). The case for the community college. American Journal of Education, 98, 426-442.

Cohen, A. M., \& Brawer, F. B. (2008). The American community college. San Francisco, CA: Jossey-Bass.

Collier, J. (1957). Photography in anthropology: A report on two experiments. American Anthropologist, 59(5), 843-859.

Creswell, J. (2013). Qualitative inquiry and research design: Choosing among five approaches (3rd ed.). Thousand Oaks, CA: Sage Publications.

Cross, K. P. (1981). Adults as learners: Increasing participation and facilitating learning. San Francisco, CA: Jossey-Bass.

Crotty, M. (1998). The foundations of social research: Meaning and perspectives in the research process. London: Sage.

Damisch, H. (1978). Five notes for a phenomenology of the photographic image. October, 5, 7072.

Decrop, A. (1999). Triangulation in qualitative tourism research. Tourism Management, 20(1), 157-161. doi:10.1016/S0261-5177(98)00102-2

Denscombe, M. (2003). The good research guide. Berkshire, UK: Open University Press.

Diamond, R. M. (2008). Designing and assessing courses and curricula: A practical guide (3rd ed.). San Francisco, CA: Jossey-Bass.

Dowd, A., \& Coury, T. (2006). The effect of loans on the persistence and attainment of community college students. Research in Higher Education, 47(1), 33-62.

Ely, E. E. (1997). The non-traditional student (p. ERIC Document Reproduction Service No. ED411906). Retrieved from 
http://www.eric.ed.gov/ERICWebPortal/contentdelivery/servlet/ERICServlet?accno=ED 411906

Fairchild, E. E. (2003). Multiple roles of adult learners. New Directions for Student Services, (102), 11-16.

Fike, D. S., \& Fike, R. (2008). Predictors of first-year student retention in the community college. Community College Review, 36(2), 68-88. doi:10.1177/0091552108320222

Foote, E. (1998). Sources and information on organizational change in the community college. In Organizational change in the community college: A ripple or sea change? (Vol. 102, pp. 99-106). San Francisco, CA: Jossey-Bass.

Gibson, C. C., \& Graff, A. O. (1992). Impact of adults' preferred learning styles and perception of barriers on completion of external baccalaureate degree programs. Journal of Distance Education, 7(1), 39-51.

Habley, W. R., \& McClanahan, R. (2004). What works in student retention? Two year public colleges. Iowa City, IA: ACT.

Hardin, C. J. (2008). Adult students in higher education: A portrait of transition. New Directions for Higher Education, 144, 49-57.

Harper, D. (1984). Meaning and work: A study in photo elicitation. International Journal of Visual Sociology, 2(1), 20-43.

Harper, D. (1988). Visual sociology: Expanding sociological vision. The American Sociologist, 19(1), 54-70.

Harper, D. (1998). An argument for visual sociology. In Jon Prosser (Ed.), Image-based research: A sourcebook for qualitative researchers (pp. 24-41). Bristol, PA: Falmer Press. 
Harper, D. (2000). Reimagining visual methods: Galileo to neuromancer. In N. Denzin \& Y. Lincoln (Eds.), Handbook of Qualitative Research (2nd ed., pp. 717-732). Newbury Park, CA: Sage.

Harper, D. A. (2012). Visual sociology. New York, NY: Routledge.

Harrington, C. E., \& Schibik, T. J. (2003). Reflexive photography as an alternative method for the study of the freshman year experience. NASPA Journal, 41, 23-40.

Hatch, J. A. (2002). Doing qualitative research in education settings. Albany, NY: State University of New York.

Hearn, J. C. (1992). Emerging variations in postsecondary attendance patterns: An investigation of part-time, delayed, and nondegree enrollment. Research in Higher Education, 33(6), 657-687.

Hermanowicz, J. C. (2006). Reasons and reasoning for leaving college among the academic elite: Case study findings and implications. Journal of College Student Retention: Research, Theory and Practice, 8(1), 21-38.

Hill, R. (2005). Social constructivism. In L. M. English (Ed.), International encyclopedia of adult education. New York: Palgrave MacMillian.

Hoyt, J. E., \& Winn, B. A. (2004). Understanding retention and college student bodies: Differences between drop-outs, stop-outs, opt-outs, and transfer-outs. NASPA Journal (National Association of Student Personnel Administrators, Inc.), 41(3), 395-417.

Husserl, E. (1982). Ideas pertaining to a pure phenomenology and to a phenomenological philosophy. (F. Kersten, Trans.). Hingham, MA: Kluwer Boston.

Husserl, E. (1990). The idea of phenomenology. (W. P. Alston \& G. Nakhnikian, Trans.). Dordrecht, The Netherlands: Kluwer Academic. 
Husserl, E. (2001). Logical investigations. (Dermot Moran, Ed.) (2nd ed.). London: Routledge.

Jones, S. R., Torres, V., \& Arminio, T. (2006). Negotiating the complexities of qualitative research in higher education: Fundamental elements \& issues. New York, NY: Routledge.

Josselson, R. (2013). Interviewing for qualitative inquiry: A relational approach. New York, NY: Guilford Press.

Kane, T. J., \& Rouse, C. E. (1999). The community college: Educating students at the margin between college and work. The Journal of Economic Perspectives, 13, 63-84.

Kasworm, C. E., Polson, C. J., \& Fishback, S. J. (2002). Responding to adult learners in higher education. Malabar, FL: Krieger Publishing Company.

Kelly, A. P., \& Schneider, M. (2012). Introduction. In A. P. Kelly \& M. Schneider (Eds.), Getting to graduation: The completion agenda in higher education (pp. 1-13). Baltimore, MD: The Johns Hopkins University Press.

Kerka, S. (2005). Research methods. In L. M. English (Ed.), International encyclopedia of adult education (pp. 554-560). New York, NY: Palgrave MacMillian.

Kim, K. A. (2002). ERIC review: Exploring the meaning of "nontraditional" at the community college. Community College Review, 30(74), 74-89.

Knowles, M. S., Holton, E. F., \& Swanson, R. A. (2011). The adult learner: The definitive classic in adult education and human resource development (7th ed.). Burlington, MA: Elsevier.

Kuh, G. D. (2001). Assessing what really matters to student learning: Inside the national survey of student engagement. Change, 33(3), 10-17. 
Kuh, G. D., Kinzie, J., Buckley, J. A., Bridges, B. K., \& Hayek, J. C. (2006). What matters to student success: A review of the literature. National Postsecondary Education Cooperative. Retrieved from http://nces.ed.gov/npec/pdf/kuh_team_report.pdf

Laanan, F. S. (2000). Community college students' career and educational goals. New Directions for Community Colleges, 112, 19-33.

Laing, C., Kuo-Ming, C., \& Robinson, A. (2005). Managing the expectations of nontraditional students: A process of negotiation. Journal of Further \& Higher Education, 29(2), 169179.

Lake, R. (Ed.). (2010). Dear Maxine: Letters from the unfinished conversation with Maxine Greene. New York, NY: Teachers College Press.

Levin, J. S. (1998). Organizational change and the community college. In J. S. Levin (Ed.), Organizational change in the community college: A ripple or sea change? (Vol. 102, pp. 1-4). San Francisco, CA: Jossey-Bass.

Levin, J. S. (2003). Students beyond the margin. Presented at the Association for the Study of Higher Education, Portland, OR.

Levin, J. S. (2007). Nontraditional students and community college: The conflict of justice and neoliberalism. New York, NY: Palgrave MacMillian.

Levin, J. S., \& Montero-Hernandez, V. (2009). Community college and their students: Coconstruction and organizational identity. New York, NY: Palgrave MacMillian.

Levine, A., \& Nidiffer, J. (1996). Beating the odds: How the poor get to college. San Francisco, CA: Jossey-Bass.

Lincoln, Y. S., \& Guba, E. G. (1985). Naturalistic inquiry. Beverly Hills, CA: Sage. 
Loeffler, T. A. (2004). A photo elicitation study of the meaning of outdoor adventure experiences. Journal of Leisure Research, 36(4), 536-556.

Lumina Foundation for Education. (2012). A stronger nation through higher education: How and why Americans must achieve a big goal for college attainment. Indianapolis, IN. Retrieved from http://www.luminafoundation.org/state_work.html

Luzzo, D. A. (1999). Identifying the career decision-making needs of nontraditional college students. Journal of Counseling \& Development, 77(2), 135-140.

Mapp, T. (2008). Understanding phenomenology: The lived experience. British Journal of Midwifery, 16(5), 308-311.

McConnell, P. J. (2000). ERIC review: What community colleges should do to assist firstgeneration students. Community College Review, 28(3), 75-87.

doi: $10.1177 / 009155210002800305$

McGivney, V. (2004). Understanding persistence in adult learning. Open Learning, 19(1), 3346.

McNeely, J. H. (1937). College student mortality (No. 11). Washington, DC: U.S. Government Printing Office: U.S. Office of Education, Bulletin.

Merriam, S. B., \& Caffarella, R. S. (1999). Learning in adulthood: A comprehensive guide (2nd ed.). San Francisco, CA: Jossey-Bass.

Metzner, B. S., \& Bean, J. P. (1987). The estimation of a conceptual model of nontraditional undergraduate student attrition. Research in Higher Education, 27, 15-38.

Miles, M. B., \& Huberman, A. M. (1994). Qualitative data analysis (2nd ed.). Thousand Oaks, CA: Sage Publications. 
Miller, J., \& Glassner, B. (2004). The "inside" and the "outside". Finding realities in interviews. In D. Silverman (Ed.), Qualitative research: Theory, method and practice (2nd ed., pp. 126-139). London: Sage.

Moerer-Urdahl, T., \& Creswell, J. W. (2004). Using transcendental phenomenology to explore the "ripple effect" in a leadership mentoring program. International Journal of Qualitative Methods, 3(2), 19-35.

Moore, M. G. (1980). Independent study. In R. D. Boyd \& J. W. Apps (Eds.), Redefining the discipline of adult education (pp. 16-31). San Francisco, CA: Jossey-Bass.

Moustakas, C. (1994). Phenomenological research methods. Thousand Oaks, CA: Sage.

Munhall, P. L. (1994). Revisioning phenomenology: Nursing and health science research. New York, NY: National League for Nursing Press.

National Center for Higher Education Management Systems - Information Center for Higher Education Policymaking and Analysis. (2009). Progress and completion: Graduation rates. Retrieved from http://www.higheredinfo.org/dbrowser/index.php?measure=19

Nevarez, C., \& Wood, J. L. (2010). Community college leadership and administration: Theory, practice and change. New York, NY: Peter Lang Publishing.

NVivo qualitative data analysis software (Version 10). (2012). Burlington, MA: QSR International.

Ogren, C. A. (2003). Rethinking the "nontraditional" student from a historical perspective: State normal schools in the late nineteenth and early twentieth centuries. The Journal of Higher Education, 74(6), 640-664. 
Oldfather, P., West, J., \& White, J. (1999). Learning through children's eyes: Social constructivism and the desire to learn. Washington, DC: American Psychological Association.

Pascarella, E. T. (1980). Student-faculty informal contact and college outcomes. Review of Educational Research, 50(4), 545-595.

Pascarella, E. T., \& Terenzini, P. T. (1980). Predicting freshman persistence and voluntary dropout decisions from a theoretical model. The Journal of Higher Education, 51, 60-75.

Pascarella, E. T., \& Terenzini, P. T. (1998). Studying college students in the 21 st century: Meeting new challenges. The Review of Higher Education, 21(2), 151-165.

Patton, M. Q. (2002). Qualitative research and evaluation methods (3rd ed.). Thousand Oaks, CA: Sage.

Pettersson, M. (2011). Depictive traces: On the phenomenology of photography. Journal of Aesthetics \& Art Criticism, 69(2), 185-196.

Polkinghorne, D. E. (1989). Phenomenological research methods. In R. S. Valle \& S. Halling (Eds.), Existential-phenomenological perspectives in psychology: Exploring the breadth of human experience (pp. 41-60). New York, NY: Plenum Press.

Price, K., \& Baker, S. N. (2012). Measuring students' engagement on college campuses: Is the NSSE an appropriate measure of adult students' engagement? Journal of Continuing Higher Education, 60(1), 20-32.

Prosser, J. (1998). The status of image-based research. In Jon Prosser (Ed.), Image-based research: A sourcebook for qualitative researchers (pp. 97-112). Bristol, PA: Falmer Press. 
Provasnik, S., \& Planty, M. (2008). Community college: Special supplement to the condition of education 2008 (NCES 2008-033). Washington, DC: U.S. Department of Education. Institute of Education Sciences, National Center for Education Statistics. Retrieved from http://nces.ed.gov/pubs2008/2008033.pdf

Prus, R. (1990). The interpretive challenge: The impending crisis in sociology. The Canadian Journal of Sociology, 15(3), 355-363.

Pusser, B., Breneman, D. W., Gansneder, B. M., Kohl, K. J., Levin, J. S., Milam, J. H., \& Turner, S. E. (2007). Returning to learning: Adults' success in college is key to America's future. Indianapolis, IN: Lumina Foundation for Education. Retrieved from http://www.luminafoundation.org/publications/researchreports.html

Putnam, L. L. (1982). Paradigms for organizational communication research: An overview and synthesis. Western Journal of Speech Communication, 46(2), 192-206.

Radford, A. W., Berkner, L., Wheeless, S. C., \& Shepherd, B. (2010). Persistence and attainment of beginning postsecondary students: After 6 years (No. NCES 2011-151). Washington, DC: U.S. Department of Education, National Center for Educational Statistics. Retrieved from http://nces.ed.gov/pubsearch

Rendón, L. I. (1994). Validating culturally diverse students: Toward a new model of learning and student development. Innovative Higher Education, 19(1), 33-50.

Rendón, L. I. (1995). Facilitating retention and transfer for first generation students in community college. ERIC Document Reproduction Service No. ED383369 presented at the New Mexico Institute, Rural Community College Inititative, Espanola, NM.

Rendón, L. I. (2002). Community college puente: A validating model of education. Educational Policy, 16(4), 642-667. 
Rendón, L. I., \& Jalomo, R. (1995). Validating student experiences and promoting progress, performance, and persistence through assessment. Presented at the NCTLA Assessment Institute, Los Angeles, CA.

Rendón, L. I., Jalomo, R. E., \& Nora, A. (2000). Theoretical considerations in the study of minority retention. In J. M. Braxton (Ed.), Reworking the Student Departure Puzzle (pp. 127-156). Nashville, TN: Vanderbilt University Press.

Richardson, J. T. E., \& King, E. (1998). Adult students in higher education: Burden or boon? The Journal of Higher Education, 69, 65-88.

Rosenberg, M., \& McCullough, B. C. (1981). Mattering: Inferred significance and mental health among adolescents. Research in Community \& Mental Health, 2, 163-182.

Roueche, J. E., \& Hurlburt, A. S. (1968). The open-door college: The problem of the low achiever. The Journal of Higher Education, 39, 453-456.

Rovai, A. P. (2003). In search of higher persistence rates in distance education online programs. The Internet and Higher Education, 6(1), 1-16. doi:10.1016/S1096-7516(02)00158-6

Saldaña, J. (2012). The coding manual for qualitative researchers (2nd ed.). Thousand Oaks, CA: Sage.

Schlossberg, N. K., Lynch, A. Q., \& Chickering, A. W. (1989). Improving higher education for adults: Responsive programs and services from entry to departure. San Francisco, CA: Jossey-Bass.

Schreiner, L. A., Noel, P., Anderson, E., \& Cantwell, L. (2011). The impact of faculty and staff on high-risk college student persistence. Journal of College Student Development, 52(3), 321-338. doi:10.1353/csd.2011.0044 
Schumacher, S., \& McMillian, J. (1993). Research in education: A conceptual introduction (3rd ed.). New York, NY: Harper Collins.

Schunk, D. H. (2000). Learning theories. Upper Saddle River, NJ: Prentice-Hall.

Scott, L. M., \& Lewis, C. W. (2011). Nontraditional college students: Assumptions, perceptions, and directions for a meaningful academic experience. International Journal of Interdisciplinary Social Sciences, 6(4), 1-10.

Seidman, I. (2013). Interviewing as qualitative research: A guide for researchers in education \& the social sciences (4th ed.). New York, NY: Teachers College Press.

Simon, M. K. (2011). Dissertation and scholarly research: Recipes for success. Seattle, WA: Dissertation Success, LLC.

Sinkovics, R. R., \& Alfoldi, E. A. (2012). Progressive focusing and trustworthiness in qualitative research. Management International Review, 52(6), 817-845. doi:10.1007/s11575-0120140-5

Sissel, P. A., Hansman, C. A., \& Kasworm, C. E. (2001). The politics of neglect: Adult learners in higher education. New Directions for Adult and Continuing Education, 91, 17-27.

Slotnick, H. B., Pelton, M. H., Fuller, M. L., \& Tabor, L. (1993). Adult learners on campus. Bristol, PA: Falmer Press.

Smith, J. A., \& Osborn, M. (2003). Interpretive phenomenological analysis. In J. A. Smith (Ed.), Qualitative Psychology: A Practical Guide to Methods (pp. 53-79). London: Sage.

Snyder, T. D., Dillow, S. A., \& Hoffman, C. M. (2007). Digest of education statistics 2006 (NCES 2007-017). Washington, DC: U.S. Department of Education. Retrieved from http://nces.ed.gov/pubs2007/2007017.pdf 
Spady, W. G. (1970). Dropouts from higher education: An interdisciplinary review and synthesis. Interchange, 1, 64-85.

Terenzini, P. T., Springer, L., Yaeger, P. M., Pascarella, E. T., \& Nora, A. (1996). First generation college students: Characteristics, experiences, and cognitive development. Research in Higher Education, 37(1), 1-22.

Thomas, L. (2002). Student retention in higher education: The role of institutional habitus. Journal of Education Policy, 17(4), 423-442.

Tinto, V. (1993). Leaving college: Rethinking the causes and cures of student attrition. Chicago, IL: The University of Chicago Press.

Tinto, V. (2012). Completing college: Rethinking institutional action. Chicago, IL: The University of Chicago Press.

Townsend, B. K., \& Dever, J. T. (1999). What do we know about reverse transfer students? New Directions for Community Colleges, 1999(106), 5-14.

U.S. Census Bureau. (2011). American community survey: Educational attainment for the population 25 years and over. Washington, DC: U.S. Department of Commerce. Retrieved from http://factfinder2.census.gov/faces/tableservices/jsf/pages/productview.xhtml?pid=ACS 11_1YR_C15003\&prodType=table

Valadez, J. (1993). Cultural capital and its impact on the aspirations of nontraditional college students. Community College Review, 21(3), 30-43. doi:10.1177/009155219302100304

Van Manen, M. (1997). Researching lived experience: Human science for an action sensitive pedagogy (2nd ed.). Ontario, CA: The Althouse Press. 
Walker, D. (1995). Constructivist leadership: Standards, equity, and learning--weaving whole cloth from multiple strands. In L. Lambert, D. Walker, D. Zimmerman, J. Cooper, M. Lambert, M. Gardner, \& P. Slack (Eds.), The constructivist leader (pp. 1-33). New York, NY: Teachers College Press.

Wild, L., \& Ebbers, L. (2002). Rethinking student retention in community colleges. Community College Journal of Research and Practice, 26, 503-519. doi: $10.1080 / 02776770290041864$

Willging, P. A., \& Johnson, S. D. (2004). Factors that influence students' decision to drop out of online courses. Journal of Asynchronous Learning Network, 8(4), 105-118.

Witt, A. A., Wattenbarger, J. L., Gollattscheck, J. F., \& Suppiger, J. E. (1994). America's community colleges: The first century. Washington, DC: Community College Press.

Wyatt, L. G. (2011). Nontraditional student engagement: Increasing adult student success and retention. Journal of Continuing Higher Education, 59(1), 10-20.

Ziller, R. C., \& Smith, D. E. (1977). A phenomenological utilization of photographs. Journal of Phenomenological Psychology, 7(2), 172-182. 
Appendices 
Appendix A

Letter of Permission

V. WestVurginiaUniversity.

Human Research Protocol

\section{Letter of Permission to Conduct Research}

1, $=2$ give my permission for Alex Tuel to conduct his study entitled The Nontraditional Community College Student: A Phenomenological Approach to the Educational Experience at Garrett College.

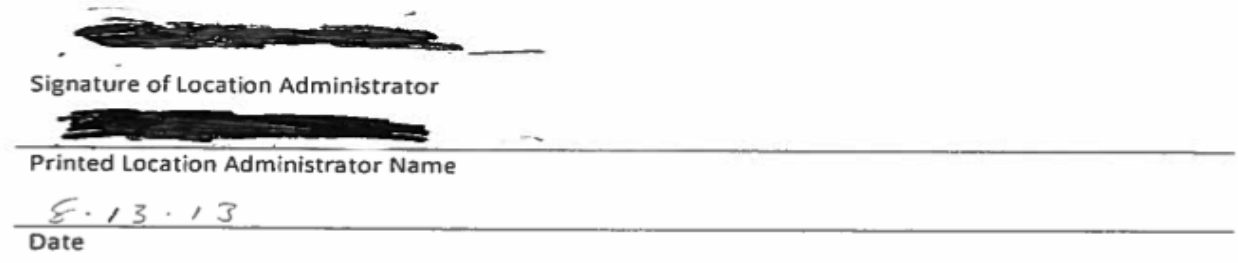




\section{Appendix B}

\section{Cover Letter to Participants}

Dear Participant,

This letter is a request for you to take part in a research project to explore the educational experiences of nontraditional students in community college. This project is being conducted by Alex Tuel with supervision of Dr. Donna Breault, for a Doctoral Degree in Curriculum and Instruction. Your participation in this project is greatly appreciated and will require three (3) one (1) hour interviews to complete. Additionally, you will be asked to take photographs that capture your experience in college.

Your involvement in this project will be kept as confidential as legally possible. All data will be reported in the aggregate. You must be 18 years of age or older to participate. I will not ask any information that should lead back to your identity as a participant. Your participation is completely voluntary. You may skip any question that you do not wish to answer and you may discontinue at any time. West Virginia University's Institutional Review Board acknowledgement of this project is on file. (1307069574)

I hope that you will participate in this research project, as it could be beneficial in understanding the educational experiences of nontraditional students in community college. Thank you very much for your time. Should you have any questions about this letter or the research project, please feel free to contact Alex Tuel at (301) 387-3028 or at alexander.tuel@garrettcollege.edu.

Thank you for your time and help with this project.

Sincerely, Alex Tuel 


\title{
Appendix C
}

\author{
Consent Information Form
}

\begin{abstract}
Principal Investigator
Department

Protocol Number

Study Title

Alex Tuel

College of Education \& Human Services: Curriculum and Instruction

Click here to enter text.

Approach to the Educational Experience
\end{abstract}

\section{Contact Persons}

You may contact Alex Tuel at (301) 387-3028 or alexander.tuel@garrettcollege.edu if you have any questions or concerns.

If you have any questions, concerns, or complaints about this research, you can also contact Dr. Donna Breault at (304) 293-3441.

For information regarding your rights as a research subject, to discuss problems, concerns, or suggestions related to the research, or to obtain information about the research, contact the Office of Research Integrity \& Compliance at (304) 293-7073.

\section{Introduction}

You have been asked to participate in this research study, which has been explained to you by Alex Tuel. This study is investigating nontraditional students educational experiences at community college.

\section{Purpose(s) of the Study}

The goal of this study is to discover how degree seeking, moderate to high nontraditional community college students experience education. For the purpose of this study educational experience will include activities that occur inside and outside of campus life (e.g., academic work, faculty, staff, students, family, work, and any other internal and external responsibilities). Additionally, how might institutions use their perspectives in conjunction with other research to modify curriculum and programming to retain this student population? The research question that will guide the collection and analysis of this research is: What is the educational experience of nontraditional students in community college?

\section{Description of Procedures}

This study involves you taking part in three (3) separate interviews and taking photographs. Each interview will take no longer than one (1) hour and the photographs will be taken over a one (1) week period. If you have children, you may take their photographs if they are present and you sign off for the use of their pictures. In total your participation will take approximately one (1) month to complete. During this study you will be asked to fill out a background information form, be interviewed on three (3) separate occasions, and take photographs regarding your educational experiences. This study is voluntary and you may leave at anytime. 


\section{Discomforts}

There are no known or expected risks from participating in this study. However, there may be minor inconveniences to time due to the interviews and photography.

\section{Benefits}

Although you will not receive any financial compensation for your participation, the knowledge gained about your educational experience may provide personal insight to your goals. Additionally, the knowledge gained from this study may eventually benefit others.

\section{Financial Considerations}

There are no special fees for participating in this study.

\section{Confidentiality}

Any information about you that is obtained as a result of your participation in this research will be kept as confidential as legally possible. Your research records and results may be subpoenaed by court order or may be inspected by the study sponsor or federal regulatory authorities (including the FDA if applicable) without your additional consent.

In addition, there are certain instances where the researcher is legally required to give information to the appropriate authorities. These would include mandatory reporting of information about behavior that is imminently dangerous to your child or to others, such as suicide, child abuse, etc.

Audiotapes and photographs will be kept locked up and will be destroyed as soon as possible after the research is finished.

In any publications that result from this research, neither your name nor any information from which you might be identified will be published without your consent.

\section{Voluntary Participation}

Participation in this study is voluntary. You are free to withdraw your consent to participate in this study at any time.

Refusal to participate or withdrawal will not affect your academics and will involve no penalty to you. Refusal to participate or withdrawal will not affect your time at Garrett College.

In the event new information becomes available that may affect your willingness to participate in this study, this information will be given to you so that you can make an informed decision about whether or not to continue your participation.

You have been given the opportunity to ask questions about the research, and you have received answers concerning areas you did not understand.

Upon signing this form, you will receive a copy.

I willingly consent to participate in this research. 


\section{Signature of Subject}

Printed Name

Date

Time

The participant has had the opportunity to have questions addressed. The participant willingly agrees to be in the study.

Signature of Investigator

Printed Name

Date

Time 


\author{
Appendix D \\ Interview Protocol: Adopted from Seidman (2013) \\ Follow Up Questions: Adopted from Josselson (2013)
}

\title{
Interview 1: Focused Life History
}

- Describe what school was like for you before college. Are there specific positive and/or negative experiences?

- Based off their description, get to the people who helped. Draw them into telling their stories and then ask questions related to the additional questions but clearly connected to what they are saying.

Additional questions:

1. What memories do you have of going school?

2. Whom do you credit with helping you while in school?

3. Where do you recall receiving the most help while in school? Home? Teachers? Other family members? Friends?

4. How do you feel about your ability to handle schoolwork?

\section{Interview 2: Details of Experience}

- What have your experiences in community college been?

Additional questions:

1. Can you please share a memorable story about your educational experience while at the community college?

- Are there specific positive and/or negative experiences? Can you please elaborate?

- Have you experienced any challenges? Can you please elaborate?

Interview 3: Reflection on the Meaning (Photographs Used During This Process)

- Please reflect upon your educational experience in college in relation to the various factors that play a role within this context (e.g., family, college administration, work) and how have these factors helped you attain your educational goals.

- The photographs taken by each participant will be looked at in the final interview. Each photograph will be accompanied by the questions: (1) what is this a picture of? (2) why did you take this picture? (3) what does this picture mean to you?

Additional questions:

- Given what you have said about your educational experience prior to community college and what you have talked about in your current experiences, how do you view education in your life?

- How do you see your experiences in college and how has it shaped your goal to attain a degree and graduate?

- Do you feel a college degree is important?

- Have you always felt a college degree was important? 


\section{Follow Up Questions}

A series of examples used when follow up questions were required (Josselson, 2013):

Clarification Questions

- Tell me about the last time this happened

- Can you tell me an example?

Empathy Questions

- What was that like from you?

- Tell me more about what you meant by that

- How did that feel to you?

- How did that come about?

- You mentioned this difficult time in your life. Can you tell me more about that?

Acknowledge Achievement

- It sounds like you are very proud of this 


\section{Appendix E}

\section{Photography and Journal Requirements}

You will be asked to take a minimum of fifteen (15) photographs that illustrate your educational experiences at college, which can include college life (academic engagement, faculty contact, student motivation, career development, financial issues, student values, social integration and involvement, and overall satisfaction) and any other external factors that may have an impact on their college experience (family, work, friends, etc.).

As a participant in this study, I will ask you to keep a journal of your reflections on the photographs you have chose to take for a one-week period. To insure as much accuracy as possible, please refer back to your pictures on the provided digital camera in the notebook provided.

At the conclusion of the one-week period we will sit down together to review the photographs and conduct a short interview.

Please take a few minutes at the end of each day to expand upon the notes you jotted down earlier in the day.

Suggestions for journaling:

- Be as specific as possible when writing

- The main focus is the description of the experience

- Write about how you felt about this experience - those involved, yourself, and the environment 


\section{Appendix F}

\section{Photography Consent}

I, , hereby grant permission to Alex Tuel to use photographs and/or digital images taken by me for use in the dissertation project titled: The Nontraditional Community College Student: A Phenomenological Approach to the Educational Experience. Additionally, I grant permission to Alex Tuel to use photographs and/or digital images taken by me for use in any future publications.

I, , herby grant permission to Alex Tuel to use photographs and /or digital images taken of me for use in the dissertation project titled: The Nontraditional Community College Student: A Phenomenological Approach to the Educational Experience. Additionally, I grant permission to Alex Tuel to use photographs and/or digital images taken of me for use in any future publications

I understand that no personal information, such as names, will be used in any publications.

I acknowledge that I will not receive any compensation for the use of the pictures taken during the course of this study.

Participant's Name:

Address:

Telephone Number:

Signature:

Date: 


\section{Appendix G}

Modified Stevick-Colaizzi-Keen Method of Analysis of Phenomenological Data

1. Using a phenomenological approach, obtain a full description of your own experiences of the phenomenon.

2. From the verbatim transcript of your experience complete the following steps:

a. Consider each statement with respect to significance for description of the experience.

b. Record all relevant statements

c. List each nonrepetitive, nonoverlapping statement. These are the invariant horizons or meaning units of the experience

d. Relate and cluster the invariant meaning units into themes

e. Synthesize the invariant meaning units and themes into a description of the textures of the experience. Include verbatim examples

f. Reflect on your own textural description. Through imaginative variation, construct a description of the structures of your experience

g. Construct a textural-structural description of the meanings and essences of your experience.

3. From the verbatim transcript of the experiences of each of the co-researchers, complete the above steps, a through $g$

From the individual textural-structural description of all participants' experiences, construct a composite textural-structural description of the meanings and essences of the experience, integrating all individual textural-structural descriptions into a universal description of the experience representing the group as a whole (Moustakas, 1994, p. 122). 


\section{Appendix H}

\section{Significant Statements}

- As far back as I could remember, I would rather take a pill at the doctors than go to school

- I don't think my high school prepared me, certainly not for college. It was a different day and time where the girls were not expected to go to college

- I have a study area in my living room

- I can't be responsible of every dinner or dish so I have to let some things go

- I'm sure my grades would be a lot better if I was isolated for 3 days a week, but in my stage in life its not really an option

- I see other students as insignificant. I see it as a waitressing job, students don't have an impact on my grade

- My dad did not see the value in education. His generation did well without a formal education

- Family wanted me to work on the farm after high school

- I'm not involved too much at school. I'm in here and back out

- For the most part, I have been very please with faculty

- I always have something else to worry about...family or my job

- It is how I was raised. There is a time to screw off but at school you are there to accomplish something

- The enrollment process was easy. The staff that helped with my VA material was great

- The learning environment is great because of the small size. It gives students a chance for more hands-on experience

- Being out of school for so long, taking the placements tests were stressful

- My advisor helped a lot. She spent time finding times and days that fit my schedule

- After high school, I met my husband. He did not want me to go to college, but I always wanted to go.

- I chose to save my marriage rather than pursue education and a high level job

- Getting my college degree has always been a bucket list for me

- I tried a bigger college once, but could never get any one-on-one help

- I am not looking for socialization

- Meeting staff and faculty who go above and beyond to help

- I'm the only one in my family that got a diploma

- I have 3 kids, a husband and a job...so baseball is not important

- Only until I joined the military did I graduate high school

- I was just not equipped educationally

- I did not know how to study

- It has been a struggle - finances, my daughter, my wife not working

- Having a boyfriend and 3 kids in the house...it is really hard to isolate yourself

- I have a lot more responsibility than most college kids

- I got married and bought a farm, college was not an option

- The times for classes are a struggle with my job and family 
- It has been a huge challenge because I have to try and find classes that are later in the day and that is a struggle with work

- I can't tell my kids no I'm not going to read you a bedtime story

- One day my child was leaving the house and she looked very happy. I said where are you going? She said she was going to school and I thought to myself, if she can go to school and be happy, so can I

- I'm doing this for personal reasons. I get to gain knowledge that I wouldn't otherwise

- Sometimes I feel envious of traditional students. If my only job was to go to school, I would get a lot more out of it

- This is just a job. Get in and get out. It is a stepping stone to better opportunities

- Completion is my goal. If I have a class with some students and I don't see them again, that is ok

- I want the accomplishment of the AA

- Traditional students think they have it tough. I had 3 kids with no medication... what I'm doing now is much harder

- I don't want to ask people if they want fries with that my whole life

- I always finish goals that I start

- I want a better future for my family

- I don't want to be labeled a loser. I want to stick to this to the end 